\title{
ANNUAL STATUS REPORT on the
}

\section{Uranium Mill Tailings Remedial Action Program}

December 1980

Prepared in response to the requirements of Section 114(a) to Public Law 95-604 U.S. Department of Energy by Assistant Secretary for Nuclear Energy 


\section{DISCLAIMER}

This report was prepared as an account of work sponsored by an agency of the United States Government. Neither the United States Government nor any agency Thereof, nor any of their employees, makes any warranty, express or implied, or assumes any legal liability or responsibility for the accuracy, completeness, or usefulness of any information, apparatus, product, or process disclosed, or represents that its use would not infringe privately owned rights. Reference herein to any specific commercial product, process, or service by trade name, trademark, manufacturer, or otherwise does not necessarily constitute or imply its endorsement, recommendation, or favoring by the United States Government or any agency thereof. The views and opinions of authors expressed herein do not necessarily state or reflect those of the United States Government or any agency thereof. 


\section{DISCLAIMER}

Portions of this document may be illegible in electronic image products. Images are produced from the best available original document. 
Printed in the United States of America

$$
\text { Available from }
$$

National Technical Information Service

U.S. Department of Commerce

5285 Port Royal Road

Springfield, VA 22161

NTIS price codes

Printed Copy: $\quad \$ 14.00$

Microfiche Copy: $\$ 3.50$ 
I has been reproduced $\mathrm{ram}$ the best avallable croy in perinit tire hroadest possible availaubitity.

\section{MASTER}

\section{ANNUAL STATUS REPORT on the}

\section{Uranium Mill Tailings Remedial Action Program}

December 1980

Prepared in response to the requirements of Section 114(a)

to Public Law 95-604

U.S. Department of Energy by Assistant Secretary for Nuclear Energy

Washington, D.C. 20545
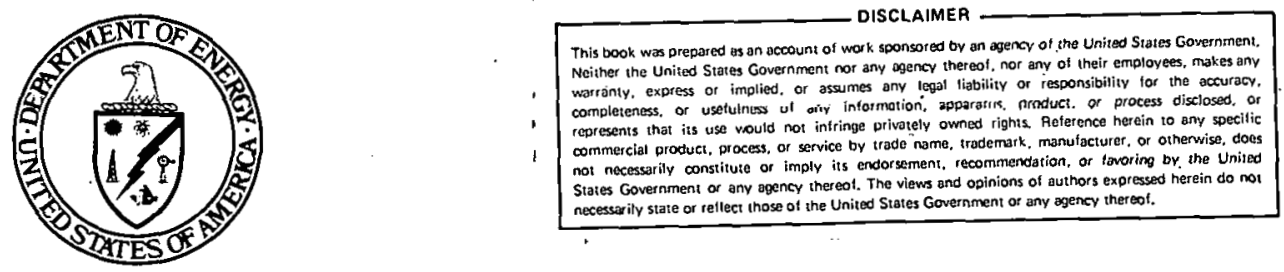
This Second Annual Status Report on the Uranium Mill Tailings Remedial Action (UMTRA) Program has been prepared in fulfillment of the provisions of Section 114 (a) of Public Law 95-604, the "Uranium Mill Tailings Radiation Control Act of 1978."

The purpose, scope, history, requirements, and management organization of the UMTRA Program are summarized in the Introduction. The remainder of the report describes progress made during the past year (FY 1980) and discusses future plans and activities.

In November, 1979, 25 inactive uranium-mill-tailings sites (processing sites) were designated for remedial action by the Assistant Secretary for Environment of the Department of Energy (DOE) under the provisions of Section 102 (a) of the Act. Early emphasis has been on the four highest-priority eites bocause nf their proximity to population centers. These sites are (1) Canonsburg, Pennsylvania, (2) Salt Lake City, Utah, (3) Durango, Colorado, and (4) Shiprock, New Mexico (Navajo Reservation).

During FY 1980, the DOE continued radiological assessments of "vicinity properties," i.e., those properties in the vicinities of designated processing sites that are determined to be contaminated with radioactive materials from such sites as defined in section $102(e)(2)$ of the Act. To date, twenty-five vicinity properties near the Canonsburg site and two such properties near the Salt Lake City site have been designated for remedial action. vicinity properties at these and other sites will continue to be assessed in FY 1981.

A research effort was undertaken during FY 1980 at a major vicinity property, the Mountain States Supply Company in Salt Lake City, to study the effects of heating-and-ventilating-system modification on indoor radon-daughter concentrations.

Among the conditions that must be satisfied before remedial action at a processing site can begin are (1) the execution of a cooperative agreement between DOE and the state or Indian tribe within whose boundaries the processing site is located, (2) where appropriate, the acquisition of the processing site and/or a disposal site pursuant to the provisions of section 104 of the Act, and (3) compliance with the provisions of the National Envi ronmental Policy Act (NEPA).

A cooperative agreement was executed between DOE and the Commonwealth of Pennsylvania during FY 1980. A similar agreement with the State of Utah is expected to be executed in early FY 1981. Further, it is expected that additional cooperative agreements will be negotiated during FY 1981 with the states of Colorado and wyoming and the Navajo Nation.

It is expected that the processing site at Canonsburg, PA (the Canonsburg Industrial Park) will be acquired during FY 1981.

Draft Environmental Impact statements for the four highest-priority sites will be completed during FY 1981. 
Careful planning is needed in order to ensure the timely and effective implementation of remedial actions at the designated processing sites and to integrate the diverse requirements of the UMTRA Program. Consequently, preparation of a comprehensive UMTRA Program Plan and other planning documents has been initiated.

Other program-related activities carried out during FY 1980 include (1) the establishment of a Technology Development program, (2) the development of preliminary Remedial Action Schedules for 23 designated processing sites, (3) the establishment by the states of citizens' advisory task forces in communities near the four highest-priority sites, (4) the solicitation of expressions of interest in tailings reprocessing from private parties, and (5) the initiation of the process of selecting a Technical Assistance Contractor (TAC) and a Remedial Action Contractor (RAC) to carry out remedial actions at the designated processing sites.

Contributions are included in section 12 of shapter II of thic report Erom four illes rederal agencies that are participating in UMTRA program activities--the Environmental Protection Agency (EPA), Nuclear Regulatory Commission (NRC), Department of the Interior (DOI), and Department of Justice (DOJ).

Comments were also invited from affected states and Indian tribes. Their verbatim responses are included in Appendix $F$ of this report. 
I. INTRODUCTION $\frac{\text { Page }}{1}$

1. Purpose and Scope of Report

2. Program History. 2

3. Program Authorization 3

4. Program Management. and Operations 4

II. PROGRAM STATUS 9

1. Designation of Processing Sites 9

2. Designation of Vicinity Properties 13

3. Establishment of Cooperative Agreements 21

4. Promulgation of Standards for Remedial Action 22

5. Acquisition and Disposition of Lands and Materials 23

6. Reprocessing of Residual Radioactive Materials 24

7. National Environmental Policy Act Documentation 25

8. Program Planning 27

9. Remedial Action 29

10. Public Participation 30

11. Interagency Program Activities 31

12. Other Federal Agency Activities 31

13. State/Indian Tribe Activities 38

III. PROGRAM PLANS $\quad 39$

1. Radiological Assessment 39

2. Establishment of Cooperative Agreements 42

3. Acquisition and Disposition of Lands and Materials 42

4. National Environmental Policy Act Documentation 42

5. Program Planning 43

6. Remedial Action 45

IV. PROGRAM FUNDING

$\begin{array}{ll}\text { Appendix A } & \text { Public Law 95-604 } \\ \text { Appendix B } & \text { Model State/DOE Cooperative Agreement } \\ \text { Appendix C } & \text { Summary of EPA Interim and Proposed Standards } \\ \text { Appendix D } & \begin{array}{l}\text { Reprocessing Activities Involving Inactive } \\ \text { Uranium Mill Tailings Piles, Federal Register Notice }\end{array} \\ \text { Appendix E } & \begin{array}{l}\text { Public Participation Program-Lists of Task Force } \\ \text { Members }\end{array} \\ \text { Appendix F } & \begin{array}{l}\text { Input from States and Indian Tribes } \\ \text { Appendix G }\end{array}\end{array}$




\section{FIGURES}

Figure

1

2

3

$4 \mathrm{~A}$

$4 B$

$4 C$

4D
Map of Processing Sites

Uranium Mill Tailings Remedial Action Project Schedule Remedial Action Process Master Schedule

Schedule for Remedial Action - Salt Lake City, UT

Schedule for Remedial Action - Canonsburg, PA

Schedule for Remedial Action - Durango, CO

Schedule for Remedial Action - Shiprock, NM $\underline{\text { Page }}$

10

26

46

47

48

49

50

TABLES

Table 


\section{INTRODUCTION}

1. Purpose and Scope of Report

This report has been prepared in accordance with the requirements of Public Law 95-604, the "Uranium Mill Tailings Radiation Control Act of 1978," enacted November 8, 1978. Section 114 (a) of the Act requires that, beginning on January 1, 1980, and each year thereafter until the project is completed, the Department of Energy (DOE) submit a report to Congress with respect to the status of actions required to be taken by the DOE, Nuclear Regulatory Commission (NRC), Department of the Interior (DOI), Environmental Protection Agency (EPA), and states and Indian tribes under the Act and any amendments to other laws made by this Act.

Title I of the Act authorizes the DOE, in cooperation with the states and Indian tribes within whose boundaries certain inactive deposits of uranium-mill tailings lie, and with persons who own or control these inactive uranium-mill-tailings sites, to provide a program of assessment and remedial action at such sites. The purpose of the remedial action is to stabilize and control these tailings in a safe and environmentally sound manner and to minimize or eliminate the radiation health hazards to the public. The program must include, where appropriate, the reprocessing of tailings to extract residual uranium and other minerals.

The First Annual Status Report of the Inactive Uranium Mill Tailings Remedial Action Program was submitted to Congress by the secretary of Energy on December 28, 1979. That report was prepared by the office of Environment. This Second Annual status Report includes (1) a brief summary of conditions and activities leading to the enactment of legislation for the remedialaction program for inactive uranium-mill-tailings sites, (2) a description of program progress through september 30, 1980, and (3) a forecast of activities to be accomplished during the next fiscal year.

As used in this report, the term "processing site" means any site, including the mill, containing residual radioactive materials at which all or substantially all of the uranium was produced for sale to the Federal 
government and which otherwise satisfies the criteria established in Section $101(6)(A)$ of the Act. The term "vicinity property" is used here to mean any other real property or improvement thereon which is in the vicinity of such a site and which is determined by the DOE, in consultation with the Nuclear Regulatory Commission (NRC), to be contaminated with radioactive materials from such a site, as defined in section $101(6)(B)$ of the Act (see Appendix A) .

\section{Program History}

Much of the uranium ore mined within the United States from the early 1940 s through 1970 was processed for the Manhattan Engineering District (MED) and the Atomic Energy Comnission (AEC) by private companies. When processing operations ceased for the Government and a mill became inactive, large quantities of uranium-mill tailings remained. In the early years, little was known about the effects of the radioactivity on the public.

However, in the course of time research on the effects of low-level radiation progressed, and radiological criteria became more stringent. In 1972 Congress passed Public Law 92-314 (later amended by Public Law 95-236) to provide authority and funds for a cooperative state-Federal program to perform remedial actions on structures in Grand Junction, Colorado, where mill tailings had been used for construction. To date, some 375 structures have been cleaned up under that program; an approximately equal number of structures are awaiting action. A DOE report to Congress in February 1979, "Progress Report on the Grand Junction Uranium Mill Tailings Remedial Action Program" (DOE/EV-0033), provided an analysis of the status of that program.

A second program was initiated in 1972 to perform an initial evaluation of several of the other inactive uranium-mill-tailings sites that had provided uranium exclusively to the Federal government to determine their radiological status and potential health effects on the public. Since that time, considerable effort has been directed towards recovering and reviewing radiological site-status information and records, identifying sites, conducting engineering assessments, and developing legislation to initiate remedial action at inactive uranium-mill-tailings sites. 
In March 1974 the Subcommittee on Raw Materials of the Joint Committee on Atomic Energy (JCAE) of the Congress held hearings on bills that would have provided for $a$ cooperative program between the Federal government and the state of Utah to implement remedial action at the inactive uranium-mill-tailings site in Salt Lake City. The AEC and EPA proposed at the hearings that a comprehensive study be performed of all formerly active uranium mill tailings sites, rather than a piecemeal treatment of the problem. The outcome was an assessment by the AEC in 1974 of the physical conditions of inactive uranium-mill sites located in eight western states; this work was carried out in cooperation with the EPA, which also funded part of this work, and the affected states. Preliminary engineering evaluations of many of these sites commenced in 1975 and were completed in 1977 by the Energy Research and Development Administration, the successor to the AEC. As a result, it was concluded that some form of remedial action was required at most of these sites in order to alleviate potential public health hazards.

\section{Program Authorization}

In April 1978 DOE submitted proposed legislation to Congress that would establish a program to stabilize and control the mill tailings in a safe and environmentally sound manner. Hearings on the proposed legislation began in June 1978 in conjunction with similar bills introduced in the senate and House of Representatives.

As a result of these hearings, Public Law 95-604 (Appendix A) was enacted on November 8, 1978: In enacting this legislation, Congress determined that the Federal government should perform remedial actions at inactive uranium-mill-tailings sites located on private property because the then-existing NRC regulatory authorities were inadequate to require private remedial action on these properties. Title I of the Act authorizes DOE, with the affected states, Indian tribes, and persons who own or control inactive uranium-mill tailings, to establish assessment and remedial action programs at designated inactive uranium-mill-tailings sites. Title I of the act further stipulates that DOE will meet radiation standards to be promulgated by EPA for this purpose. The act specifically mandates that remedial action is to be carried out within the 7-year period following the 
promulgation of such standards by EPA. Further, DOE will finance 90 percent of the remedial-action costs, and the affected states will be required to pay the remaining costs from non-Federal funds. An exception to this requirement are those sites on Indian tribal lands, where 100 percent of the costs for remedial action will be borne by the Federal Government.

\section{Program Management and Operations}

\subsection{Major DOE Programmatic Responsibilities}

The Uranium Mill Tailings Remedial Action (UMTRA) Program is being implemented in the DOE by the Office of the Assistant secretary for Nuclear Energy (ASNE) and by the Office of the Assistant Secretary for Environment (ASEV). In keeping with DOE's intent to consolidate the management of all nuclear-waste-management programs, responsibility for the conduct of remedial actions at the inactive uranium-mill-tailings sites was transferred during FY 1979 from ASEV to ASNE. With this transfer, the separation of responsibilities can be characterized as follows:

- ASNE Technology development and testing; determination of the feasibility of remilling residual radioactive materials; preparation of NEPA documents; negotiation of cooperative agreements with the states and Indian tribes; acquisition of properties; implementation of remedial actions; and other activities necessary to fulfill the intent of Public Law 95-604.

- ASEV Designation of processing sites and vicinity properties for remedial action; participation in the determination of remedial-action projects; determination of the need for and the potential extent of cleanup required; conduct of radiological screening and aerial, ground, and post-remedial-acion radiological surveys; review and approval of NEPA 
documents prepared by ASNE; operational safety and environmental overview, including independent audits; certification of compliance of final conditions with applicable Federal, state, and local standards.

\subsection{Program Organization}

Within the Office of the Assistant Secretary for Nuclear. Energy (ASNE), the Remedial Action Program Office of the Office of Nuclear Waste Management is responsible for program management with appropriate participation by the office of the Assistant Secretary for Environment (ASEV). Responsibility for conducting remedial actions at inactive uranium-mill-tailings sites has been delegated to the Uranium Mill Tailings Remedial Action (UMTRA) Project Office, which has been established at the Albuquerque Operations office. Specifically, the Project office is responsible for the following activities:

1. Coordinating project activities with Indian tribes, state and local government officials, and the public.

2. Negotiating, executing, and administering cooperative agreements:

3. Developing the technology for disposition and stabilization of the mill tailings.

4. Managing the preparation of NEPA documents.

5. Managing the planning and analysis effort leading to the selection of remedial-action options, engineering of remedial-action designs, accomplishment of onsite remedial activities, and licensing of final-disposal sites. 
6. Contracting for the execution of remedial actions at processing and final-disposal sites.

Within the Office of the Assistant Secretary for Environment, responsibility for the conduct of radiological assessment, overview, and certification operations has been assigned to the Environmental and Safety Engineering Division (ESED) of the Office of Environmental Compliance and Overview, ASEV. The ESED is supported through the National Laboratories and other contractors to accomplish its program responsibilitities.

\subsection{Other DOE Coordinating Activities}

Support for the remedial-action program involves other major offices within DOE including the Office of General Counsel, the office of Administration, and the Office of Procurement and Contract Management.

\subsection{Other Federal Agency Responsibilities}

Public Law 95-604 directs the EPA to promulgate standards of general application for remedial actions at inactive uranium-mill-tailings sites. No remedial action is to be undertaken at a processing site prior to the promulgation of these standards. In addition, EPA provides advice to DOE on assessing hazards and establishing priorities at the designated sites.

Public Law 95-604 amends the Atomic Energy. Act of 1954 to give the NRC statutory authority to directly license and promulgate regulations over the tailings or wastes produced by the extraction or concentration of uranium or thorium from any ore processed primarily for its source-material content. The DOE is required to consult with NRC on the designation of processing sites and vicinity properties. In addition, NRC concurrence is required on (1) any cooperative agreements between 
DOE and the affected states, or where applicable, the Indian tribe on whose land the processing site is located; (2) the acquisition of all processing and disposal sites; and (3) the selection and performance of remedial actions.

For processing sites located on tribal lands, DOE, in coordination with the Department of the Interior (DOI), is authorized to enter into a cooperative agreement with the affected Indian tribe to perform the necessary remedial action. When necessary or appropriate to consolidate the radioactive wastes removed from sites under any state or tribal agreements or when otherwise necessary for the permanent disposition and stabilization of radioactive wastes, the DOI may, under the provisions of the Act, make available for such purposes public lands that it administers.

For each processing site designated by DOE as requiring remedial action under the provisions of the Act, the Department of Justice (DOJ) is to conduct a study to-determine the identity of any persons (other than the United States, a state, or Indian tribe) who owned, operated, or controlled the site before November 8, 1978, and their legal responsibility, under any law or rule of law, for reclamation or other remedial action with respect to the specific site under study. The DOJ is to publish the results of the study and provide copies to Congress. Based on the study, the Attorney General shall, if he deems it appropriate and in the public interest, take the necessary action under any provision of law in effect at the time the uranium was produced at the site to require payment of all or any part of the costs incurred by the U.S. for remedial action.

\subsection{States and Indian Tribes Responsibilities}

Public Law 95-604 further provides for the full participation in. the remedial-action program of the affected state or Indian tribe under whose jurisdiction a processing site is located. The affected states 
and Indian tribes are to participate in the following program activities: consultation with DOE on designation of processing sites, entering into cooperative agreements with DOE, acquisition and disposition of lands and materials, and approval of remedial-action plans. In addition, the affected states have the responsibility for identifying candidate disposal sites and for acquiring sites as required for remedial-action purposes including the disposition of the residual radioactive materials. Each state or tribe is to fully participate or consult in the selection and performance of remedial actions. 


\section{PROGRAM STATUS}

This chapter describes the progress made during the past year (FY 1980), discusses the present status of the remedial-action program, and outlines the methods for accomplishing the program goals. Information for the first three sections and portions of others were provided by the ASEV.

\section{Designation of Processing sites}

In late 1979, as described in the First Annual status Report, 25 processing sites were designated (Figure 1) and site priorities established (Table 1). There are nine high-priority sites, although early emphasis has been placed upon four of these sites because the radiation health $r$ isks are greatest at these sites. These four sites are

- Canonsburg, Pennsylvania

- Salt Lake City, Utah

- Durango, Colorado

- Shiprock, New Mexico (Navajo Nation).

The remaining high-priority sites where remedial action will begin as soon as feasible are

- Gunnison, Colorado

- Grand Junction, Colorado

- Rifle, Colorado (2 sites)

- Riverton, Wyoming. 


\section{LOCATION - UMTRAP SITES}

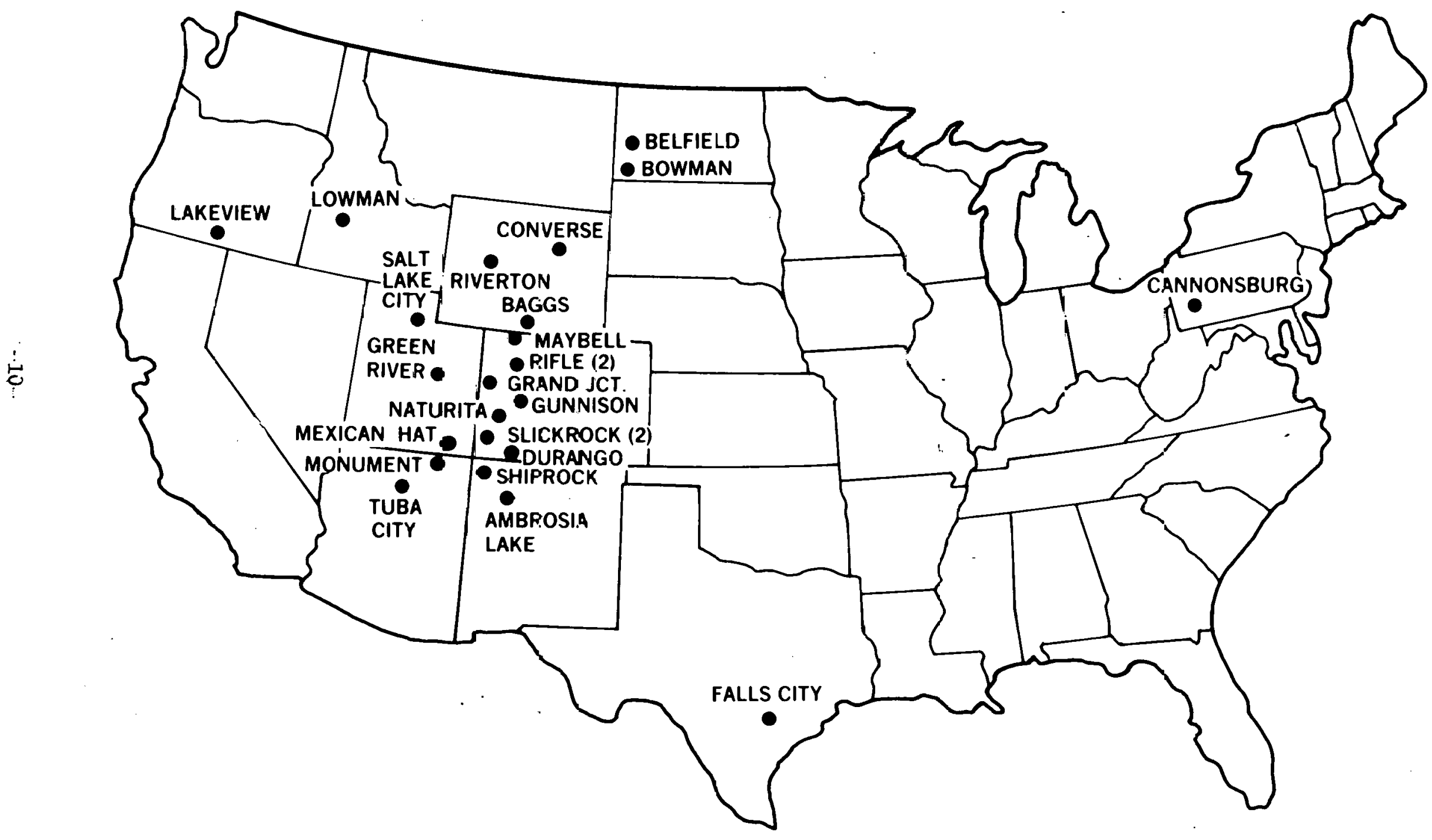

FGURE 1 
TABLE 1

Processing Sites and Priorities

\begin{tabular}{|c|c|c|c|}
\hline State & Location & Processing Site & Priority \\
\hline Arizona & $\begin{array}{l}\text { Monument Valley } \\
\text { Tuba City }\end{array}$ & $\begin{array}{l}\text { Monument Valleya } \\
\text { Tuba City }\end{array}$ & $\begin{array}{l}\text { Low } \\
\text { Medium }\end{array}$ \\
\hline Colorado & $\begin{array}{l}\text { Durango } \\
\text { Grand Juncton } \\
\text { Gunn ison } \\
\text { Maybell } \\
\text { Naturita } \\
\text { Rifle } \\
\text { Rifle } \\
\text { Slick Rock } \\
\text { Slick Rock }\end{array}$ & $\begin{array}{l}\text { Durango } \\
\text { Grand Junction } \\
\text { Gunnison } \\
\text { Maybell } \\
\text { Naturita } \\
\text { New Rifle } \\
\text { Old Rifle } \\
\text { Slick Rock (NC) } \\
\text { Slick Rock (UC) }\end{array}$ & $\begin{array}{l}\text { High } \\
\text { High } \\
\text { High } \\
\text { Low } \\
\text { Medium } \\
\text { High } \\
\text { High } \\
\text { Low } \\
\text { Low }\end{array}$ \\
\hline Idaho & Lowman & Lowman & Low \\
\hline New Mexico & $\begin{array}{l}\text { Ambrosia Lake } \\
\text { Shiprock }\end{array}$ & $\begin{array}{l}\text { Ambrosia Lake } \\
\text { Shiprock }\end{array}$ & $\begin{array}{l}\text { Medium } \\
\text { High }\end{array}$ \\
\hline North Dakota & $\begin{array}{l}\text { Belfield } \\
\text { Bowman }\end{array}$ & $\begin{array}{l}\text { Belfield } \\
\text { Bowman }\end{array}$ & $\begin{array}{l}\text { Low } \\
\text { Low }\end{array}$ \\
\hline Oregon & Lakevi ew & Lakeview & Medium \\
\hline Pennsylvania & Canonsburg & Canonsburg & High \\
\hline Texas & Falls City & Falls City ${ }^{b}$ & Medium \\
\hline
\end{tabular}


TABLE 1--Continued

\begin{tabular}{|c|c|c|c|}
\hline State & Location & Processing Site & Priority \\
\hline Utah & $\begin{array}{l}\text { Green River } \\
\text { Mexican Hat } \\
\text { Salt Lake City }\end{array}$ & $\begin{array}{l}\text { Green River } \\
\text { Mexican Hat } \\
\text { Salt Lake City }\end{array}$ & $\begin{array}{l}\text { Low } \\
\text { Medium } \\
\text { High }\end{array}$ \\
\hline Wyoming & $\begin{array}{l}\text { Baggs } \\
\text { Converse County } \\
\text { Riverton }\end{array}$ & $\begin{array}{l}\text { Baggs }^{b} \\
\text { Converse County } \\
\text { Riverton } c\end{array}$ & $\begin{array}{l}\text { Low } \\
\text { Low }\end{array}$ \\
\hline
\end{tabular}

aprocessing site on tribal lands within the boundaries of the Navajo reservation.

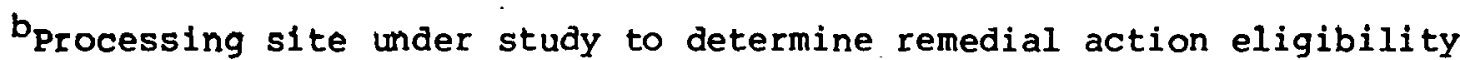
under the provisions of Section $101(6)$ (A) of Public Law 95-604.

${ }^{c}$ Processing site located on private property within the boundaries of the Wind River Indian Reservation. 
2. Designation of Vicinity Properties

2.1. Radiological Assessments

Under the provisions of Section $102(e)(2)$ of the Act, the Environmental and Safety Engineering Division of the Office of Environment is developing radiological assessment data on any other real property or improvement thereon outside the boundaries of the 25 designated processing sites that is determined by the ASEV, in consultation with the Nuclear Regulatory Commission, to be contaminated with residual radioactive materials derived from such sites. This radiological-characterization program is being conducted on a site-by-site basis and incorporates the results of gamma-radiation screening surveys of properties near inactive uranium-mill-tailings sites that were conducted in 1972 by the Environmental Protection Agency. The initial gamma-radiation screening surveys were the first assessment of the possible extent of migration or removal of residual radioactive materials from the processing sites onto properties in their vicinity. Some of the findings of these early surveys are summarized in Table 2. Since 1972, some state agencies, such as those in Colorado and Utah, have continued to collect radiological-assessment data to further identify the presence of residual radioactive materials outside the boundaries of processing. sites under their jurisdiction. However, in some instances, the Environmental and. Safety Engineering Division has determined that more extensive radiological assessments are required to thoroughly define the extent of migration or removal of residual radioactive materials to vicinity properties.

The Environmental and Safety Engineering Division's radiologicalassessment program for vicinity properties consists of aerial and mobile-ground-unit gamma-radiation surveys and comprehensive radiological surveys of individual properties. These radiological-assessment activities are being supplemented by assistance from the affected state and local governments, individual property owners, and the general public. During FY 1980, the Environmental and 
TABLE 2

Summary of Environmental Protection Agency Initial Gamma Screening

Survey fesults of Vicinity Properties

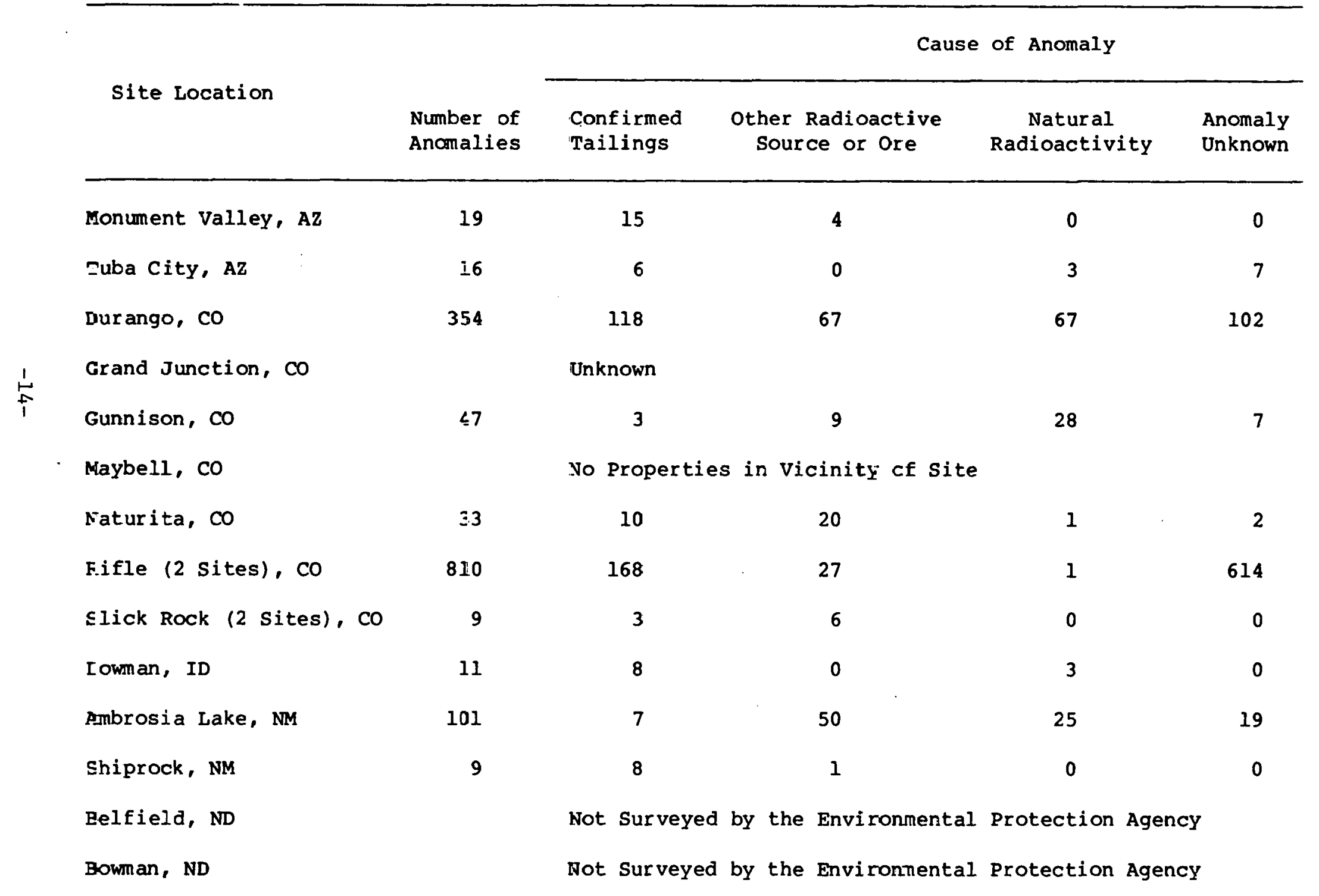


TABLE 2--Continued

\begin{tabular}{|c|c|c|c|c|c|c|}
\hline \multirow{2}{*}{ Site Location } & \multirow[b]{2}{*}{$\begin{array}{l}\text { Number of } \\
\text { Anomalies }\end{array}$} & \multicolumn{5}{|c|}{ Cause of Anomaly } \\
\hline & & $\begin{array}{l}\text { Confirmed } \\
\text { Tailings }\end{array}$ & \multicolumn{2}{|c|}{$\begin{array}{l}\text { Other Radioactive } \\
\text { Source or Ore }\end{array}$} & $\begin{array}{c}\text { Natural } \\
\text { Radioactivity }\end{array}$ & $\begin{array}{l}\text { Anomaly } \\
\text { Unknown }\end{array}$ \\
\hline Lakeview, OR & 18 & 0 & & 2 & 10 & 6 \\
\hline Canonsburg, PN & & \multicolumn{2}{|c|}{ Not Surveyed by the } & Envi ronmental & \multicolumn{2}{|c|}{ Protection Agency } \\
\hline Falls City, TX & 5 & 2 & & 0 & 3 & 0 \\
\hline Green River, UT & 23 & 1 & & 14 & 1 & 7 \\
\hline Mexican Hat, UT & 5 & 0 & & 5 & 0 & 0 \\
\hline Salt Lake City, UT & 230 & 70 & & 15 & 76 & 69 \\
\hline Baggs, WY & & \multicolumn{5}{|c|}{ Not Surveyed by the Environmental Protection Agency } \\
\hline Converse County, wY & 28 & 13 & & 10 & 3 & 2 \\
\hline Riverton, $W Y$ & 85 & 14 & & 15 & 33 & 23 \\
\hline
\end{tabular}


Safety Engineering Division's efforts were focused on the processing sites located in Canonsburg, Pennsylvania (former Vitro Rare Metals Plant), Salt Lake City, Utah (Vitro site), and Lowman, Idaho.

\subsubsection{Canonsburg, Pennsylvania}

Investigations to determine the extent of migration or removal of radioactive materials from the designated Canonsburg processing site to vicinity properties began in 1978 . The results of an aerial radiological survey conducted during April 1978 provided evidence of the migration of radium-bearing materials from the processing site into the surrounding communities of Canonsburg, strabane, and Houston, Pennsylvania. A subsequent gamma-radiation survey with mobile ground units were followed by a pilot survey program to assess the radiological status of selected properties in the community of strabane, Pennsylvania. A detailed radiological assessment of properties identified during the initial aerial survey and a subsequent survey with mobile ground units were conducted for the office of Environment by the Oak Ridge National Laboratory. The results of the pilot survey study were provided to all affected property owners during July 1979; these included the locations of elevated radiation levels, the significance of the findings, and where appropriate, Departmental recommendations regarding personal exposure to the areas of elevated radiation.

A second, more extensive aerial survey conducted in August 1979 provided additional evidence of residual radioactive materials in the Boroughs of Canonsburg and Houston, Pennsylvania, which lie to the north and west of the processing site, respectively. Data from the aerial survey of August 1979 and from previous surveys were used to guide an intensive radiological assessment of private properties in the communities of Canonsburg, strabane, and Houston, Pennsylvania, which were believed to contain residual radioactive material derived from the Canonsburg site; this work was initiated in April 1980. Initially, a mobile ground unit was used to identify specific properties or locations 
that exhibited radioactivity levels above background for the local area: Local government and public participation was solicited by the Environmental and Safety Engineering Division staff through daily communications to identify additional areas believed to contain residual radioactive materials from the Canonsburg site. All identified properties were comprehensively surveyed during the period of April through August 1980 .

\subsubsection{Salt Lake City, Utah}

The Environmental Protection Agency's initial gamma-screening surveys of the salt Lake City area in 1972 disclosed some 230 . gamma-radiation anomalies, i.e., locations at which the gamma-radiation levels exceed those that would be expected from background radiation alone (Table 2). The presence of uranium-mill tailings was identified as the source of the radiation anomalies at approximately 70 of the 230 locations. The tailings had either migrated from the processing site by natural wind and water action or had been removed for use in construction-related projects.

The results of the Environmental and Safety Engineering Division's aerial radiological survey of a 36-square-mile area in the vicinity of the processing site were used by the state of utah and Salt Lake City County authorities to verify those properties previously identified by the Environmental Protection Agency's gamma-screening survey and to identify any other properties that might contain radioactive materials derived from the Salt Lake City processing site. Since the first aerial survey indicated radiation anomalies that had not been detected by ground-based gamma-radiation surveys, a second aerial survey was conducted that covered an additional 158 square miles. Preliminary results indicated about 10 locations in the new area that might contain tailings. 


\subsubsection{Other Radiological Assessment Activities}

In addition to the aerial radiological surveys of the Canonsburg, Pennsylvania, and Salt Lake City, Utah, areas, aerial radiological surveys were conducted during FY 1980 at all of the high-priority sites (Table 1) and Mexican Hat, Utah, and Monument Valley, Arizona.

An extensive radon-monitoring program was initiated at Canonsburg, Pennsylvania, during February 1980. The purposes of the program are to (1) determine the effect of current radon releases from uranium-mill-tailings piles at designated processing sites on the radon concentrations in the surrounding enviroment; (2) monitor changes in the radon emissions around the site during remedial actions; and, (3) verify that remedial actions taken at a particular site are effective. Currently, there are a total of 50 radon monitors installed around the Canonsburg site.

In addition to the above-discussed radiological surveys and radon-monitoring program, post-remedial-action surveys of each site and associated vicinity properties are to be conducted by the office of Enviroment upon completion of remedial actions by the office of Nuclear Energy. These surveys are to characterize the radiological environment for comparison with pre-remedial-action levels and general standards as promulgated by the Environmental Protection Agency. At inactive sites, two categories of remedial action are possible:

- stabilization of the tailings pile at its current location.

- Removal of the tailings pile to a new location (disposal site) and stabilization. 
In either case, post-remedial-action surveys are to be conducted as part of a program to determine whether final conditions are in compliance with applicable standards and criteria. If a tailings pile is moved to a new location (offsite disposal), post-remedial-action surveys will be conducted at the processing and disposal sites, and transportation routes will be monitored.

\subsection{Properties Designated in FY 1980}

Under the provisions of Section $102(\mathrm{e})(2)$ of the Act and the Secretary of Energy's subsequent delegation of authority on November 8 , 1979, the Assistant Secretary for Enviroment is authorized to designate for remedial action those properties in the vicinity of the 25 designated processing sites containing residual radioactive materials from such sites. In developing the initial recommended vicinity-property designations, which included the radiological characterization of such properties, the Office of Environment consulted with the Nuclear Regulatory Commission, the Enviromental Protection Agency, the affected states, and local government officials. Public participation was encouraged through daily written and oral correspondence. Meetings were held in the affected communities when determined by state and local officials to be of value in the vicinity-property-designation process. The Assistant Secretary for Enviroment initially designated for remedial action 25 vicinity properties in Canonsburg, Pennsylvania, and two in Salt Lake City, Utah. They have been referred to the Assistant Secretary for Nuclear Energy for appropriate action. State and local government officials and the affected property owners were informed of these initial property designations.

The Environmental and Safety Engineering Division is continuing to develop radiological assessment data on other properties outside the 
boundaries of the Canonsburg and Salt Lake City processing sites as well as. the remaining 23 designated processing sites. Participating in this activity are representatives of the affected state and local governments, property owners, and the general public. As vicinity properties are nominated, identified, and evaluated in consultation with the Nuclear Regulatory Commission and Environmental protection Agency, they will be designated by the Assistant Secretary for Environment and incorporated into the overall remedial-action program by the office of Nuclear Energy.

2:3. Establishment of Recommended Vicinity-Property Priorities.

The Office of Environment has assessed the potential health effects from the residual radioactive material at the 27 designated vicinity properties associated with the processing sites in Canonsburg, Pennsylvania, and Salt Lake City, Utah. To be in consonance with the priorities that were established for the 25 designated processing sites on November 8, 1979, the Office of Environment has used a ranking of high, medium, and low categories in recommending remedial-action priorities for vicinity properties. 


\section{Establishment of Cooperative Agreements}

After notifying the governors of each of the ten affected states and the Navajo Tribe on December 7, 1979, of the designation of processing sites within their areas of jurisdiction and establishment of remedial action priorities, the Secretary of Energy was authorized to enter into cooperative agreements with the affected states and Indian tribes. This authority is provided under the provisions of sections 103 and 105 of the Act.

As was reported to the Congress in the First Annual status Report, a Sample Cooperative Agreement was developed by the Department of Energy in consultaton with the Nuclear Regulatory Commission and provided to the individual states and Navajo Nation for comments. In addition, an Appendix to the Agreement was developed in order to provide specific guidance to the state on the acquisition of property, to provide payment, closeout, and other procurement procedures for the implementation of the agreement, and to include certain procurement provisions which will apply if the state procures supplies, equipment, construction, or services under the agreement. During September, 1980, a cooperative agreement (and Appendix) was consummated between the Department of Energy and the Commonwealth of Pennsylvania with the concurrence of the NRC. It is expected that a similar agreement will be consummated in the near future between the Department and the state of Utah for the Salt Lake rity site. A model state DOE Cooperative Agreement developed by the Office of General Counsel is included in Appendix B. 


\section{Promulgation of Standards for Remedial Action}

In April 1980 the Environmental Protection Agency, under the provisions of Section 206 of Public Law 95-604, published proposed and interim standards for cleanup activities involving structures and open lands. In the latter category are included processing sites from which tailings are removed and vicinity properties contaminated with radioactive materials derived from the processing sites.

The EPA expects to issue proposed disposal standards and an Environmental Impact statement covering the cleanup and disposal standards in November 1980. See the section of this report covering other Federal Agency Activities-EPA, for further details, 


\section{Acquisition and Disposition of Lands and Materials}

Each cooperative agreement between DOE and an affected state will require that the state, where appropriate, acquire any designated processing site, including, where appropriate, any interest therein. In addition, if the DOE, with the concurrence of NRC, determines that the removal of the residual radioactive material from a processing site is appropriate, then the cooperative agreement is to provide that the state will acquire the land to be used as a disposal site for the permanent disposition and stabilization of such residual radioactive materials in a safe and environmentally sound manner. However, acquisition by the state shall not be required if, in order to consolidate or otherwise permanently dispose of and stabilize residual radioactive materials, it is necessary or appropriate for the DOE to acquire land for such purposes under the provisions of Section 106 of the Act. Where the DOE determines that the removal of residual radioactive materials from a processing site on Indian lands is warranted, then the DOE is to provide, in accordance with other applicable provisions of the law, a site or sites for the permanent disposition and stabilization of such materials.

Tn anticipation of a determination by DOE that the mill tailings at Salt Lake City, Canonsburg, and Durango will have to be moved, the states of Utah and Colorado and the Commonwealth of Pennsylvania have been engaged in searches for alternative disposal sites. The Division of Environmental Health of the State of Utah has recommended sites for the disposal of the Salt Lake City tailings; these recommendations are awaiting final approval by the Governor. The DOE has been advised by the Commonwealth of Pennsylvania that candidate disposal sites for the Canonsburg tailings have been tentatively identified. The Colorado Department of Health is presently engaged in a disposal-site-selection process for the Durango tailings. See Appendix $F$ for details of state activities. 


\section{Reprocessing of Residual Radioactive Materials}

Under the provisions of Section 108 (a) (1) of Public Law 95-604, the Secretary of Energy is to request, before undertaking any remedial action at a designated site, expressions of interest from private parties regarding the remilling of residual radioactive materials at the site. On receipt of any expression of interest, DOE is to evaluate the mineral concentration of the residual radioactive materials at each designated processing site to determine whether, as a part of any remedial-action program, the recovery of minerals is practicable. In addition, any person permitted to recover such minerals is to pay to DOE a share of the net profits derived from such recovery, as determined by DOE. Such a share is not to exceed the total amount paid by DOE for carrying out a remedial action at a designated site.

In accordance with these provisions, letters asking for expressions of interest in reprocessing were sent to site owners by DOE in April 1980. AlI owners who responded expressed interest either in reprocessing or in sharing in the profits if DOE or other parties should reprocess. Further, expressions of interest in reprocessing by qualified private parties were solicited in (1) the Federal Register (Appendix E), (2) the Commerce Business Daily, and (3) a DOE press release. In response, 11 companies expressed general interest, and a twelfth company expressed interest in one particular site, Falls City, Texas.

DOE intends to solicit specific proposals for reprocessing at individual sites from those who responded to the above requests for expressions of interest. Decisions on whether to reprocess at the individual sites will be based on mineral assays of the tailings to be obtained by the DOE, an evaluation of the economics of proposed reprocessing operations, and the compatibility of any specific proposals with planned remedial actions. 


\section{National Environmental Policy Act Documentation}

Before any remedial action is initiated at a processing site the requirements of the National Environmental Policy Act of 1969 (NEPA) must be complied with by DOE. The Office of Environment will review and approve NEPA documents and the associated site-specific remedial-action plans that describe the schedule and nature of the proposed remedial action for each processing site.

A draft NEPA Implementation Plan including tentative schedules for preparation of Environmental Assessments (EAs) and Environmental Impact Statements (EISs) was prepared to assist the UMTRA Project office in scheduling and guiding NEPA-related activities; ancillary documents to accompany the planning documents were also prepared and submitted for approval. They are (1) guidelines for scope and content of UMTRAP EA's, guidelines for scope and content of UMTRAP EISs, and (3) guidelines for format and style of UMTRAP environmental documents.

Because the NRC is to be a cooperating agency in the NEPA process, coordination of NEPA-related activities with the NRC was initiated. Informal agreements between the DOE and the NRC were made concerning (1) the NRC's role in formulating alternatives for remedial action that affect EIS alternatives, and (2) the NRC's role in reviewing environmental documents.

During FY 1980 arrangements were made to prepare Environmental Impact Statements for the four highest-priority sites. Since 1979, data-gathering and analyses of alternatives for remedial action have been carrled out at the Canonsburg site. It is expected that this work will be extended and a draft EIS prepared by July 1981. This date is contingent upon the nomination of final disposal sites by the state. Similar work is being initiated at the sites at Salt Lake City, Utah, Durango, Colorado, and Shiprock, New Mexico. The draft EISs for these sites should be completed by late 1981 .

During FY 1979 draft Environmental Assessments were prepared for most medium- and low-priority sites. These EAs are to be revised and updated. 
UMTRA PROJECT PLANNING SCHEDULE

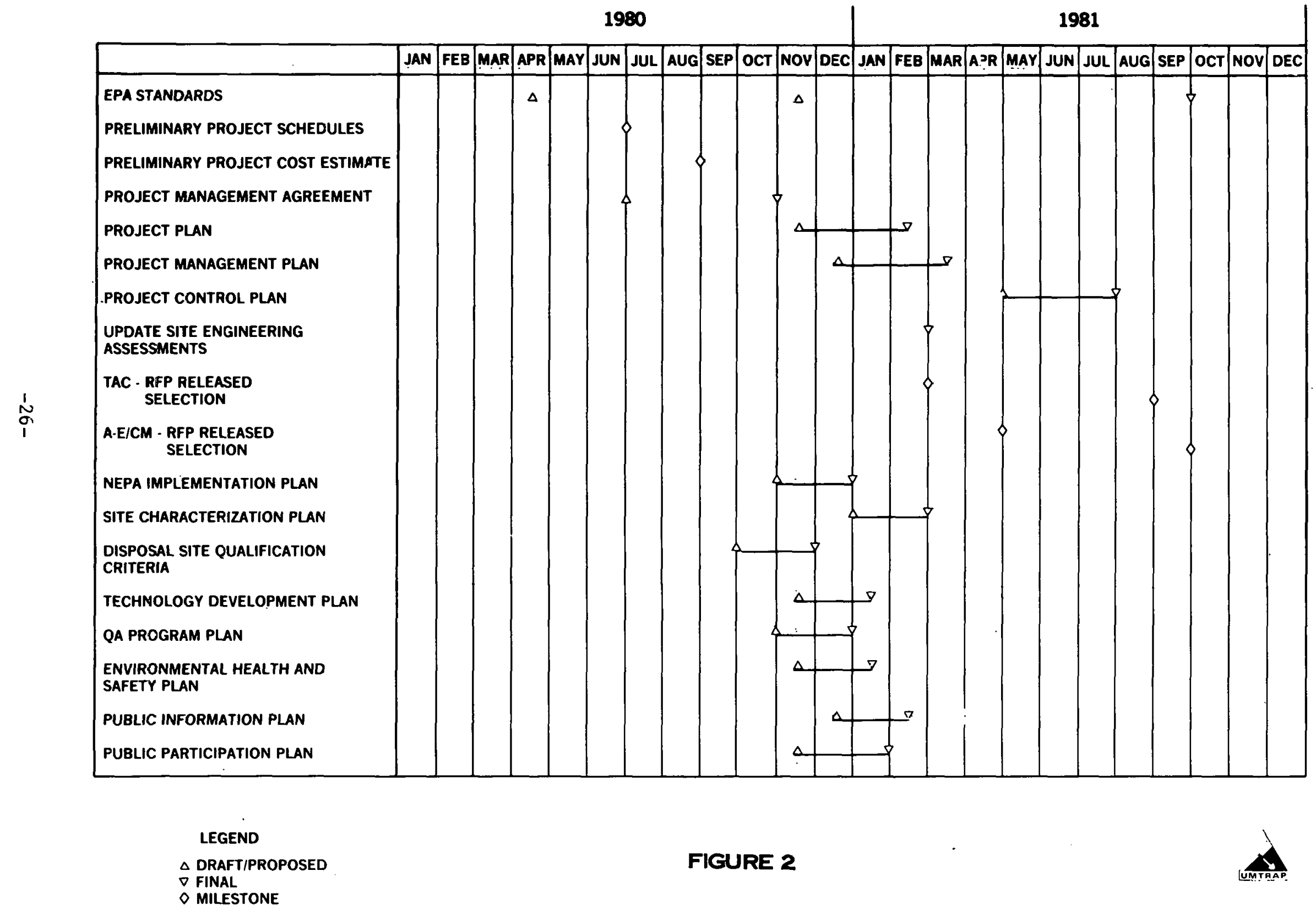




\section{Program Planning}

\subsection{Project Planning}

A schedule showing project-planning activities is given in Figure 2. Preliminary individual schedules for the envisioned remedial actions at twenty-three of the 25 processing sites have also been prepared. Schedules have not yet been developed for the two remaining sites. Schedules have not been prepared for Falls City, Texas, and Baggs, Wyoming, because their designation status is being reconsidered. -

\subsection{Contractor Procurement}

The UMTRA Project Office is in the process of selecting a Technical Assistance Contractor (TAC) and a Remedial Action Contractor (RAC).

Sandia National Laboratories in Albuquerque, New Mexico, is acting as the interim TAC until the selection process is completed; it is expected that a TAC contract will be awarded by the first quarter of FY 1982.

As presently planned, the major responsibilities of the Technical Assistance Contractor will include development and implementation of site characterization programs, preparation of a Remedial-Action Concept Paper for each processing site, preparation of a Remedial-Action Plan for each procesing site, preparation of generic and site-specific remedial-action design critiria, review of detailed designs prepared by the RAC, and conducting maintenance and surveillance activities at sites when remedial actions have been completed.

The engineering and construction (remedial-action) functions are closely related and require careful coordination. For this reason a single contractor to fulfill both functions will be selected. This contractor, the Remedial Action Contractor (RAC), will prepare remedial-action designs, prepare construction schedules, and perform or subcontract for the performance of remedial actions. 
An existing DOE contract with an architect-engineer firm has been modified to enable preparation of engineering assessments, detailed design, and bid packages for remedial actions at the individual vicinity properties in Salt Lake City, Utah. 


\section{Remedial Action}

In FY 1980, a program to develop, analyze, and evaluate potential tailings-disposal and stabilization technologies was initiated. This effort is discussed in section 9.1 below. A system to reduce indoor radon-daughter concentrations in a structure on a vicinity property in salt Lake city that is awaiting final remedial action is discussed in section 9.2.

\subsection{Technology Development}

In early 1980 the Uranium Mill Tailings Remedial Action (UMTRA) Project Office initiated a comprehensive Technology Development program. The program continued some work begun in previous years under other DOE sponsorship and added new tasks to cover previously unexplored facets of the tailings disposal problem. Five areas of technology were identified (1) cover technology, (2) liner technology, (3) measurements and monitoring, (4) tailings conditioning, and (5) basic studies.

Cover technology includes the development of radon seals, moisture barriers, biobarriers (to prevent intrusion by plant roots and burrowing animals), and vegetative covers. Under liner technology, the use of clays and asphalts to prevent the migration of radionuclides and toxic elements and compounds is being investigated. The main purpose of measurements and monitoring is the development, as required by the project, of improved instruments and techniques for measuring low levels of radon, radon daughters, and radium. Tailings conditioning is concerned with the chemical or physical treatment of tailings as a means of enhancing long-term stability and safety. The main effort under basic studies is modeling water and radionuclide transport through the tailings and in the soil that underlies the tailings. 
NRC-sponsored programs in mill-tailings technology, which are conducted in connection with the NRC's regulatory responsibilities under Title II of the Act, are coordinated with the DOE's program to avoid duplication.

\subsection{Research}

The Mountain States Supply Company, a plumbing supply business in Salt Lake City, is built on fill material taken from the vitro tailings pile. In 1979 concentrations of radon daughters exceeding the surgenn General's guidelines were detected inside the buildinq.

As a research effort, a high-capacity heating, ventilating, and air-conditioning system was designed and installed. The system incorporates a previously existing electrostatic precipitator, and is designed so that the volume of fresh air and the volume of circulated air passing through the precipitator can be varied independently. Installation was completed in May 1980. Performance data for the cooling season. (summer months) show that dilution with fresh air is more effective than precipitation in reducing radon-daughter concentration.

The performance of the system during the heating season will be evaluated in FY1981.

\section{Public Participation}

In carrying out the provisions of section III, Title I, of the Act, which includes the designation of processing sites, establishment of priorities for such sites, selection of remedial actions, and execution of cooperative agreements, DOE, EPA, and NRC are to encourage public participation; where appropriate, DOE is to hold public hearings on such matters in the states where processing and disposal sites are located. During the designation of processing sites and the establishment of site priorities, DOE encouraged public participation through the publication of Federal Register notices and press releases. A formal Public Participation Plan for the UMTRA Project is in preparation. 
State and local officials in several communities near high-priority sites have established citizens advisory task forces. These communities are Durango, Salt Lake City, Grand Junction, and Canonsburg. These groups will serve as clearinghouses for the dissemination of information on project progress and plans, and they will also provide an opportunity for local citizens to present their input in the decision-making process. For sites on Navajo land, the tribal chapter having jurisdiction at the site location will function as the advisory body.

\section{Interagency Program Activities}

The DOE has been actively participating with the other responsible federal agencies in implementation of Public Law 95-604. An Interagency Working Group on the implementation of the act was established in 1979 . Participating in this group have been representatives from the EPA, NRC, DOI, and DOJ as well as DOE.

\section{Other Federal Agency Activities}

Under the provisions of Section $114(a)$ of the Act, DOE requested contributions from EPA, NRC, DOI, and DOJ as participating agencies in preparing this second Annual status Report. The following sections are these agencies' verbatim responses to this request for information. 
Environmental Protection Agency

EPA's contribution to the 1980 Annual status Report to the Congress on the Uranium Mill Tailings Remedial Action Program.

At the beginning of 1980, the Environmental Protection Agency's remaining major responsibilities under PL 95-604 were:

a.

To set generally applicable standards for remedial actions at 25 designated inactive uranium processing sites.

b.

To set generally applicable standards for tailings at active uranium processing sites.

c.

To prepare a report for Congress on the hazards of urantum mine wastes.

$$
\because:=6 r+
$$

Standards for Inactive sites

Two kinds of standards are needed for the remedial action program. First, standards are needed for the cleanup of open lands and buildings contaminated.by residual radioactive materials (mainly tailings) that have been dispersed by wind or water, or that have been used in construction or for other purposes in the vicinity of the original processing sites. second, standards are needed for disposal of the tailings piles themselves. Because of the higher indoor radon decay product concentrations that sometimes result when tailings are used in construction, EPA considers cleanup of contaminated buildings and open lands the most urgent remedial actions. The Agency gave highest priority to developing cleanup standards, therefore, and proposed them for public comment on April 22, 1980 (45 F.R. 27270-75). EPA also made the cleanup standards immediately effective as interim standards (45 F.R. 27366-8) in order to satisfy the requirement in section 108 (a) (2) of PL 95-604 that standards must have been promulgated before cleanup could be undertaken. They will be replaced by final standards when the public review process is completed. 
As Fiscal Year 1980 closed, draft disposal standards were being reviewed by EPA management and the other member agencies of the Interagency Working Group (Departments of Energy, Interior, and Justice, and the Nuclear Regulatory Commission). Careful review is necessary because the Agency must be sure that disposal of such piles will be governed by standards that assure public health protection for the long-term. The standards, though behind the schedule mandated by Congress in PL 95-604, are being developed as speedily as is consistent with the complex technical, economic, health, and social issues involved. EPA is also committed to producing documentations of its proposals, so that people in the affected areas will be able to comprehend and comment on its analyses and reasoning.

As explained in a public notice on June 19, 1980 (45 F.R. 41459), EPA will issue a draft Environmental Impact statement covering both the cleanup and disposal standards when the latter are proposed. The Agency expects this to occur in November 1980, and plans to hold public hearings on the complete set of proposed standards early in 1981.

\section{Standards for Active Sites}

EPA is required by PL 95-604 to promulgate generally applicable standards for tailinge associated with artive uranium mills. Much of the documentation developed for the standards for inactive sites and the public's review of it will be helpful in addressing cleanup and disposal standards for active mills. However, standards for active sites must in addition address any environmental and public health hazards from tailings during the operating life of a mill, a requirement which does not arise for inactive'sites. The Agency is planning to propose standards for active sites about the same time it promulgates final standards for inactive sites, near the end of Fiscal Year 1981.

Uranium Mine Waste Report

Section 114 (c) of the Uranium Mill Tailings Radiation Control Act of 1978 instructs EPA to provide a report to Congress that identifies the location and potential health, safety, and environmental hazards of uranium mine wastes and recommend programs, if necessary, to eliminate these hazards. A draft report entitled "Potential Health and Environmental Hazards of Uranium Mines Wastes" was completed in September 1979. Copies of 
the draft were distributed at that time for technical review and comnent to knowledgeable indiviuals in Federal and state agencies and in the private sector.

The report includes a list of names and locations of 340 active and 3389 inactive uranium mines. The various methods of mining uranium ore are briefly described, and the sources of effluents and wastes (airborne, aqueous, and solid) from underground, surface, and in situ leach mines are identified. Potential health and environmental effects are assessed using estimates of the radionuclide and stable trace metal concentrations in the effluents and wastes. Finally, conclusions and recommendations are presented based on the environmental modeling and dose assessments, general observations of mines, and other information gathered from a review of relevant literature on the subject.

Since January 1980, EPA has been improving the accuracy of the mine listing and revising the entire document according to comments and suggestions received by the many reviewers. 's iagaddition; the health effects assessments were revised using more recently developed computer codes to estimate health risks.

The revised draft report will be completed in the last quarter of 1980 for final review. 


\section{Nuclear Regulatory Commission}

The following is submitted in response to DOE's request for input to be incorporated in the 1980 Annual status Report to Congress on the Uranium Mill Tailings Remedial Action Program covering the period January 1, 1980 through september 30,1980 :

o. The Commission met with the Department of Energy and agreed on detailed plans and procedures to be followed in implementing the NRC review and concurrence functions specified in Title I of the Uranium Mill Tailings Radiation Control Act (UMTRCA) of 1978. It was also agreed that the DOE as the lead agency would formally request NRC participation as a cooperating agency in the NEPA/EIS process. In this manner NRC will be involved in reviewing the development of remegial action programs from the beginning.

- The NRC coordinated with the Department of Energy in the identification and initiation of research programs to be conducted in providing the technical bases for the remedial action program.

- In compliance with section 103 of UMTRCA, the Commisaion reviewed and concurred in proposed Cooperative Agreements with the Commonwealth of Pennsylvania and the state of $U$ tah regarding remedial actions at the designated processing sites in Canonsburg and Salt Lake City.

- The Commission cooperated with EPA in reviewing and providing comments on the Interim Cleanup standards for Inactive Uranium Processing Sites which were promulgated and become effective on April 22, 1980. 
The Department of the Interior maintains continuing, close liason with the Department of Energy Project office in Albuquerque. Appropriate communication and coordination points in field offices of the Department are identified as needed, site by site, to provide technical information, review plans, etc. Interior jurișiction under the Act covers publio lando which might be affected by remedial actions at certain sites.

Interior's expertise useful for current UMTRAP (Uranium Mill Tailings Remedial Action Program) activities is procedural information as requested in making appropriate contact with Indian tribal governments and technical information on public lands management, and natural resources.

\section{Department of Jưsitice}

Summary of Activities for 1980 Annual Status Report on the Inactive Uranium Mill Tailings Site Remedial Action Program

The Land and Natural Resources Division has been designated by the Attorney General to perform staff work necessary for the discharge of his responsibilities under the Uranium Mill Tailings Radiation Control Act of 1979 (the Act), P.I. 95-604. Mnre specifically, the Attorney General is to conduct a study under section $115(b)$ of the Act to determine the identity and legal responsibility of any person who owned, operated, or controlled any site designated under the Act.,

The work required under section $115(\mathrm{~b})$ of the Act is in progress, and no final conclusions have been reached. As indicated in the 1979 annual report, a substantial effort will be required to provide necessary answers to the issues posed by section $115(\mathrm{~b})$. As a part of this effort and to facilitate any future site acquisitions under section 104 of the Act, the Division, as of $9 / 30 / 80$, had obligated funding to secure full title services for the twenty-five (25) inactive sites designated for cleanup under the 
Act. The Division has also consulted with the Department of Energy on a variety of legal issues which have arisen in the course of the implementation actions conducted by the Department.

Finally, as indicated in the 1979 annual report, this Division is defending the United states in the case Won-Door v. United States, No. 109-78L, before the court of claims. In this lawsuit, the plaintiff (Won-Door) contends, in part, that radiological contamination from the mill tailings remaining at the vitro site in salt Lake city has effected a "taking" of plaintiff's use or enjoyment of its adjoining property. As of $9 / 30 / 80$, all proceedings in the case were stayed, on the government's motion, to afford the parties an opportunity to explore the applicability of the Uranium Mill Tailings Radiation Control Act of 1978. However, the Court has established october 17,1980 as the date upon which the current stay will terminate absent a voluntary resolution of the suit by the parties. The filing of this case is clear evidence that radiological taking cases pose a threat of liability of the government, and, to the greatest extent possible, that threat should be considered in carrying out the Act. 
13. State and Indian Tribe Activities

Affected states and Indian tribes were invited to submit material for this report concerning their participation in the remedial action program during FY 1980. The complete texts of their responses are included in Appendix F. 
This portion of the report deals primarily with those actions to be taken by the DOE in the implementation of the Act during FY 1981; where possible, extended forecasts of activities for FY 1982 and beyond are also given.

1. Radiological Assessment

As discussed in Section of 2.1 of Chapter II, the Office of Environment is in the process of conducting aerial and ground-level radiological surveys and a radon-monitoring program to further characterize the radiological conditions at the 25 designated processing sites, the office is also identifying and verifying vicinity properties for remedial action. In addition, during FY 1981, the Office of Environment will be initiating an extensive processing-site and vicinity-property certification survey program once general standards are promulgated and site-specific remedial action commences. Listed below are the four different types of radiological assessments that are forecast by the Environmental safety and Engineering Division to be initiated in FY 1981.

\section{FY 1981 Aerial Survey Forecasts}

- Ambrosia Lake, NM

- Lakeview, OR

- Naturita, co

- Tuba City, Az

- Green River, UT

- Maybell, co

- Slick Rock (2 sites), CO 
FY 1981 Ground Survey Forecasts

- Canonsburg, PA (Continuation of FY 1980 Survey)

- Saj.t Lake City, UT

- Durango, CO

- Gunnison, co

- Rifle (2 sites), Co

- Riverton, WY

- Shiprock, NM

- Mexican Hat, UT

- Lowman, ID (Continuation of FY 1980 survey)

FY 1981 Radon Monitoring Forecasts

- Canonsburg, PA (Continuation of FY 1980 program)

- Durango, CO is hom

- Salt Lake City, UT

FY 1981 Certification Survey Forecasts (Vicinity Properties)

- Canonsburg. PA

- Salt Lake City, UT

- Durango, CO 


\subsection{Planning Documents}

Planning documents currently under development by the office of Environment include certification plans, background and radiological assessment reports, and related public information materials.

\subsubsection{Background Report}

Early in FY 1980, work was completed on a draft DOE Background Report for the Uranium Mill Tailings Remedial Action Program. The purpose of the document is to provide a consolidated historical summary of the 25 designated processing sites that includes current data on assessment studies of these sites. Applicable sections of the draft report were provided for review and comments to the appropriate designated representatives of the ten affected states, the Navajo Tribe, the current owners of each of the designated sites, the National Laboratories, and interested Departmental offices. Upon receipt of inputs from these interested parties, their comments are being incorporated, where appropriate, into the report prior. to publication. This document will not only be valuable to the DOE program management but will serve as an information document for future public meetings and hearings involving the Department's implementation of the remedial action program. It is anticipated that the background report will be published in FY 1981.

\subsubsection{Certification Plan}

A generic certification plan is currently being developed. The anticipated publication date is mid-FY 1981. During the conduct of remedial action by the Office of Nuclear Energy, the Office of Environment will be obtaining continuing radiological data by analyzing soil samples and by performing radiological surveys to ascertain the adequacy of the decontamination effort. It is expected that these activities will provide the necessary data to certify that the remedial-action site and associated vicinity properties are put into compliance with the Environmental Protection Agency's promulgated standards. 


\section{Establishment of Cooperative Agreements}

The cooperative agreement with the state of $U$ tah is expected to be executed in FY 1981. It is expected that cooperative agreements also will be initiated in FY 1981 between DOE and the affected states and tribes for the following sites: Durango (Colorado), Shiprock (Navajo Nation), Grand Junction (Colorado), Riverton (Wyoming), Rifle (Old and New) (Colorado), and Gunnison (Colorado) .

\section{Acquisition and Disposition of Lands and Materials}

The Act provides for the acquisition by the states of designated processing or disposal sites as deemed appropriate by the secretary, with NRC concurrence. It is expected that the Canonsburg processing site will be the only site acquired in 1981. Under the terms of the Act, the DOE must make a formal determination that it is appropriate to acquire the site. An appraisal of the property that meets Federal.feriteria and takes into account the contaminated condition of the site also must be obtained. Other processing sites will be acquired in later years.

\section{National Environmental Policy Act Documentation}

NEPA-related studies have been initiated at the first four high-prlority sites, as noted in the Proqram status Chapter. 'Tt. is planner that the NEPA process will be completed at these sites in early 1982. The Remedial-Action-Process Schedule (Figure 3) shows the estimated periods of time that will be required for the NEPA process at 23 designated sites. Schedules have not been prepared for the sites at Baggs, Wyoming, and Falls City, Texas, because their designation status is uncertain. 
For sites from which tailings will be removed to new disposal sites, the EISs must evaluate technical, environmental, and socioeconomic factors associated with the use of the disposal sites. No state has as yet formally recommended disposal sites; such recommendations are necessary if NEPA-related site-specific studies are to proceed in a timely manner. However, the scheduled completion dates of draft EISs for these sites are not at present affected. Contractors to conduct NEPA-related studies and prepare EISs for the remaining high-priority sites will be selected in FY 1981.

\section{Program Planning}

Development of a series of planning documents that will guide program activities and integrate various aspects of the remedial action process has been initiated. Planning documents that are scheduled for preparation in FY 1981 include the UMTRA Project plan, the UMTRA Project Management Plan, a Public-Participation Plan, the NEPA Implementation Plan, and the Generic Program Plan.

\subsection{UMTRA Project Plan}

This document is scheduled for completion in early FY 1981. The project Plan will describe the program's acquisition strategy and work-breakdown structure. Its primary purpose is to guide scheduling and . cost-control efforts. 


\subsection{UMTRA Project Management Plan}

The UMTRA Project Management Plan is intended to complement the overall Project Plan; its publication will follow that of the latter document. The. Project Management Plan will describe the program's management organization and define the interactions of the various contractors with each other and with DOE personnel.

\subsection{Public-Participation Plan}

The Public-Participation Plan will describe the means by which public comment will be encouraged for the development of remedial-action plans. This document is scheduled for publication in early FY 1981.

\subsection{NEPA Implementation Plan}

$$
1: \sin \sin 11
$$

The NEPA Implementation Plan and ancillary guideline documents, which are described in section 7 of Chapter II, were prepared in draft form in FY 1980 and have been submitted for review. The plan is expected to be published in final form in early FY 1981.

\subsection{Generic Program Plan}

The purpose of the Generic Program Plan is to outline in generic form a program to assess, evaluate, and reduce the potential radiological health hazard to the public from the accumulation of uranium-mill tailings resulting from the milling of uranium ore. The document, which was developed in draft during early FY 1980 by the office of Environment, is being reviewed by the office of Nuclear Energy and is to be a joint Departmental publication between these two major offices. The plan outlines program activities from the identification of candidate remedial-action sites and vicinity properties to the decontamination, decommissioning, and certification of such sites and properties. Further, the document addresses the Department's program-management responsibilities and outlines methods for the dissemination of information to the public. The joint publication of the generic plan is scheduled for FY 1981 . 


\section{Remedial Action}

A technology-development effort was initiated, and research in the reduction of indoor radon-daughter concentrations was undertaken at a vicinity property in Salt Lake City, as discussed in Section 9 of Chapter II. In addition, considerable effort was devoted in FY 1980 to developing remedial-action schedules for future years.

\subsection{Processing sites}

-. Preliminary schedules for remedial actions at the designated processing sites have been developed. Detailed schedules for remedial actions at the first four high-priority sites are shown in Figures $4 \mathrm{~A}$ through 4D. The estimated time required for the consumation of legally mandated prerequisites such as negotiation of a cooperative agreement, site acquisition, and completion of the NEPA process is such that remedial action at the highest-priority sites will not begin before late FY 1982. It is planned that work will start in 1982 at salt Lake City and Canonsburg and in 1983 at Durango and Shiprock. The proposed sequence of remedial action for 2.3 sites is shown in Figure 3 . As noted previously, the status of the sites at Baggs, Wyoming, and Falls City, Texas, is uncertain; consequently they have been omitted from the preliminary schedules.

\subsection{Vicinity Properties}

Remedial action at designated vicinity properties associated with the Salt Lake City and Canonsburg sites is scheduled to begin in FY 1981. Remedial action at the Salt Lake City firestation site is scheduled to begin in April 1981. 
REMEDIAL ACTION PROJECT MASTER SCHEDULE

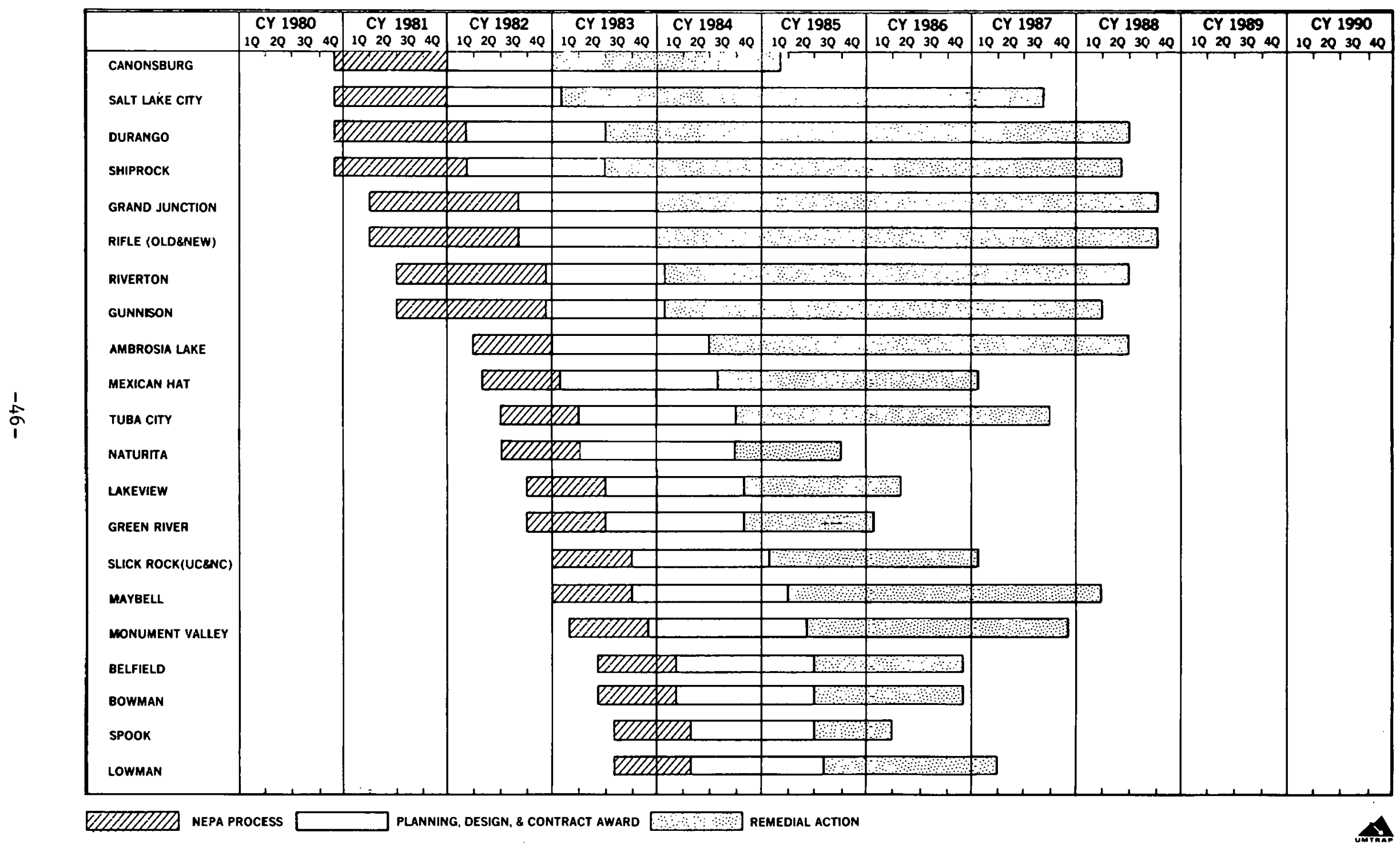

FIGURE 3 


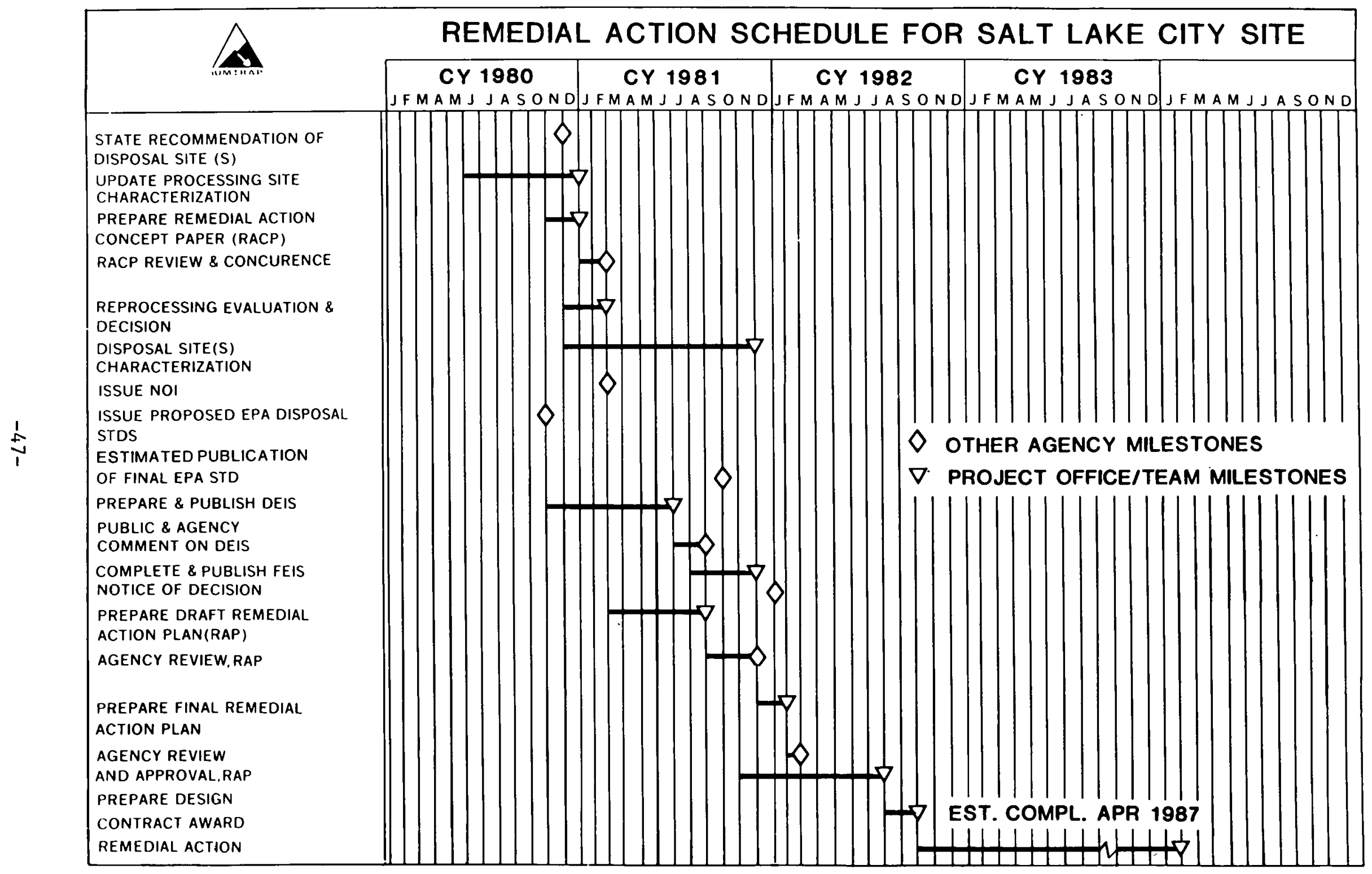

FGURE 4A 


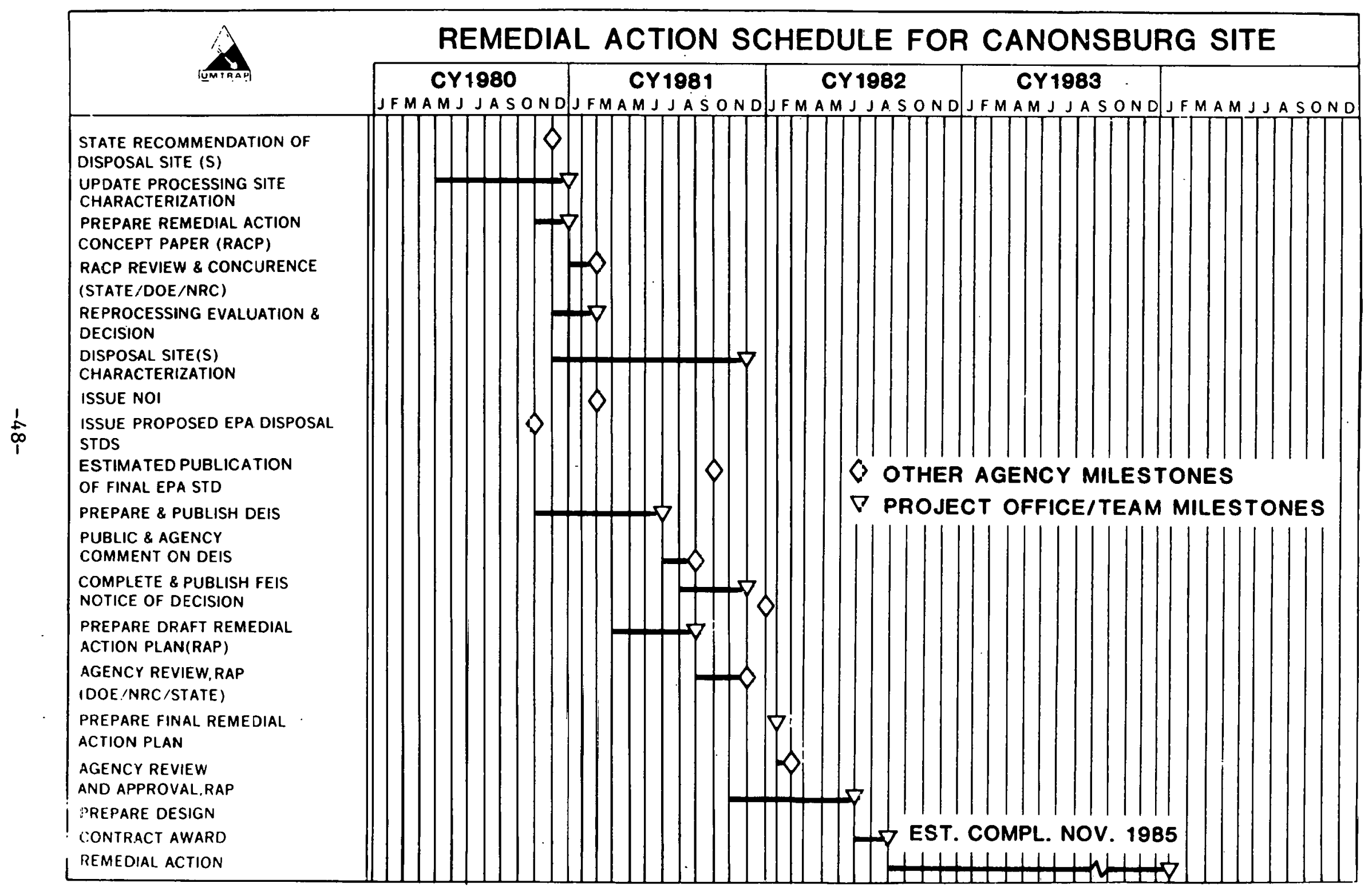

FGURE 4B 


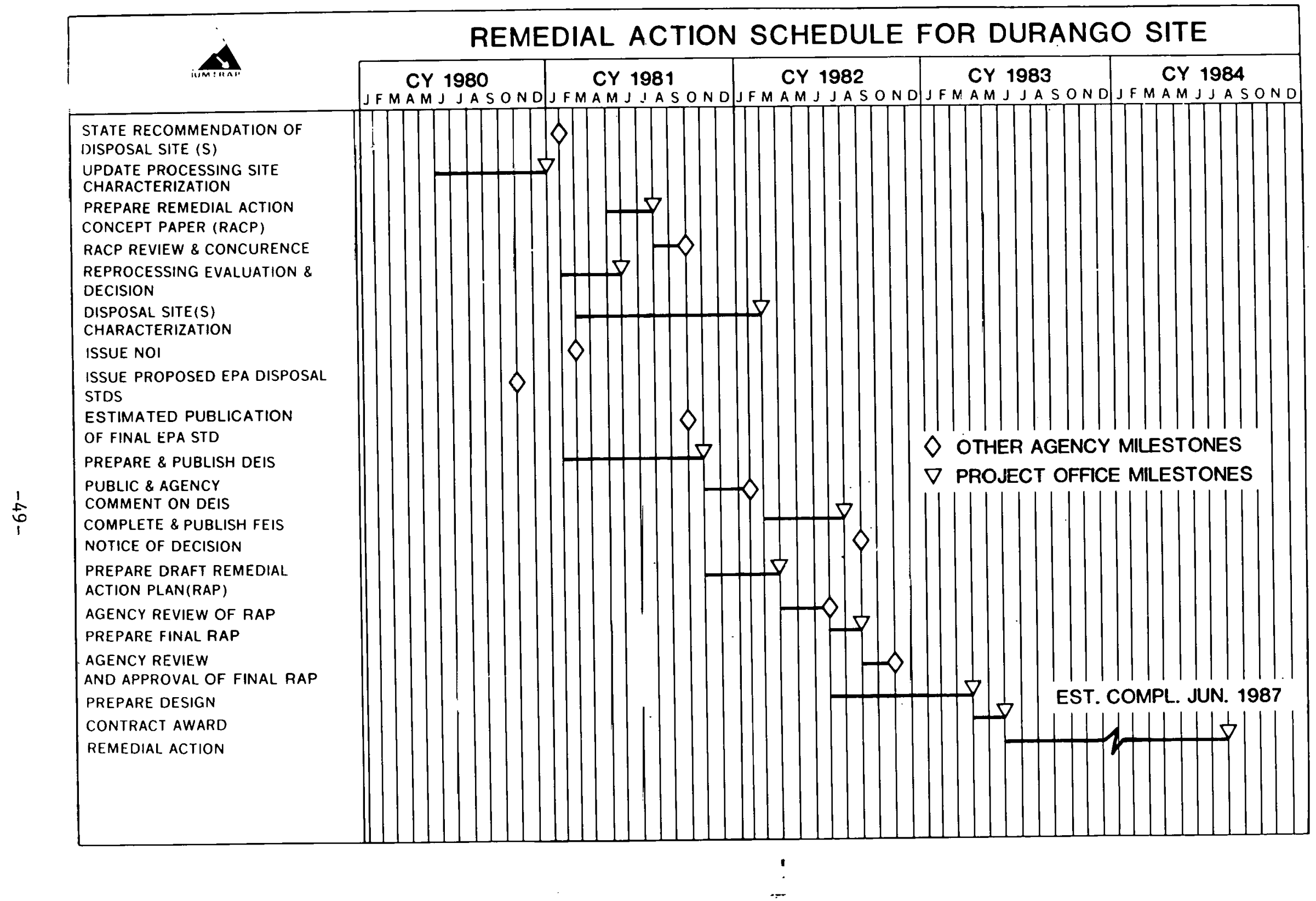

FIGURE 4C 


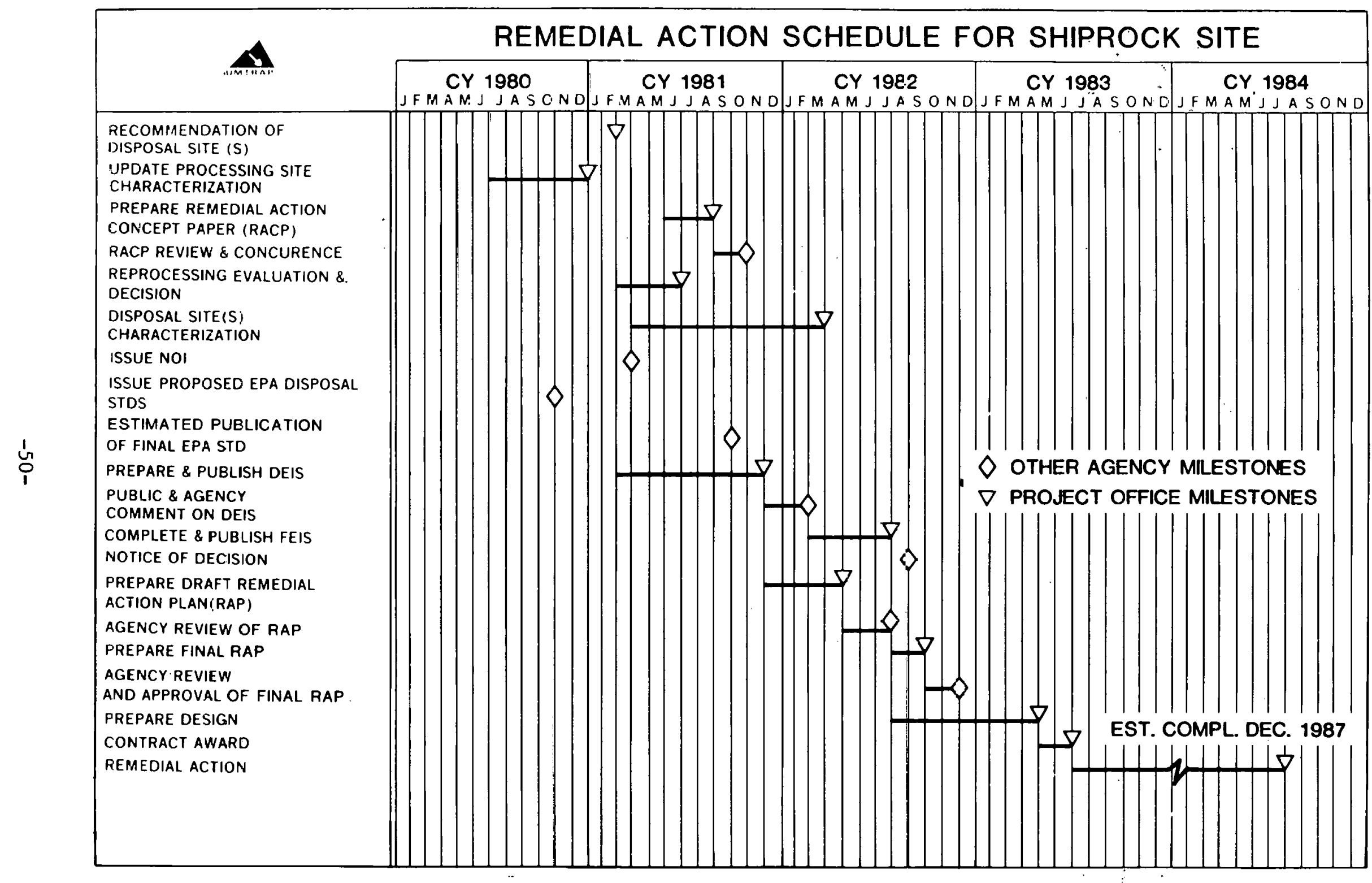

FEURE 40 ... 


\section{PROGRAM FUNDING}

Initial DOE funding for the execution of the mandates of Public Law 95-604 was included as an element of DOE's Decontamination and Decommissioning Program when managed by ASEV. As a result of the transfer of programmatic functions from ASEV to ASNE, the management responsibility for remedial action at designated processing sites was transferred to ASNE and included as an element of the Nuclear Waste Management Program. Total funding levels and actual costs for FY 1980 and projected costs for FY 1981 are as follows:

1. FY 1980 Costs

ASNE

Planning and Studies

Engineering

Environmental

Research and Development

Remedial Action

Site Acquisition

Management Support

Surveys

ASEV

Aerial surveys

Ground Surveys

Radon Monitoring Program

$$
\begin{array}{r}
\$ 1,144,000 \\
50,000 \\
621,000 \\
2,230,000 \\
- \\
- \\
1,194,000 \\
510,000 \star \\
\hline \$ 5,749,000
\end{array}
$$

h.
440,000

740,000

416,000 
ASEV

Site Certification Surveys".

Disposal site Evaluation

Environmental support : Service

195,000

Total

$\$ 1,791,000$

^\$510,000 transferred from ĀSNE to ASEV for surveying.

2. FY 1981 Projected costs

\section{ASNE}

Planning and studies

Engineering

Environmental

Research and Development

Remedial Action

Site Acquisition

Management Support

Total

$$
\begin{array}{r}
2,110,000 \\
766,000 \\
2,030,000 \\
4,094,000 \\
1,000,000 \\
2,500,000 \\
2,700,000 \\
\hline \$ 15,200,000
\end{array}
$$

\section{ASEV}

Aerial Surveys

Radiological (Ground) Survey

Radon Monitoring Program

Site Certification Surveys

Disposal Site Evaluation

Environmental support Service

Total

$$
\begin{array}{r}
\$ 315,000 \\
1,345,000 \\
530,000 \\
200,000 \\
- \\
200,000 \\
\$ 2,590,000
\end{array}
$$


LIST OF APPENDICES

APPENDIX A

APPENDIX B

APPENDIX C

APPENDIX D

APPENDIX E

APPENDIX F

APPENDIX G
PUBLIC LAW 95-604

MODEL STATE/DOE COOPERATIVE AGREEMENT

SUMMARY OF EPA INTERIM "AND PROPOSED STANDARDS

REPROCESSING ACTIVITIES INVOLVING INACTIVE

URANIUM MILL TAILINGS PILES, FEDERAL REGISTER NOTICE

PUBLIC PARTICIPATION PROGRAM - LISTS OF TASK FORCE MEMBERS.

INPUT FROM STATES AND INDIAN TRIBES

B IBLIOGRAPHY 
APPENDIX A

PUBLIC LAW 95-604 


\section{Public Law 95-604}

\section{5th Congress}

\section{An Act}

To otborre the Secrets of Bnerg to epter Into cooperative agreements with certaln stated respectlor residnal radlosctlve materlal at eristing altea. to proride for the resolatlon of aranlom mll tallinga ander the Atomle Enerco Act of 1854, and for other purposen.

Bo it onacted by the Senate and Bouse of Representatives of tho Onited States of America in Congress assembled,

\section{BHORT TITHE AND TABLF OP CONTHNTB}

Uranium Mill Trilings Radiation Control Act of 1978 .

Section 1. This Act may be cited as the "Uranium Mill Tailings Radiation Control Act of 1978".

Nor. B, 1978

[H.R. 13650] 42 USC 7901

\section{TABLE OF CONTENTS}

Sec 1, 8bort tule and tahie ne comtesta. Bec 2 Findings and purposes.

\section{TITLE I-RENGEIAL ACTION PBOGRAM}

8ec. 101. Delnltione.

8ec. 102 Deslgastlod of procesulag alter.

Bec. 108. State cooperative agreements.

Bec. 10L Acquisition and diaposition of land and mintertale.

Sec. 105 . Indian trlbe cooperative agreements.

Bec. 108 . Aequialtion of lands by Secretary.

Bec 107. Financlal a Bsiatapce.

Bec. 108 Remedial action.

Bec. 100. Rules.

Bec. 110. Eaforcement

Sec. 111. Pablle partlclpation.

8ec. 112. Termination: eothorization.

Sec. 113. Limitation.

8ec, 114. Reporta in Congrens.

Bec 115. Active opers tions: Llabluts for remedlal setion.

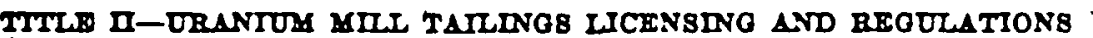

Bec. 201. Dennitton.

8ec. 202. Custody of disposal tite.

Bec 203 . 1 athortty to estsbilsb certalo requitremance

8ec 204 Cooperation with Btates.

Bec. 206. Aotbortities of Commlaston respecting certaln bjpmduct material.

Bec. 200 sothortty of EDvironmental Protectios. Agency respecting certalo bsproduct material

Bec 207. Apthortzation of approprlatloas for moth

Bec. 208. Etrective date.

Bec. 209. Consolidatton of Uleenses and procedurea.

TITLE II-8TUDY ANU DESIGNATION OF TWO. MUL TAILINGS BITES

Bec so1. Study.

IN NEW MEXICO

Bec. 302 Deslensuton hy Becretarg.

\section{FINDIYOB AND PURPOSES}

Szc. 2. (a) The Congress finds that uranium mill tailings located at 42 USC 7901. active and inactive mill operations ms pose a potential and signifcant radiation bealth hazard to the public, and that the protection of 
the public health, safety, and welfare and the regulation of interstate commerce require that every reasonable effort be made to provide for the stabilization, disposal, and control in a safe and environmentally sound manner of such tailings in order to prevent or minimize radon diffusion into the en rironment and to prevent or minimize other environmental hazerds from such tailings.

(b) The purposes of this Act are to provide-

(1) in cooperation with the interested States, Indian tribes, and the persons who ora or control inactive mill tailings sites, a program of assessment and remedial action at such sites, including, where appropriate, the reprocessing of tailings to extract residual uranium and other mineral values where practicable, in order to stabilize and control such tailings in a sa fe and environmentally sound manner and to minimize or eliminate radiation bealth hazards to the public, and

(2) a progtam to regulato mill tallings during uranium or thorium ore processing at active mill operations and after termination of such operations in order to stabilize and control such tailings in a safe and environmentally sound manner and to mini. mize or eliminate radiation health hazards to the public.

TITLE I-REMTEDIAL ACTION PROGRAS

\section{DEFTNTIONB}

42 USC 7911. SEC. 101. For purposes of this titlo-

(1) The term "Secretary" means the Secretary of Energy.

(2) The term "Conmission" means the Nuclear Regulatory Commission.

(3) The term "Administrator" means the Administrator of the Environmental Protection Agency.

(4) The term "Indian tribe" means any tribe, band, clan, group, pucblo, or community of Indians recognized as eligible for serrices provided by the Secretary of the Interior to Indians.

(5) The term "porson" means any individual, association, partnership, corporation, frm, joint venture, trust, government entits, and any other entity, except that such term does not include any Indian or Indian tribe.

(6) The term "processing site" meang-

(A) sny site, including the mill, containing residual radioactive materials at which all or substantialls all of the ura. nium was produced for sale to any Foderal agency prior to January 1,1971 under a contract with any Federal agency, except in the case of a site at or near Slick Rock, Colorado, unless-

(i) such site was owned or controlled as of January 1 , 1978 , or is thereafter owned or controlled, br any Federa] agencs, or

(ii) a license (issued by the Commission or lts pred.

42 USC 2011

Dote.

42 USC 2021. ocessor agency under the Atomic Energy Act of $195 t$ or hy a State as permitter under section 274 of such Act) for the production at such site of ans uranium or thorium product derired from ores is in effect on January 1, 1978, or is issued or renewed after such date; and

(B) any other real property or improvement thereon which- 
(i) is in the vicinity of such site, and

(ii) is determined by the Secretary, in consultation with the Commission, to be contaminated with residual radiosctive materials derived from such site.

Any ownership or control of an area by a Federal agency which is acquired pursuant to a cooperative agreement under this title shall not be treated as ownership or control by such agency for purposes of subparagraph (A) (i). A license for the production of any uranium product from residual radioactive materials shall not be treated as a license for production from ores within the meaning of subparagraph (A) (ii) if such production is in accordance with section 108 (b).

(7) The term "residual radioactive material" means-

(A) waste (which the Secretary determines to be radioactive) in the form of tailings resulting from the processing of ores for the extraction of uranium and other valuable constituents of the ores; and

(B) other waste (which the Secretary determines to be radioactive) at a processing site which relate to such processing, Including any residual stock of unprocessed ores or lowgrade materials.

(8) The term "4ailings" means the remaining portion of a metal-bearing ore after some or all of such metal, such as uranium, has been extractod.

(9) The term "Federal agency" includes any executive agency as defined in section 105 of title 5 of the United States Code.

(10) The term "United States" means the 48 contiguous States and Alaska, Hawaii, Puerto Rico, the District of Columbia, and the territories and possessions of the United States.

DERIONATION OF FROCEBSINO BTTES

Src. 102. (a) (1) As soon as practicable, but no later than one year after enactment of this Act, the Secretary shall designate processing sites at or near the following locations:

Salt Lake Cit, Otah

Green River, Utah

Dlexican Hat, Utah

Durango, Colorado

Grand Junction, Colorado

Rifle, Colorado (two sites)

Gunnison, Colorado

Neturita, Colorado

Maybell, Colorado

Slick Rock, Colorsdo (two sites)

Shiprock, New Mlesico

Ambrosia Lake, Nex Mrexico

Riverton, Wyoming

Converse County, Wyoming

Lakeview, Oregon

Falls City, Teras

Tuba City, Arizons

Monument Valley, Arizona

Lowwan, Idaho

Cannonsburg, Pennoylvania

$$
\begin{aligned}
& N \cdot D . \\
& \text { N. } P .
\end{aligned}
$$


Remodial action. Subject to the provisions of this title, the Secretary shall complete remedial action at the above listed sites before his authority terminstes under this title. Tho Secretary sluall within one year of the date of enactment of this Act also designate all other processing sitos within the United States which he determines roquires remedial ection to carry out the purposes of this title. In making such desigastion, the Secretary shall consult with tho Administrator, the Commission, and the affected States, and in the case of Indian lands, the eppropriate Indian tribe and the Secretary of the Interior.

(2) As part of his designation nndar this subsection, the Secretary, in consultation with the Commission, shall determine the boundaries of each such site.

(3) No site or structure with respect to which remedial action is

86 Stat 222. authorized under Public Law $92-314$ in Grand Junction, Colorado, may bo docignatod by the Secretery as a proressing kita under this section.

(b) Within one year from the date of the ensctment of this Act, the

Healtb barand asensment.

Notification. Socretary shall assess the potential health hazard to the public from the residual radiosctive materials at designated processing sites. Based upon such ascessment, the Secretary shall, within such one jear period. establish prioritics for carrying out remedial action at each such site. In establishing such priorities, the Secretery shall rely prima rily on the advice of the Administrator.

(c) Within thirty days after making designations of processing sites and establishing the priorities for such sites under this section, the Secretary shall notify the Governor of each affected State, and, where appropriate, the Indian tribes and the Secretary of the Interior.

(d) Tho designations made, and priorities established, by the Secretary under this section shall be final and not be subject to judicial review.

(o) (1) The designstion of processing sites within one year after enactment under this section shall include, to the marimum ertent practicable, the areas referred to in section $101(6)(B)$.

(2) Notwithstanding the one yesr limitation contained in this soction, the Secretary may, after such one year period, include any ares described in section 101 (6) (B) as part of a processing site designated under this section if he determines such inclusion to be appropriate to carry out the purposes of this title.

\section{ETATE COOPERATTV AOREENENTB}

42 USC 7913. Sxc. 103. (a) After notifying a State of the designation referred to in seztion 102 of this title, the Secretary subject to section 113 , is authorized to enter into cooperative ngreements with such State to perform remedial actions at each designated procrssing site in such State (other than aite located on Indian lands referred to in section 105). The Secrotary shall, to the greatest ertent practicable, enter into sach agreements and carry out such remedial actions in accordance with the priorities established by him under section 102. The Secretary ahall commence preparations for cooperative agreements with respect to each designated processing site as promptly as practicable following the designation of each site.

(b) Each cooperative agreement under this section shall contain

Termo and Conditions. ouch terms and conditions as the Secretary deems appropriate and consistent with the purposes of this Act, including, bat not limited 
to, a limitation on the nse of Federsl assistance to those costs which are directly requirad to complete the remedial action selected pursuant to section 108.

(c) (1) Except where the State is required to acquire the processing sito as provided in subsection (a) of section 104, each cooperative agreement with a State under section 103 shall provide that the State shall obtain, in a form prescribed by the Secretary, written consent from any person holding any record interest in the designated processing site for the Secretsry or any person designated by him to perform remodial action at such site.

(2) Such written consent shall include a waiver by each such person Wiver. on behalf of himself, his heirs, successors, and assigns-

(A) relessing the United States of any lisbility or claim thereof by such person, his heirs, successors, and assigns concerning such remedial action, and

(B) holding the United States harmless against anp claim by such person on behalf of himself, his heirs, successors, or assigns arising out of the performance of any such remedial action.

(d) Fach omperative agreement under this section shall require the State to assure that the Secretary, the Commission, and the Administrator and their authorisod reprecentativeo havo a permanent right of entry at any time to inspect the processing site and the site provided pursuant to section 104 (b) (1) in furtherance of the provisions of this title and to carry out such agreement and enforce this Act and any rules prescribed under this Act. Such right of entry under this section or section 106 into an area described in section $101(6)(B)$ shall terminate on completion of the remedial action, as determined by the Secretsry.

(e) Each agreement under this section shall take effect only apon the concurrence of the Commission with the terms and conditions thereof.

(f) The Secretary may, in any cooperative agreement entered into under this section or extion 105 , provide for reimbursoment of the uctual costs, as determined by the Secretary, of any remedial action - performed with respect to so much of a designated processing site as is described in section 101 (6) (B). Such reimbursement shall be made only to a property owner of record at the time such remedial action was undertsken and only with respect to costs incurred by such property owner. No such reimbursement may be made unless-

(1) such remedial action was completed prior to enactment of this Act and unless the application for such reimbursement was filed by such owner within one yesr after an agreement under this section or section 105 is approred by the Secretary and the Commission, and

(2) the Secrotary is satisfied that such action adequately achieves the purposes of this Act with respect to the site concerned and is consistent with the standards established by the Administrator pursuant to section 275(a) of the Atomic EnerES Act of 1954 .

Pacs p. 3039.

ACQUISTTION ANO DIBPOSITION OF LANDB AND YUTERIALB

Sec. 104. (a) Each cooperative agreement under section 103 shall require the State, where determined appropriate by the Secretary with the concurrence of the Commission, to acquire any designated process- 
ing site, including where appropriste any interest therein. In determining whether to require the State to acquire a designated processing site or interest therein, consideration shall be given to the prevention of windfall profits.

Residual rediostive

(b) (1) If the Secretary with the concurrence of the Commission meterial. remoral. determines that removal of residual radioactive material from a procossing site is appropriate, the cooperative agreement shall provide that the State shall aoquire land (including, whers appropriate, any interest therein) to be used as a site for the permanent disposition and stabilization of such residual radionctive materials in a safe and environmentally sound manner.

(2) Acquisition by the State shall not be required under this subsection if a site located on land controlled by the Secretary or made available by the Secretary of the Interior pursuant to section 106 (a) (2) is designated by the Secretary, with the concurrence of the Commission, for such disposition and stabilization.

(c) No State shall be roquired under subsection (a) or (b) to acquire any real property or improvement outside the boundaries of-

(1) that portion of the processing site which is described in soction 101 (6) (A), and

(2) the site used for disposition of the residual radioactive materials.

(d) In the case of each processing site designated under this title other than a site designated on Indian land, the State shall take such action as may be necessary, and pursuant to regulations of the Secre. tary under this subsection, to assure that any person who purchases such a processing site a fter the removal of radioactive materials from such site shall be notitied in an appropriate manner prior to such purchase, of the nature and extent of residual radioactive materials removed from the site, including notice of the date when such action

Notification. took place, and the condition of such site after such action. If the State is the owner of such site, the State shall so notify any prospective purchaser before entering into a contract, option, or other arrange-

Rules and regulations. ment to sell or otherwise dispose of such site. The Secretary shall issue appropriate rules and regulations to require notice in the local land records of the residual radioactive materials which were located at any processing site and notice of the nature and extent of residual radioactive materials removed from the site, including notice of the dato when such action took place.

(e) (1) The terms and conditions of anj cooperative agreement with a State under section 103 shall provide that in the case of any lands or interests thereib acquired by the State pursuant to subsection (a), the State, with the concurrenco of the Secretary, and the Commission, may-

(A) soll sucb lands and interests,

(B) permanently retain such land and interests in lands (or donate such lands and interests therein to another governmental entity within such State) for permanent use br such State or entity solely for park, recreational, or other public purposes, or

(C) transfer such lands and interests to the United States as provided in subsection ( $t)$.

No lands may be sold under subparagraph (A) without the consent of the Secretary and the Commission. No site may be sold under subparagraph (A) or retained under subparagraph (B) if such site is used for the disposition of residual radioective materials. 
(2) Before offering for sale any lands and interests thersin which comprise a processing site, the State shall offer to sell such lands and interests at their fair market ralue to the person from whom the State acquired them. to

(f) (1) Each agreement under section 103 shall provide that title and

(A) the residual radioactive materials subject to the agreement,

(B) any lands and interests therein which have been acquired by the Siate, under subsection (a) or (b), for the disposition of such materials,

shall be transferred by the State to the Secretary when the Secretary (with the concurrence of the Commission) determines that remedial action is completed in accordance with the requirements imposed pursuant to this title. No payment shall be made in connection with the transfer of such property from funds appropriated for purposes of this Act other than payments for any administrative and legal costs incurred in carrying out such transfer.

(2) Custody of any property transferred to the United Slutes under this subsection shall be assumed by the Secretary or such Federal agency as the President may designate. Notwithstanding any other provision of law, upon completion of the remedial action program authorized by this title, such property and minerals shall be maintained pursuant to a license issued by the Commission in such manner as will protect the public health, safety, and the environment. The Commission may, pursuant to such license or by rule or order, require the Secretary of other Federal agency having custudy of such property and minerals to undertake such monitoring, maintenance, and emergency measures necessary to protect public health and safety and other actions as the Commission deems necessary to comply with the standards of section 275 (a) of the Atomic Energy Act of 1954. The Secretary or such other Federal agency is authorized to carry out maintenance, monitoring and emergency measures under this suhsec. tion, hut shall talic no other action pursuant to such license, rule or order with respect to such property and minerals unless expressly authorized by Congress a fter the date of enactment of this Act. The United States shall not transfer title to propertr or interest therein acquired under this subsection to any person or State, except as provided in subsection $(h)$.

(g) Each agreement under section 103 which permits any sale described in subsaction (e) (1) (A) shall proride for the prompt reimbursement to the Secretary from the proceeds of such sale. Such reimbursement shall be in an amount equal to the lesser of -

(1) that portion of the fair mariret ralue of the lands or interests therein which bears the same ratio to such fair market value as the Federal share of the costs of acquisition by the State to such lands or interest therein bears to the total cost of such acquisition, or

2) the total smount poid by the Secrotary with respect to such acquisition.

The fair marbet value of such lands or interest shall be determined by the Secretary as of the date of the sale by the State. Any amounts received by the Secretsry under this title shall be deposited in the Treasury of the United States as miscellanoous receipts.

Past p. 3039.

Fair market relue. 
(h) No provision of any agrcement under eection 103 shall prohibit the Secretary of the Interior, with the concurrence of the Secre. tary of Energy and the Commission, from disposing of any subsurface mineral rights by sale or lease (in accordance with laws of the United States applicable to the sale, lease, or other disposal of such rights) which are associated with land on which residual radioactive materials sre disposed and which are transferred to the United States as required under this section if the Secretary of the Interior takes such action as the Commission deems necessary pursuant to a licanse issued by the Commission to asure that the residual radiosctive materials will not be disturbed by reason of any activity carried on following such disposition. If any such materials are disturbed by any such activit, the Secretary of the Interior shall insure, prior to the disposition of the minerals, that such materials will be restored to a as fo and environmentally sound condition as determined by the Commission, and that the costs of such resturation will be borne by the person acquiring such rights from the Secretary of the Interior or from his successur or assign.

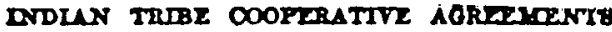

42 USC 7915.

Src. 105. (a) After notifying the Indian tribe of the designation pursuant to section 102 of this title, the Secretary, in consultation with the Secretary of the Incerior, is suthorizcd to enter into a cooperative agreaiment, sulject to section 113 , with any Indian tribe to perform ramedial action at a designated processing site lacated on land of such Indian tribe. The Secretary shall, to the greatest extent practicable, enter into such agreements and carry out such remedial actions in accordance with the priorities established by bim under section 102. In performing any remedial action under this section and in carrying out any continued monitoring or maintenance respecting residua] radioactive materials essociated with any site subject to a cooperative agreemont under this section, the Secretary sholl make full use of any qualified members of Indian tribes resident in the vicinity of any

Terms end such site. Each such agreement shall contain such terms and conditions conditione. as the Secretary deems appropriate and consistent with the purposes (1) The Indian tribe and any person bolding any interest in such land shall execute a waiver (A) relcasing the United States of ans liability ar claim thereof by such tribe or person concerning such renuedial action and (B) holding the United Stules harmlais ackinst any claim arising out of the performance of any such remedial action.

(2) The remedial action sball bo selected and performed in accordinnce with section 108 by the Secretary or such person as be may designate.

(3) The Secretary, the Commission, and the Administrator and thair authorized representatives shall have a permanent right of entry at any time to inspect such processing site in furtherance of the provisions of this title, to carry out such agreement, and to enforce any rules prescribed under this Act.

Each agreement under this section shall take effect only upon concurrence of the Commission with the terms and conditions thereof.

(b) When the Secretary with the concurrence of the Commission determines removal of residual radioactive materials from a process- 
ing site on lands described in subsection (a) to be appropriate, he shall provide, consistent with other applicable provisions of law, a site or sites for the permanent disposition and stabilization in a safe and environmentally sound manner of such residual radioactive materials. Such materials shall be transferred to the Secretary (without payment therefor by the Secretary) and permanently retained and maintained by the Secretary under the conditions established in a license issued by the Commission, subject to section $104(f)(2)$ and $(h)$.

\section{ACQUIEITION OF LATD BY EECRETART}

SEc. 106. There necessary or appropriate in order to consolidate in a safe and environmentally sound manner the location of residual radioactive materials which are removed from processing sites under cooperative agreements under this title, or where otherwise necessary for the permanent disposition and stabilization of such materials in such manner-

(1) the Secretary mas acquire land and intereste in land for such purposes by purchase, donation, or under any other authority of law or

(2) the Secretary of the Interior may make arailable public lands administered by him for such purposes in accordance with other applicable provisions of law.

Prior to acquisition of land under paragraph (1) or (2) of this subsection in any State, the Secretary shall consult with the Gorernor of such State. No lands mas be acquired under such paragraph (1) or (2) in any State in which there is no (1) processing site designated under this title or (2) active uranium mill operation, unless the Secretary has obtained the consent of the Gorernor of such State. No lands controlled by any Federal agency mas be transferred to the Secretary to carry out the purposes of this Act without the concurrence of the chicf administratire officer of such agencs.

\section{FINANCIAL ASGISTANCE}

SEc. 10i. (a) In the case of any designated processing site for which an agreement is executed, with any State for remedial action at such site, the Secretary shall pas 90 per centum of the actual cost of such remedial action, including the actunl costs of acquiring such site (and any interest therein) or any disposition site (and any interest therein) pursuant to section 103 of this title, and the State shall pay the remainder of such costs from non-Federal funds. The Secretary shall not pay the administratire costs incurred by any State to develop; prepare, and carry out ans cooperative agreement executed with such State under this title. except the proportionate share of the administrative costs associated with the acquisition of lands and interests therein acquired by the State pursuant to this title.

(b) In the case of any designated processing site located on Indian lands, the Secretary shall pay the entire cost of such remedial action.

\section{REXOEDLL ACTION}

SEc. 108. (8) (1) The Secretary or such person as he mag designate shall select and perform remedial actions at designated processing sites and disposal sites in accordance with the general standards prescribed
Truosfer to Secrevery of the Interios.

42 USC 7916.

Consulution.

42 USC 7917.

42 USC 7918. 
Pace, p. 3039.

Evaluation.

42 USC 2021.

42 USC 7919

Notice, bearing opportunity. by the Administrator pursuant to section 275 a. of the Atomic Energy Act of 1954. The State shall participate fully in the selection and performance of a remedial action for which it pays part of the cost. Such remedial action shall be selected and performed with the concurrence of the Commission and in consultation, as appropriate, with the Indian tribe and the Secretary of the Interior.

(2) The Secretary shall use technology in performing such remedial action as will insure compliance with the general standards promulgated by the Administrator under section $2 \% 5$ 8. of the Atomic Energy Act of 1934 and will assure the safe and environmentally sound stabilization of residual radioactive materials, consistent with eristing law. No such remedial action may be undertaken under this section before the promulgation by the Administrator of such standards.

(b) Prior to undertaking any remedial action at a desigated site pursuant to this title, the Secretary shall request expressions of interest from private parties regarding the remilling of the residual radioactive materials at the site and, upon receipt of any expression of interest, the Secretars shall evaluate among other things the mineral concentration of the residual radioactive materials at each designated processing site to determine whether, as a part of any remedial action program; recovery of such minerals is practicable. The Secretary, with the cuncurience of the Commission, may permit the recovery of such minerals, under such terms and conditions as he may prescribe to carry out the purposes of this title. No such recosery shall be permitted unless such recovery is consistent with remedial action. Any person permitted by the Secretary to recover such mineral shall pay to the Secretary a share of the net profits derived from such recovery, as determined by the Secretary. Such share shall not erceed the total amount paid by the Secretary for carrying out remedial action at such designated site. After payment of such share to the United States under this subsection, such person shall pay to the State in which the residual radioactive materials are located a share of the net profits derived from sucl. recovery, as determined by the Secretary. The person recovering such minerals shall bear all costs of such recovery. Any person carrying out mineral recovery activities under this paragraph shall be required to obtain any necessary license under the Atomic Energ: Act of 1954 or under State law as permitted under section $27 t$ of such Act.

RCI.S.

SEc. 109. The Secretary mä prescribe such rules consistent with the purposes of this Act as he deems appropriate pursuant to title $\nabla$ of the Department of Energ Organization Act.

\section{ENTORCEYTXT}

42 USC 7920. SEc. 110. (a) (1) Any person who violates any provision of this title or any cooperative agreement entered into pursuant to this title or any rule prescribed under this Act concerning any designated processing site, disposition site, or remedial action shatl be subject to an essessment by the Secretary of a civil penalt 8 of not more than $\$ 1,000$ per day per violation. Such assessment shall be made by order after notice and an opportunity for a public hearing, pursuant to section 554 of title 5. Cnited States Code.

(2) Any person against whom a penalty is assessed under this section may, within sizty calendar days after the date of the order of 
the Secretary assessing such penalty, institute an action in the United States court of appeals for the appropriate judicial circuit for judicial roview of such order in accordance with chapter 7 of title 5, United States Code. The court shall have jurisdiction to enter a judgment affirming, modifying, or setting aside in whole or in part, the order of the Secretary, or the court mas remand the proceeding to the Secretary for such further action as the court may direct.

(3) If any person fails to pay an assessment of a civil penalty after it has become a final and unappealable order, the Secretary shall institute an action to recorer the amount of such penalty in anj appropriate district court of the Linited States. In such action, the validity and appropriateness of such final assessment order or judgment shail not be subject to review. Section 402(d) of the Department of Energy Organization Act shall not apply with respect to the functions of the Secmitary under this section.

(4) No civil penalty may be assessed against the United States or any State or political subdivision of a State or any official or employee of the foregoing.

(5) Nothing in this section shall prevent the Secretary from enforcing any provision of this title or any cooperative agroement or any such rule by injunction or other equitable remedy.

(b) Subsection (a) shall not apply to any licensing requirement under the Atomic Encrey Act of 19.54. Such licensing requirements shall be enforced by the Commission as provided in such $A c t$.

\section{FOALIC PARTICLPATION}

Sec. 111. In carrying out the provisions of this title, including the designation of processing sites, establishing priorities for such sites, the selection of remedial actions, and the execution of cooperative agreements, the Secretary, the Administrator, and the Commission shall encourage public participation and, where appropriate, the Secrotary shall hold public hearings ivlative to such matters in the States where processing sites and.disposal sites a re located.

\section{TERATIATION; ATTHORIZATION}

Sra 112. (a) The authority of the Secretary to perform remedial action under this title shall terminate on the date seven years after the date of promulgation by the Administrator of general standards applicable to such remedial action unless such termination date is specifically extended by an Act of Congress enacted a fter the date of ensctment of this Act.

(b) The amounts authorized to be appropriated to carry out the purposes of this title by the Secretary, the Administrator, the Commission, and the Secretary of the Interior shall not esceed such amounts as are established in annual authorization Acts for fiscal year 1879 and each fiscal sear thereafter applicable to the Department of Energr. Any sums appropriated for the purposes of this title shall be arailable until expended.

\section{LTMTITIOX}

Src. 113. The authority under this title to enter into contracts or 42 USC 7923. otber obligations requiring the United States to make outlays may

5 USC $500 \mathrm{et} \mathrm{eag}$. Juriadiction.

42 USC 7172. nole.

42 USC 7921.

42 USC 7922. 
be exercised only to the extent provided in adrance in annual euthorization and appropriation Acts.

\section{BEPORTS TO CONGREBS}

42 USC 7924.

Sec. 114. (a) Beginning on January 1, 1980, and each year thereafter until January 1, 1986, the Secretary shall submit a report to the Congrass with respect to the status of the actions required to be taken by the Secretary, the Commission, the Secretary of the Interior, the Administrator, and the States and Indian tribes under this Act and any amendments to other laws made by this Act. Fach report shall-

(1) include dats on the actual and estimated costs of the program authorized by this title;

(2) describe the extent of participation by the States and Indian tribes in this program;

(3) eraluate the effectiveness of remedial actions, and describe any problems associated with the performance of such actions; and

(4) contain such other information as mas be appropriate. Such report shall be prepared in consultation with the Commission, the Secretary of the Interior, and the Administrator and shall contain their separate views, comments, and recommendations, if any. The Commission shall submit to the Secretary and Congress such portinn of the report under this subsection as relates to the authorities of the Commission under title II of this Act.

(b) Not later than July $1,19 i 9$, the Secretary shall provide a report to the Congress which identifies all sites located on public or acquired lands of the United States containing residual radjoactive materials and other raidoactive waste (other than waste resulting from the production of electric energy) and specifies which Federal apency has jurisdiction over such sites. The report shall include the identity of property and other structures in the vicinity of such site that are contaminated or may be contaminated by such materials and the actions planned or taken to remove such materials. The report shall describo in what munner such sites are adequately stabilized and otherwise controlled to prevent redon diffusion from such sites into the environment and other environmental barm. If any site is not so stabilized or controlled, the report shall describe the remedial actions planned for such site and the time trame for performing such antions. In preparing the reports under this section, the Secretary shall avoid duplication of prenous or ongoing studies and shall utilize all information available from other departments and agencies of the United

Cooperation. States respecting the subjoct matter of such report. Such agencies shall cooperate with the Secretary in the preparation of such report and furnish such information as available to them and Decessary for such report.

(c) Not later than January 1, 1980, the Administrator, in consultation with the Commission, shall provide a trpurt to the Congtess which identifes the location and potential bealth, safety, and enrironmental hazards of unanium mine wastes together with recommendations, if any, for a program to eliminate these hazards.

(d) Copies of the reports required by this section to be submitted to the Congress shali be separately submitted to the Committees on Interior and Insular Afisirs and on Interstate and Foreign Commerce 
of the House of Representatives and the Committee on Energs and Natural Resources of the Senate.

(e) The Commission, in cooperation with the Secretary, shall ensure that any relevant information, other than trade secrets and other proprietary information otherwise exempted from mandatory disclosure under any other provision of la $\mathrm{w}$, obtained from the conduct of eacb of the remedial actions authorized by this title and the subsequent perpetual care of those residual radioactire materials is documented systematically, and made publicly arailable conveniently for use.

ACTIVE OFERATIONB; WABTITT FOR REYCEDLL $\triangle$ CTION

SEc. 115. (a) No amount may be expended under this title with respect to any site licensed by the Commission under the Atomic Energy Act of 1954 or br a State as permitted under section 274 of such Act at which production of any uranium product from ores (other than from residual radionctive materials) takes place.

(b) In the case of each processing site designated under this title, the Attorney General shall conduct a study to determine the identity and legal responsibility which any person (other than the United States, a State, or Indian tribe) who owned or operated or controlled (as determined by the Attorney Geperal) such site before the date of the enactment of this Act may have under any law or rule of law for reclamation or other remedial action with respect to such site. The Attorner General shall publish the results of such study, and proride copies thereof to the Congress, as promptly as practicable following the date of the enactment of this Act. The Attorney General, based on such study, shall, to the extent he deems it appropriate and in the public interest, take such action under any provision of $18 \mathrm{w}$ in effect when uranium was produced at such site to require payment by such person of all or any part of the costs incurred by the United States for such remedial action for which be determines such person is liable.

\section{TITLE II-URANIUA ATLL TAILINGS LICENSING AND REGULATION DEFINITION}

Sec. 201. Section 11e of the Atomic Energy Act of 1954, is amended to read as follows :

"e. The term 'byproduct material' means (1) any radioactive material (except special nuclear material) yielded in or made radiosctive by exposure to the radiation incident to the process of producing or utilizing epecial nuclear material, and (2) the tailings or wastes produced by the extraction or concentration of uranium or tborium from any ore processed primarily for its source material content."

\section{CUBTODI OF DIBPOEAL ETTE}

Sxc. 202. (8) Chapter 8 of the Atomic Energy Act of 1954, is amended by adding the following new section at the end thereof:

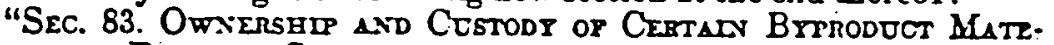
mela and Digrosal StTzes. -

"a. Any license issued or renewed after the effective date of this section under section 62 or section 81 for any activity which results in the production of any byproduct material, as defined in section 11e.

42 USC 7925.

42 USC 2011

note.

42 USC 2021.

Study.

42 USC 2014.

"Byproduct material."

42 USC 2111 et reg.

42 USC 2113.

42 USC 2002, 2111.

42 USC 2014. 
(2), shall contain such terms and conditions as the Commission determines to be necessary to assure that, prior to termination of such license-

"(1) the licensee will comply with decontamination, decomimissioning, and reclamation standards prescribed by the Commission for sites (A) at which ores were processed primarily for their source material content and (B) at which such byproduct material is deposited, and

(2) ownership of any byproduct material, as defined in sec-

42 USC 2014.

tion 11 e. (2), which resulted from such licensed activity shall be transferred to (A) the United States or (B) in the State in which such activity occurred if such State exercises the option under subsection $b$. (1) to acquire land used for the disposal of byproduct material.

Any license in effect on the date of the enactment of this section shall either contain such terms and conditions on renewal thereof after the effective dato of this section, or comply with paragraphs (1) and (2) upon the termination of such llcanse, whiohever first oceurs:

Rule, regulation

"(b) (1) (A) The Commission shall require by rule, regulation, or or onder. order that prior to the termination of any license which is issued atter the effective date of this section, title to the land, including any interests therein (other than land owned by the United States or by a State) which is used for the disposal of any byproduct material, as defined by section 11 e. (2), pursuant to such license shall be transferred to-

"(A) the United States, or

(B) the State in which such land is located, at the option of such State.

"(2) Unless the Commission determines prior to such termination that transfer of title to such land and such byproduct material is not necessary or desirable to protect the public liealth, safety, or welfare or to minimize or eliminate danger to life or property. Such determination shall be made in accordance with section 181 of this Act. Notwithstanding any other provision of law or ans such determination, such property and materials shall be maintained pursuant to a license issued by the Commission pursuant to section $84(\mathrm{~b})$ in such manner as will protect the public bealth, safety, and the environment.

"(B) If the Commission determines hy order that use of the curface or subsurface estates, or both, of the land transferred to the United States or to a State under subparagraph (A) would not endanger the public health, safety, welfare, or environment, the Commission, purguant to such regulations as it may prescribe. shall permit the use of the surface or subsurface estates, or both, of such land in a manner consistent with the provisions of this section. If the Commission permits such use of such land, it shall proride the person who trans. ferred such land with the right of first refusal with respect to such use of such land.

"(2) If transfer to the United States of title to such byproduct material and such land is required under this sertinn, the Secretary of Energy or any Federal agency designated by the President shall, following the Commission's determination of compliance under sub. section c, assume title and custody of such byproduct material and land transferred as provided in this subsection. Such Secretary or Federal agency shall maintain such material and land in such manner as will protect the public health and safoty and the en rironment. Such 
custody may be transferred to enother officer or instrumentality of the United States only upon approval of the President.

"(3) If transfer to a State of title to such byproduct material is required in accordance with this subsection, such State shall, following the Commission's determination of compliance under subsection $d$., assume title and custody of such byproduct material and land transferred as provided in this subsection. Such State shall maintain such material and land in such manner as will protect the public health, safety, and the environunent.

"( 4 ) In the case of any such license under section 62, which was in effect on the effective date of this section, the Commission may require, before the termination of such license, such transfer of land and interests therein (as described in paragraph (1) of this subsection) to the United States or a State in which sucb land is located, at the option of such State, as may be necessary to protect the public health, welfare, and the environment from any effects associated with such byproduct material. In exercising the authority of this paragraph, the Commission shall take into consideration the status of the omnership of such land and interests therein and the ability of the licensee to transfer title and custody thereof to the United States or a State.

"(5) The Commission may, pursuant to a license, or by rule or order, require the Secretary or other Federal agency or State baving custody of such property and materials to undertake such monitoring, maintenance, and emergency measures as are necessary to protect the public health and safety and such other actions as the Commission deems necrssary to comply with the standards promulgated pursuant to section 84 of this Act. The Secretary or such other Federal agency is authorized to carry out maintenance, monitoring, and emergencs measures, but shall tabe no other action pursuant to such license, rule or order, with respect to such property and materisls unless expressly authorized by Congress after the date of enactment of this Act.

"(6) The transfer of tit le to land or byproduct materials, as defined in section 11 c. (2), to a State or the United States pursuant to this cub. section shall not relieve any licensee of lisbility for any fraudulent or negligent acts done prior to such transfer.

(7) Siaterial and land transferred to the United States or a State in accordance with this subsection shall be transferred without cost to the United States or a State (other than administrative and legal costs incurred in carrying out such transfer). Subject to the provisions of paragraph (1) (B) of this subsection, the United States or a Stato shall not transfer title to material or property acquired under this subsection to any person, unless such transfer is in the same manner as provided under section $104(\mathrm{~b})$ of the Uranium Mill Tailings Radiation Control 1 et of 1978.

4 (8) Tho provisions of this subsection respecting transfer of titlo and custody to land shall not apply in the case of lands beld in trust by the United States for any Indian tribe or lands omned by such Indian tribe subject to a restriction against alienstion imposed by the United States. In the case of such lands which are used for the disposal of byproduct material, as defined in section 11 e. (2), the licenseo shall be required to enter into such arrangements with the Commission as mas be appropriate to assure the long-term maintenance and monitoring of such lands by the United States.

"c. Upon termination on any license to which this section spplies, the Commission ehall determine whether or not the licensee has com-

Pask p. 3039. 
Effective date. 42 USC 2113 nole:

42 USC 2014.

42 USC 2201.

4?. IISC 2231. plied with all applicable standards and requirements under such license.".

(b) This section shall be effective three jears after the enactment of this $A$ ct.

(c) The table of contents for chapter 8 of the Atomic Energy Act of 1954, is amended by inserting the following new item after the item rolating to section 82 :

"Bec 88. Ownerablp and cuntodj of certaln byproduct matertal and dloposel atein".

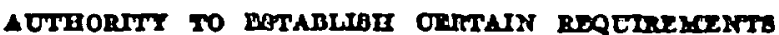

Sra 203. Section 161 of the Atomic Energy Act of 1954, is amended by adding the following new subsection at the end thereof:

"z. Establish by rule, regulation, or order, after public notice, and in accordance with the requirements of section 181 of this Act, such standards and instructions as the Commission may deem necessary or desiroble to ensuro-

"(1) that an adequate bond, surety, or other financial arrangement (as determined by the Commission) will be prorided, before termination of any license for byproduct material as defined in section 11 e. (2), by a licensee to permit the completion of all requirements established by the Commission for the decontamination, decommissioning, and reclamation of sites, structures, and equipment used in conjunction witb byproduct material as so defined, and

(2) that-

(A) in the case of any such license issued or renewed after the date of the enactment of this subsection, the need for long term maintenance and monitoring of such sites, structures and equipment after termination of such license will bo minimized and, to the maximum extent practicable, eliminated; and

"(B) in the case of each license for such material (whether in effect on the date of the enactment of this section or issued or renewed theres fter), if the Commission determines that any such long-term maintenance and monitoring is necessary, the licensee, before termination of any license for byproduct material as defined in section 11 e. (2), will make available such bonding; surety, or otber fuancial arrangements as may be necessary to assure such long-term maintenance and monitoring.

Such standards and Instructions promulgated by the Commission pursunnt to this subsection shall take into account, as determined by the Commission, so as to avoid unnecessary duplication and expense, performance bonds or other finaneial arrangements which are required by other Federal agencies or State agencies and/or other local governing bodies for such decommissioning, decontamination, and reclamation and long-term maintenance and monitoring except that nothing in this paragraph shall be construed to require that the Commission accept such bonds or arrangements if the Commission determines that such bonds or arrangements are not adequate to carry out subparagraphs (1) and (2) of this subsection.".

\section{COOPERATION WITH ETATES}

42 USC 2021. SEc, 204. (a) Section 274 b. of the Atomic Energy Act of 1954, is amended by adding ${ }^{a s}$ defined in section 11 e. (1) after the words 
"brproduct materials" in paragraph (1) by renumbering paragraphs (2) and (3) as paragraphs (3) and ( 4 ; and by inserting the following new paragraph immediately after paragraph (1):

"(2) byproduct materials as defined in section $11 \mathrm{e.}(2) ; "$.

(b) Section $274 \mathrm{~d}$. (2) of such Act is amended by inserting the following before the word "compatible": "in accordance with the requirements of subsection 0 . and in all other respects".

(c) Section $274 \mathrm{n}$. of such Act is amended by adding the following new sentence at the end thereof: "As used in this section, the term 'agreement' includes any amendment to any agreement.".

(d) Section $274^{\prime} j$. of such $A c t$ is amended-

(1) by inserting "all or part of" a fter "suspend";

(2) by inserting "(1)" after "finds that"; and

(3) br sdding at the end before the period the following: ", or (2) the State has not complied with one or more of the requirements of this section. The Commission shall periodically review such agreements and actions taken by the States under the agreements to ensure compliance with the provisions of this section.".

(e) (1) Section 2 it of such $A$ ct is amended by adding the following new subsection at the end thereof:

"o. In the licensing and regulation of byproduct material, as defined in section 11 e. (2) of this Act, or of any activity which results in the production of brproduct material as so defined under an agreement entered into pursuant to subsection b., a State shall require-

"(1) compliance with the requirements of subsection b. of section 83 (respecting onnership of byproduct material and land), and

"(2) compliance with standerds which shall be adopted by the State for the protection of the public health, safety, and the environment from hazards associated with such material which are equivalent, to the extent practicable, or more stringent than, standards adopted and enforced br the Commission for the same purpose, including requirements and standards promulgated by tho Commission and the Administratur of the Envifronmental Protection Agency pursuant to sections 83, 84, and 275, and

"(3) procedures which-

"(A) in the case of licenses, proride procedures under State law which include-

"(i) sn opportunity, a fter public notice, for written comments and a public hearing, with a transcript,

"(ii) an opportunity for cross examination, and

"(iii) a written determination which is based upon findings included in such determination and upon the evidence presented during the public comment period and which is subject to judicial reriew:

"(B) in the case of rulemakir.E, provide an opportunity for public participation through written comments or a public bearing and provide for judicial reriew. of the rule;

"(C) require for esch license which has a sipnificant impact on the human enrironment a written analrsis (which shall be arailable to the public beiore the commencement of any such proceedings) of the impact of such license, including any activities conducted pursuant thereto, on the environment, which analysis shall include- 
"(i) an essessment of the radiological and nonradiological impacts to the public bealth of the activities to be conducted pursuant to such license;

"(ii) an essessment of any impact on any waterway and ground water resulting from such activities;

"(iii) consideration of alternatives, including alternative sites and engineering methods, to the activities to bo conducted pursuant to such license; and

"(iv) considerstion of the long-term impacts, including decommissloning, deconlumination, and reclamation impacts, associated with actirities to be conducted pur. suant to such license, including the management of any byproduct material, as defined by section 11 e. (2); and

(D) prohibit any major construction activity with respect to such material prior to complying with the provisions of subparagraph (C).

If any State under such agreement imposes upon any licensee any requirement for the payment of funds to such State for the reclama. tion or long-term maintenance and monitoring of such material, and if transfer to the United States of such material is required in accord.

Anses p. 3033.

42 USC 2201.

42 USC 2021

42 USC 2014

42 USC 2021 Dote.

42 USC 2021

aote. ance with sertion $8.3 \mathrm{~b}$. of this $\mathrm{Act}$, such agreement shall be amended by the Commission to provide that such State shall transfer to the United Strtes upon termination of the license issued to such licensee the total amount collexted by such State from such license for such purpose. If such payments are required, they must be sufficient to ensure compliance with the standards established by the Commission pursuant to section $161 \mathrm{x}$. of this Act. No State shall be required under paragraph (3) to conduct proceedings concerning any license or regulation which would duplicate proceedings conducted by the Commission.".

(f) Section $274 \mathrm{c}$ of such Act is amended by inserting the following new sentence after paragraph (4) thereof: "The Commission shall slso retain authority under any such agreement to make a determina tion that all applicable standards and requirements have been met prior to termination of a license for byproduct material, as defined in section 11 e. $(2) . "$.

(g) Nothing in any amendment made by this section shall preclude ony State from exercising any other authority as permitted under the Atomic Energ; Act of 1954 respecting any byproduct material, as defined in section 11 e. (2) of the Atomic Energr Act of 1954.

(b) (1) On or before the date three years after the date of the enactment of this Act, notwithstanding any amendment made by this title, any State may exercise any authority under State law respecting byproduct matcrial, as defined in axtion $11 \mathrm{e}$. (2) of the Atomic Energy Act of 1954. in the same manner, and to the same extent, as permitted before the enactment of this Act.

(2) An agreement entered into with anr State as permitted under section 274 of the Atomic Energr Act of 1054 with respect to byproduct material as defined in section 11 e. (2) of such Act. may be entered into at anr time after the date of the enactment of this lct but no such agreement may take effect before the date three years after the date of the enactment of this Act. 


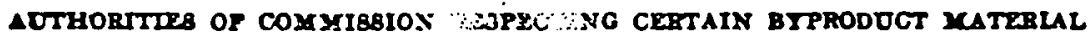

Sec. 205. (a) Chapter $\varepsilon$ is the Atomic EnergS Act of 1934, is 42 USC 2111 es amended by adding the following new section at the end thereof:

"Sec. 84. A othortirs of Commission Respectino Certali Brirod DOCT MATERLL-

"B. The Commission shall insure that the management of any byproduct material, as defined in section $11 \mathrm{e} .(2)$, is carried out in such manner ag-

"(1) the Commission deems appropriate to protect the public health and safety and the environment from radiological and nonradiological hazards associated with the processing and with the possession and transfer of such material,

"(2) conforms with applicable general standards promulgated by the Administrator of the Environmental Protection Agency under section 275 , and

"(3) conforms to general requirements established by the Commission, with the concurrence of the Administrator, which are, to the maxiruum extent practicable, at least comparable to requirements applicable to the possession, transfer, and disposal of similar hazardous material regulated by the Administrator under the Solid Waste Disposal Act, as amended.

"b. In carrying out its authority under this section, the Commission is authorized to-

"(1) by rule, regulation, or order require persons, officers, or instrumentalities exempted from licensing under section 81 of this Act to conduct monitoring, perform remedial work, and to comply with such other measures as it may deem necessary or desirable to protect bealth or to minimize danger to life or property, and in connection with the disposal or storage of such bj product msterial; ind

(2) make such studies and inspections and to conduct such monitoring as may be necessery.

Any violation by any person other than the United States or any officer or employee of the United States or a State of any rule, regulation, or order or licensing provision, of the Commission established under this section or section 83 shall be subject to a civil penalty in the same manner and in the same amount as violations subject to 8 civil penalty under section 234. Nothing in this section affects any sutbority of the Commission under any other provision of this Act.".

(b) The first sentence of section 81 of the Atomic Energy Act of 1954, is amended to read as follows: "No person may transfer or receive in interstate commerce, manufacture, produce, transfer, acquire, own, possess, import, or export any byproduct material, except to the extent authorized by this section, section 82 or section 81.". 42 USC 2112.

(c). The table of contents for such chapter 8 is amended by insert- Supra ing the following new item after the item relating to section 83:

"Sec. 84. Authoritles of Comminaton ropectlos certaln bjprodoct materinl".

AOTBORTT OF ENVIRON YENTAL PROTECTION AGENCT RESPECTHO CERTAN BTPRODOCT YATERIAL

Sec. 206. (a) Chapter 19 of the Atomic Energy Act of 1954, is smended by inserting after section 274 the following new section:

"Sec. 275. Hialti and ENTtronme.Ttal Standardo por Urantox seg.

42 USC 2114.

12 USC 2014.

Infre.

42 USC 6901

Dote.

Rule, regulation

or order.

42 USC 2111.

Civil peasity.

Ances p. 3033.

42 USC 2282

42 USC 2111.

Mar Tananos.-

42 USC 2021. 42 USC 2022. 
Rule.

"a As soon as practicable, but not later than one year after the dato of enactment of this section, the Administrator of the Environmental Protection Agency (hereinafter referred to in this section as tho 'Administrator') shall, by rule, promulgate standards of genera] application (including standards applicable to licenses under section IOf (b) of the Uranium Mill Tailings Radiation Control Act of 1878) for the protection of the public beslth, safety, and the environment from radiological and nonradiological hazards associated with residual radioactive materials (as defined in section 101 of the Uranium Mill Tailings Radiation Control Act of 1978). Jocated at inactive uranium mill tailings sites and depository sites for such materials selected by the Secretary of Energy, pursuant to title 1 of the Ura. nium Mill Tailings Radiation Control Act of 1978. Standards promulgated pursuant to this subsection shall, to the marimum extent practirshle, be consistent with the requirements of tho Solid Waste

42 USC 6901

Dote.

Rule.

42 USC 2014.

12 USC 2021.

Publication in Ferderal Register. Notice, beariog opportanity.

Conoulution.

Judicial review. Disposal Act, as amended. The Administrator may periodically revise any standard promulgated pursuant to this subsection.

“b. (1) As soon as practicable, but not later than eighteen months ster the ensctment of this section, the Administrator shall, by rule, promulgate standards of general application for the protection of the public health, safety, and the environment from radiological and nonradiological hazards associated with the processing and with the posoession, transfer, and disposal of byproduct material, as defined in section 11 e. (2) of this Act, at sites at which ores are processed primarily for their source macerial conteut or which aro used for the disposal of such byproduct material.

(2) Such generally applicable standards promulgated pursuant to this subsection for nonradiological hazards shall provide for the protoction of human health and the environment consistent with the otandards required under subtitle C of the Solid Waste Disposal Act, as amended, which are applicable to such hazards: Provided, hovoever, That no permit issued by the Administrator is required under this Act or the Solid W aste Ilisposal. Act, as amended, for the processing, possession, transfer, or disposal of byproduct material, as defined in bection 11 e. (2) of this Act. The Administrator may periodically revise any standard promulgated pursuant to this subsection. Within three years after such revision of any such standard, the Commission and any State permitted to exercise autbority under section 274 b. (2) shall apply ouch revised standard in the case of any license for byproduct materis] is defined in section $11 \mathrm{e} \mathrm{(2)} \mathrm{or} \mathrm{ang} \mathrm{revision}$ thereot.

"c. (1) Before the promilgation of ang rule pursuant to this section, the Administrator shall publish the proposed rule in the Federal Register, together with a statement of the research, analysis, and other available information in support of such proposed rule, and provide a perind of public comment of at least thirty days for written com. ments thereon and an opportunity, after such comment period and after public notic; for any interested person to present oral data, views, and arguments at a public hearing. There shall be a transcript of any such hearing. The Administrator shall consult with the Commission snd the Secretary of Energy before promulgation of any such rule.

"(2) Judicial revier of anp rule promulgated under this section may bo obtained by any interested person only upon such person filing 
a petition for review within sirty days after such promulgation in the United States court of appeals for the Federal judicial circuit in which such person resides or has his principal place of business. A copy of the petition shall be forth with transmitted by the clerk of court to the Administrator. The Administrator thereupon shall fle in the court the written submissions to, and transcript of, the written or oral proceed. ings on which such rile was based as provided in section 2112 of title 28, United States Code. The court shall hare jurisdiction to review the rulo in accordance with chapter 7 of title 5 , United States Code, and to grant appropriate relief as provided in such chapter. The judpment of the court affirming, modifying, or setting aside, in whole or in part, anr such rule shall be final, subject to judicial reviex by the Supreme Court of the United States upon certiorari or certification as provided in section 1254 of title 28, United States Code.

"(3) Añ rule promulgated under this section shall not take effect earlier than sixty calendar days after such promulgation.

"d. Implementation and enforcement of the standards promulgated pursuant to subsection $b$. of this section shall be the responsibility of the Conwinissiun in the conduct of its licensing activities under this Act. States exercising authorits pursuant to section $274 \mathrm{~b}$. (2) of this Act shall implement and enforce such standards in accordance with subsecton 0 . of such section.

"e. Nothing in this Act applicable to byproduct material, as defined in section $11 \mathrm{e}$. (2) of this Act, shall a ffect the authority of the Adminis. trator under the Clean Air Act of 1970, as amended, or the Federal Water Pollution Control Act. as amended.".

(b) The table of contents for chapter 19 of the Atomic Energy Act is amended by inserting the following new item after the item relating to section it:

"Bec. 275. Health and enfronmental atandards for uraniam mill tallings.".

\section{ACTHORIZATION OF APPROPRLATION FOR CRANTS}

Sec. 207. There is hereby authorized to be appropriated for fiscal Jear 1980 to the Nuclear Refulat or Commission not to exceed $\$ 500,000$ to be used for making grants to States which have entered into agreements with the Commission under section $27 t$ of the Atomic Energy Act of 1954 , to aid in the development of State regulatory programs ander such section which implement the provisions of this Act.

\section{EFTECTIV DATE}

SEc. 208. Except as otherwise provided in this title the amendments made by this title shall take effect on the date of the enactment of this Act.

CONBOLIDATION OP LICENBES ANT PROCEDURES

Src. 209. The Nuclesr Regulatory Commission sball consolidete, to the maximum extent practicable, licenses and licensing procedures under amendments made by this title with licenses and licensing procedures under other authorities contsined in the Atomic Energy Act of 1954 .
5 USC 701 et seq.

42 USC 2021.

42 USC 2014. 42 USC 7401 note. 33 USC 1251 note. 42 USC 2018 et seg.

42 USC 2014 note.

42 USC 2113 note.

42 USC 2011 sote. 


\section{TITIE III-STUDY ANT DESIGNATION OF TWO MILL. TAILINGS SITES IN NEW ALEICO}

\begin{abstract}
GIODT
42 USC 7941. Src. 301. The Commission, in consultation with the Attomey General and the Attorney General of the State of New Mlexico, shall con. duct a study to determine the estent and adequacy of the authority of the Commission and the State of New Mlexico to require, under the Atomic Energy Act of 1954 (as amended by title II of this Act) or under State suthority as permitted under section 274 of such Act or under other provision of law, the owners of the following active uranium mill sites to undertake appropriate action to regulate and control all residual radioactive materials at such sites to protect public bealth, safory, and the envirnnment: the former Homastake-Now Bexico Partners site near Milan, New Mexico, and the Anaconda carbonate process tailings site near Bluewater, New Mexico. Such study sball be completed and a report thereof submitted to the Con.

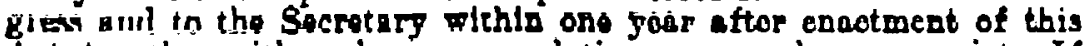
Act, together with such recommendations a may be appropriate. If the Commission determines that such authority is not adequato to regulate and control such materials at such sites in the manner provided in the frst sentence of this section, the Commiesion shall include in the report a statement of the basis for such determination. Nothing in this Act shall be construed to prevent or delay action by a State as permitted under section 274 of the Atomic Energs Act of 1854 or under any other provision of law or by the Commission to regulate such residual radioactive materials at such sites prior to completion of such study.

\section{DESIGNATION BT GECRETARY}

42 USC 7942. Sxc. 302. (a) Within ninety days from the date of his receipt of the report and recommendations submitted by the Commission under section 301, notwithstanding the limitations contained in section $101(6)$ (A) and in soction 115 (a), if the Commission determines, based on such study, that such sites cannot be regulated and controlled by the State or the Commission in the manner described in section 301 , the Secretary may designate either or both of the sites referred to in section 301 as a processing site for purposes of title I. Following such designation, the Secretary may enter into couperative agreements with Ner Mexico to perform remedial action pursuant to such title concerning only the residual radiosctire materials at such site result. ing trom uranium produced for sale to a Federal agency prior to January 1, 1071, under contrect with such agency. Any such desigas. tion shall be submitted by the Secretary, together rith his estiunato of the cost of carrying out such remedisl action at the desigasted site, to the Committee on Interior and Insular Affairs and the Committee on Interstate and Foreign Commerce of the House of Ropresentatives and to the Committee on Energy and Natural Resources of the Senate.

(b) (1) No designation under subsection (a) shall take effect before the expiration of one hundred and twenty calendar days (not includ. ing any day in which either House of Congress is not in session 
becsuse of an adjournment of ninre than three calendar days to a day certain or an adjournment sine die) after receipt by such Committees of such designation.

(c) Except as otherwise specifically provided in subeection (a), any remedial action under title $I$ with respect to any sites designated under this title ahall be subject to the provisions of title I (including the suthorization of appropriations referred to in section $112(\mathrm{~b}))$.

Approved November 8, 1978.

LEGISLATIVE HISTORY:

HOUSE REPORT No. 95-1480. PL I (Comm. on Interior and Insular Afrairs) and PL II (Comm. on Interstute and Foreigo Commerce).

CONGRESSIONAL RECORD. Vol. 12\$ (1978):

Oct 3, considered and passed House.

Oer 13, considered and pasued Senate. amended.

Oct 14. House coscurred in Sebate emendmeat with ameadmepts.

Oet 15. Senate concurred in House ameadment. 


\section{APPENDIX B}

MODEL STATE/DOE COOPERATIVE AGREEMENT 


\section{Cooperative Agreement}

This AGREEMENT, entered into this 1980, between the UNITED STATES OF AMERICA (hereinafter called the "Government") acting through the DEPARTMENT OF ENERGY (hereinafter called the "DOE"), and the STATE OF its (hereinafter called the "state"), acting through

\section{WITNESSETH THAT:}

WHEFEAS, the Uranium Mill Tailings Radiation Control Act of 1978 (hereinafter called the "Act") approved November 8, 1978, authorizes the Secretary to enter intc this Agreement with the state to perform remedial action at the inactive mill tailings site and vicinity property designated as "proceseing eites" by the secretary, and

WHEREAS, the purpose of this Agreement is to establish a program of assessmert and remedial action at the, processing site in order to stabilize and control such tailings in a safe and environmentally sound manner and to minimize or eliminate radiation heolth hazards to the public, and WHEREAS, the parties hereto are mutual?y desirous of entering into such an Agreement for the performance of such remedial action pursuant to the requirements of the A.ct under the terms set. forth below.

NOW THEKLFOKE, the parties hereto mutually aọrec as follows:

I. DEFINITIONS

As used throughout this Agreemert, the following terms shall have the meanings set. forth below:

A. The term "Secretary" means the secretary of Energy or any duly authorized refresentative.

B. The term "Commission" means the Nuclear Regulatory Commission or any dily authorized representative.

c. The term "Administrator" means the Administrator of the Environmental Protection Agercy or any duly authorized representative.

D. The term "State" means the state of duly authorized representative.

or any

E. The term "person" means any individual, association, partnership, corporation, firm, joint verture, trust, government entity, and any other entity, except that such term does not include any Indian or Indian Tribe. 
F. The term "processing site" means (1) any site including the mill, containing residual radioactive materials at which all or substantially all of the uranium was produced for sale to any Federal agency, unless such site was owned or controlled as of January 1, 1978, or is thereafter owned or controlled, by any Federal agency, or a license (issued by the Commission or its predecessor agency under the Atomic Erergy Act of 1954 or by a state as permitted under section 274 of such Act) for the product derived from ores is in effect on January 1, 1978, or is issued or renewed after such date: (2) any vicinity site, and (3) any residual radioactive material located at properties defined in (1) and (2).

G. The term. "vicinity site" refers to any real property or improvement thereon which is (1) in the vicinity of that portion of the frocessing site defined in Section $101(6)$ (A) of the ACL, and (2) is determined by the Secretary in consultation with the Comission, to be contaminated with residual radioactive materials derived from such site.

H. The term "head of the agency" as used herein means the Secretary, or his duly authorized representative, and the term "his duly authorized representative" means any person or persons or board (other than the DOE Contracting Officer) authorized to act for the head of the agency or the Secretary.

I. The term "DOE Contracting officer" means the person executing this Agreemert on behalf of the Governmer.t, and any other officer or cj.vilian employee who is properly designated in writing to the state 2.5 a DOE Contracting C.ficer; and the term includes, except as otherwise provided in this Agreement, the authorized representative of a DOE Contracting officer acting within the limits of his authority, when so designated in writing to the state.

J. Except as otherwise provided in this Agreement, the term "subcontracts" includes purchase orders under this Agreerient. 
K. The term "subcontractor" means the contractor to the state and all tiers of subcontracting thereunder.

I. The term "state Contracting officer" means the Director of the Bureau of Radiation and Occupational Health or any duly authorized representative of such official.

M. The term "Advance by Treasury check" means a payment made to the state by Treasury check, in accordance with the provisions of Treasury Circular No. 1075, upon request by the state before cash outlays are made for allowable costs incurred and anticipated to be incurred by the state.

N. The term "reimbursement by Treasury check" means a payment made to the State with a Treasury check upon request by the state or reimbursement for cash outlays made for allowable costs.

0. The term "program income" means the state's share of proceeds from: (1) any sale by the state of a processing site pursuant to Article $V$ of this Agreement; and (2) any remiliing of residual radioactive material done pursuant to Article II of this Agreement and section $108(b)$ of the Act. Program income does not. include any interest earned on advances of Government funds pursuant to this Agreement.

P. The term "residual radioactive materials" means: (1) waste at the processing site, which the secretary: determines to be radioactive, in the form of tailings resulting from the processing of ores for the extraction of uranium and other valuable constituents of the ores; and (2) other waste, which the secretary determines to be radioactive, at the processing site which relate to such processing, including any residual stock of unprocessed ores or low-grade materials.

Q. The term "EPA Standards" means those standards, promulgated as standards by rule of the Administrator pursuant to Section 275 of the Atomic Energy Act of 1954 as amended, of general application for the protection of the public health, safety, and the environment from radiological and nonradiological hazards associated with residual radioactive materials located at processing sites and depository sites.

R. The term "depository site" means any site, which may include the processing site, used for the permanent disposition, stabilization and control of residual radioactive materials in accordance with and pursuant to Title I of the Act and this Agreement. 
S. The term "remedial action" means the assessment and technical effort, including where appropriate the remilling of tailings to extract uranium and other mineral values where practicable, in order to stabilize and control the residual radioactive materials in a safe and ervironmentally sound manner and to minimize or eliminate radiation health hazards to the public.

II. DESCRIPTION OF REIIEDIAL ACTION PROGRAM

A. The program covered by this Agreement is a cooperative effort betreen the DOE and the State for the purpose of assessment and remedial action at the inactive mill tailings site and vicinity property designated by the Secretary as a "processing site" in order to stabilize and control such tailings in a safe and environmertally sound manner and to minimize or eliminate radiation health hazards to the public.

B. With the participation of the state and the concurrence of the Commission, the secretary shall select and perform the remedial action at the designated processing site and the disposal site, if separate, in accordance with the general standards prescribed by the Administrator pursuant to Section 275 of the Atomic Energy Act of 1954, as amended.

C. The Secretary shall use technology in performing the remedial action as will insure compliance with the general standards promulgated by the Administrator as provided for in paragraph B, above, and will assure the safe and ervironmentally sound stabilization of residual radioactive materials consistent with existing law.

D. No remedial action will be undertaken before the promulgation by the Administrator of the EPA standards provided for in paragraph $B$ above. However, the term "remedial action" does not include acquisition of a site. Nevertheless, the financial provisions in Articles III and IV of this Agreement do apply with regard to the actual costs of acquiring a processing site (and any interest therein) or any dispository site (and any interest the:rein). 
E. The detailed description of the work to be performed will be contained in a written Remedial Action Plan which will be developed by the LOE and the state. The Remecial Action Plan will be attached as appendicies to this agreemert, after hiving been approved by DOE and the State. The Plan shall become effective upon the written concurrerce of the commission, and it shall become a part of this Agreement upon such concurrence. This Plan may be modified jin writing in a nonsubstantive manner by mutual agreement of the parties without the formal concurrence of the Commission. All substantive modifications to the Remedial Action Plan by the farties must also have the written concurrence of the commission. However, no formal execution of an amendment to this Agreement is required for a modification to the Pemedial Action Plan.

F. Before the remedial action outlined in the Remedial Action Flan can be finally decided upon and implemented by the parties, the DOE must comply with the requirements of the National Environmental Policy Act of 1969.

G. Any remedial action taken pursuant to this Agreement shall be in accordance with the applicable provisions of the Act, including the provisions of Section 108 (b) regarding the remilling of residual radioactive materials.

\section{PAYMENTS}

A. The Secretary shall pay 90 percent of the allowable costs under this Agreement and the State shall pay the remaining 10 percert of such costs from non-Federal funds. Such costs shall be: (i) verifiable from the State's records; (ii) not included as contributions for any other Government assistance program; (iii) made for charges that are allowable costs; (iv) not paid by the Government under any other Government assistance program; and ( $v$ ) othervise conforming to the provisions of this Agreement and the Act.

B. Unless otherwise agreed by the parties and except as provided pursuant to Article XV, Procurement and Subcontracting̣, DOE will procure all necessary materials and services needed to perform the remedial action and acquisition of property. Accordingly, DCE will make payrent tc all contractors performing remedial action work and acquisition of property. 
The DOE shall submit quarterly, or at more frequent intervals by mutual agreerent between the state Contracting officer $\because$ and the DCF Contracting officer, standard Form 1034; "Public Voucher for purchases and Services Other Than Perscnal," a copy of which is attached as Appendix $E$, supported by a statement of allowable costs incurred by DOE. The DCE shall submit the form, original, and two copies, to the state Contracting officer. Prompt payment shall be made by the State for 10 percent of allowable costs.

C. The State shall submit quarterly, or at more frequent intervals by mutual agreenent between the state contracting Officer. and the DCE Contracting officer, an OMB Standard Form 270, a "Request for Advance or Reimbursement," a copy of which is attached as Appendix C to request payment for the LOE share of any project costs incurred by. the state. The state shall submit the OMB Standard rorm 270, original and two copies to the vOE contracting Officer. The DOE shall promptly make advance by Treasury Check or reimbursement by Treasury check, or a combination thereof, as payment to the state for ninety percent (908) of allowable costs. In lieu of paymert by advance or reimbirsement by Treasury check, the state may submit the OMB Standard Form 270 showing allowable cost incurred by the state and reouesting trat the DOE Contracting officer offset such costs against the State's share (10\%) of the total allowable costs.

D. At any time or times prior to final payment under this Agreemert, the DCE contracting officer may have the state invoices or vouchers and statements of cost audited.

The state shall maintain, and the DOE contracting officer shall heve the right tc examine books, records, documents and other evidence and accounting procecures and practices, sufficjent to reflect properly all direct and indirect costs of whatever nature claimed to have been incurred and anticipated to be incurred for the performance of this Agreement. Such right of examination shall include inspection at all reasonable times at the state's offices, or such parts thereof, as may be engaged in the performance of this Agreement as tc cost or pricing data submitted by the State. All documents, records and other materials described in this paragraph shall be made available at all reasonable times, for inspection, audit or reproduction, and shall be retained in accordance with the terms and conditions 
of Article XI of this Agreement. Each payment theretofore made shall be subject to reduction for amounts included in the related invoice or voucher which are found by the DOE Contracting officer, after consultation with the state, on the basis of such audit, not to constitute allowable cost as defined in Article IV "Allowable Cost." Any payment may be reduced for overpayments, or increased for underpayments on preceding invoices or vouchers. DOE will make available to the State copies of proposals, vouchers, supporting documentation and any technical and financial reports submitted by prime contractors selected to perform work under this Agreement.

E. Interest earned by the state on advances of Government funds pursuant to this Agreement shall be remitted to the DOE Contracting Officer.

\section{ALLOWABLE COSTS}

A. Payment for the allowable costs as hereinafter defined shall constitute full and complete compensation for the performance of work under this igreement.

B. Allowable costs under this Agreement shall be:

(1) Those direct costs (as determined by the $\mathrm{DOE}$ Contracting officer in accordance with Federal Management Circular (FMC) 74-4) incurred by the DOE and the State to:

a. Appraise and acquire property (and any interest therein) pursuant to Article $V$ of the Agreement when required by the secretary with the concurrence of the commission.

b. Design and perform the remedial action pursuant to and in accordance with the terms and conditions of this Agreement.

c. Pay relocation costs, pursuant to Article V of this Agreement, of all persons and materials relocated as a necessary part of the remedial action undertaken pursuant to this Agreement, or to alleviate potential health risk to occupants of designated sites as determined necessary by the secretary with the concurrence of the state.

(2) Those indirect costs (as required by this Agreement and as determined by the DOE Contracting officer in accordance with Federal Management Circular 
(FMC) 74-4l associated with the acquisition of property by the state or the transfer or property to the Government by the state pursuant to Article $V$ hereof, but shall not otherwise include any other indirect costs incurred by the DOE or the State to develop, prepare and carry out this Agreement.

\section{ACQUISITION, DISPOSITION, AND USE OF PROPERTY}

A. The State, when determined appropriate by the secretary with the concurrence of the commission, shall acquire the designated processing site, including where appropriate any interest therein. In the event that the Secretary's designation is amended to include any vicinity site and the state consents to acquisition of any such site (as more specifically provided in Article $V$, paragraph $D$, of this agreement), the state shall acquire such vicinity site including any interest therein.

B. If the secretary, with the concurrence of the Commission, determines that removal of residual radioactive material from the processing site is appropriate, the state shall acquire land (including, where appropriate, any interest therein) to be used as a site for the permanent disposition and stabilization of such residual radioactive materials in a safe and environmentally sound manner.

c. Acquisition by the state shall not be required under this article if a site located on land controlled by the secretary or made available by the secretary of Interior pursuant to section 106 of the Act is designated by the secretary, with the concurrence of the commission, for such disposition and stabilization.

D. The state, shall not be required under paragraphs $A$ and $B$, above, to acquire any real property or improvement outside the boundaries of (1) that portion of the processing site which is described in section 101(6) (A) of the Act, and (2) the site used for disposition of the residual radioactive materials, provided that the state may consent by amendment to this agreement to acquire any vicinity site subsequently included in the processing site designation by the secretary. Upon such consent the state shall acquire the vicinity site including where appropriate any interest therein. 
E. Except where the state is required to acquire the processing site pursuant to paragraph A of this Article, the state shall use its best efforts to obtain, in a form prescribed by the secretary, written consent from any person holding any record interest in the designated processing site for the secretary, or any person designated by the secretary to perform remedial action at the site. Such written consent shall: (1) include a waiver by each such person on behalf of himself, his heirs, successors and assigns (i) releasing the Government and the state of any liability or claim thereof by such person, his heirs, successors and assigns concerning such remedial action, and (ii) holding the Government and the state harmless against any claim by such person on behalf of himself, his heirs, successors, or assigns arising out of the performance of any such remedial action; (2) specify the remedial action to be performed; (3) provide that the remedial action shall be performed only by the DOE or such person as the DOE contracting Officer designated; and (4) provide that the state shall notify the owner of record, upon completion of the remedial action, of the nature and extent of the remedial action taken, pursuant to paragraph $J$ of this Article. The state shall advise the DOE Contracting officer, as soon as possible, whenever it is unable to obtain such written consent, whereupon the DOE Contracting officer shall instruct or advise the state in writing: (1) that the state should acquire the subject processing site consistent with the other provisions of this Agreement, (2) that no remedial action will be performed at the subject processing site; or (3) of such other determination made by the DOE in connection with the subject processing site.

F. The State shall assure that the secretary, the Commission, and the Administrator and their duly authorized representatives shall have a permanent right of entry at any time to inspect the processing site and the site provided pursuant to paragraph $B$ above, in furtherance of the provisions of Title I of the Act and to carry out this Agreement and enforce the provisions of the Act and any rules prescribed thereunder. This right of entry into an area described in section 101 (6) (B) of the Act shall terminate on completion of the remedial action, as determined by the secretary. 
G. In the case of any lands or interests therein acquired by the state pursuant to paragraph $A$, above, the state with the concurrence of the secretary and the: Commission, may (1) sell such lands and interests, (2) permanertly retain such land and interests in lands (or donate such lands and interests therein to another governmental entity within such state) for permanent use by state or entity solely for park, recreational, or other public purposes, or (3) transfer such Jands and interests to the United States as provided in paragraph $\mathrm{H}$, below. No site may be sold or retained under this paragraph $G$ if such site is used for the cisposition of residual radioactive materials. Before offering for sale any lands and interests therein which comprise the processing site, the: State shall offer to sell such lands and interests at thej.r fair market value to the person from whom the state acquired them.

H. If the secretary (with the concurrence of the commission) determines that remedial action is completed in accordance with the EFA standards, the state shall transfer to the Government title to: (1) the residual radioactive materials subject to this Agreement, and (2) any lands and interests therein that have been acquired by the State, under paragraphs (A) and (B) abcve, and used as a dispository site. No payment shall be made in connection with the transfer of such property from funds appropriated for purposes of the Act other than paymerts for any administrative and legal cost incurred in carrying out such transfer. The DOE shall thereafter bear all costs for maintenance, monitoring, and control of the residual radioactive materials and the site.

I. The State shall promptly reimburse the secretary from the proceeds of any sale made by the state pursuant to paragraph G(1), above. Such reimbursement shall be in an amount equal to the lesser of (1) that portion of the fair market value of the lands or interests therein which bears the same ratio to such fair market value as the Federal shere of the costs of acguisition by the State to such lands or interest therein bear to the total cost of such acquisition, or (2) the total amount paid by the secretary with respect to such acquisition. The fair market value of such lands or interest shall be determined by the Secretary as of the date of the sale by the state.

J. The state shali take such action as may be necessary, pursuant to regulations of the secretary, to assure that any person who purchases a processing site not owned by the state after the removal of radioactive 
materials from such site shall be notified prior to purchase of the nature and extent of residual radioactive materials removed from the site, including notice of the date when such action took place, and the condition of such site after such action. If the state is the owner of such site, the State shall so notify any prospective purchaser before entering into a contract, option, or other arrangement to sell or otherwise dispose of such site.

K. The State shall acquire real property pursuant to applicable state law, and pursuant to the requirements of the Department of Justice for acquisition of real property by Government agencies as provided in paragraph $M$ below.

I. The Secretary shall instruct the state to acquire that portion of the processing site described in section $101(6)(A)$ of the Act pursuant to this Article by written notice which informs the state of: (1) the acquisition required; (2) the legal description or location of the property to be acquired; (3) the estate or interest in the property to be acquired; and (4) the date by which such property is to be acquired.

M. The State, when directed by the DOE Contracting officer in writing, shall obtain an appraisal of that portion of the processing site described in section 101(6)(A) of the Act, regardless of whether or not the DOE has determined that the state should acquire such portion of the processing site pursuant to this Article. Any appraisal required pursuant to this paragraph or paragraph o of this Article shall be obtained as soon as possible and shall:

1. Be prepared in compliance with the "Uniform Appraisal Standards for Federal Land Acquisitions" (hereinafter referred to as the "Appraisal Standards") issued by the Interagency Land Acquisition Conference (1973).

2. Be done, to the extent possible, by experts qualified to determine amounts, quality, extractability, accessibility, and commercial demand of the residual radioactive materials (uranium), and, if possible, qualified to determine and certify to the extent to which the presence of the residual radioactive 
materials actually diminishes or enhances the market value of the millsite. At the option of the DOE Contracting officer and after discussion with the State Contracting officer, this portion of the appraisal (regarding residual radioactive materials) may be performed or obtained by the DOE rather than by the state. In that event, such portion shall be considered a supplement to the aopraisal and, therefore, the costs of preparing or cbtaining such portion shall be an allowable ccst under Article IV of this Agreement.

3. Be forwarded to the DOE Contracting officer.

N. Whenever the state is required tc acquire a processing site, depository site, or agrees to acquire a vicinity site, or any interest therein, pursuant to this Article:

1. The State shall make every reasonable effort to acquire expeditiously the site by necotiation:

2. The State shall obtain all necessary title evidence for use in negotiations for purchase and, if necessary, for use in condemnation proceedings in accordance with the "Standards for the Preparation of Title Evidence in Land Acouisitions by the United States."

3. The State shall obtain an appraisal, before the initiation of negotiations if not already done pursuant to paragraph $M$ of this Article. The appraisal shall be prepared in compliance with the Appraisal Standards and shall otherwise conform to the requirements of paragraph $\mathrm{N}$ of this Article. The owner or his designated representative ehall be given an opporturity to accompany the appraiser during his inspection of the site.

4. The State shall promptly furnish to the DOE Contracting officer a copy of the title evidence and the appraisal refort.

5. The secretary, before the initiation of negotiations by the State, shall establish an amount which the secretary believes to be a just maximum compensation for the processing site and shall notify the State of such emount (hereinafter referred to as the "Maximum Arount"). 
6. The State shall then proceed, pursuant to state law, to negotiate a purchase price and agreement to purchase the site. The state shall not negotiate a price in excess of the Maximum Amount.

7. The state, if unsuccessful in negotiating a purchase price at or below the Maximum Amount, shall then consult with the DOE Contracting officer for further direction. The DOE shall then either justify paying the amount asked for continued negotiations or authorize the institution of formal condernation proceedings by the state pursuant to State law.

8. No owner of a site shall be required to surrender possession before the state pays, to the extent allowed under State law, tre aọreed purchase price or deposits with the afpropriate state court, for the benefit of the owner, such amounts as are required to authc.rize the st.ate to take possession pending outcome nf a condemnation proceeding.

9. In no event shall the state either advance the time for condemation or defer negotiations or condemnation and the deposit of funds in state ccurt for the use of owner, to take any other action coercive in nature, in order'to compel an aogreement on the price to be paid for the site.

10. Upon a determination by DOE that any buildings, structures or improvements located upon the site must be decontaminated pursuant to the remedial action project or will be adversely effected by the remedial action profect, the state shall acquire an interest in all such buildings, structures or improvemerts and in the underlying land equal to the interest acquired in the site.

11. The state, as soon as practicable and to the extent allowed under state law, shall reimburse the ormer of site for: (i) recording fees, transfer taxes, and similar expenses incidental to conveying title to the site and improvements thereon; (ii) penalty costs for prepayment of any pre-existing recorded mortgage entered into in good faith encumbering the site; and (iii) the pro rata portion of real property taxes paid which are allocable to a period subsequent to the date that title is vested in the State, or the effective date of lawful possession by the state, whichever is the earlier. 
12. The State, upon acquisition of a site pursuant to this Article, shall forward to the DOE Contracting Officer: (i) copies of any accepted sales, donation, or exchange agreement; (ii) copies of title evidence; (iii) a map or plat of the land acquired; and (iv) copies of the deed to the state.

0 . Whenever the state is required to transfer title to a depository site pursuant to this Article, the State, at the time of such transfer, shall forward to the DOE Contracting officer a deed which conforms to applicable State law and with the Standards for the preparation of Title Evidence in Land Acquisitions by the United States, and which:

1. Is a general warranty deed. This requirement may be waived by the DOE Contracting officer, upon a proper showing, as to conveyances by the state acting solely in a representative capacity.

2. Shows the name of the state as grantor in the body of the deed and in its acknowledgement.

3. Conveys the land to the "United States of America, its successors, and its assigns."

4. Contains a proper description of the land.

5. Conveys by general warranty deed all the right, title and interest. of the state as grantor in and to any alleys, streets, ways, strips, or gores abutting or adjoining the land.

6. Contains no reservations or exceptions not approved by the DOE Contracting officer; however, when land is to be conveyed subject to certain rights, such as easements or mineral rights thought to be outstanding in third parties, they must not be excepted from the conveyance, but the deed shall be framed to convey by quitclaim all the state's right, title, and interest subject to the outstanding rights.

7. Refers to the deed(s) to the State, or other source of the State's title, by book, page, and place of record, wherever customary or required by statute. 
8. Contains a reference to the DOE as the Government agency for which the lands are being acquired. This statement should follow the description of the land and in no instance should it be included in the granting, habendum or warranty provisions of the deed.

9. Is signed, sealed, attested, and acknowledged by the State as grantor as required by applicable state law.

10. If executed by an attorney in fact, is signed in the name of the principal by the attorney, properly acknowledged by the attorney as the free act and deed of the principal, and be accompanied by the original or a certified copy of the power of attorney and satisfactory proof that the principal was living and the power in force at the time of its exercise.

11. Has affixed sufficient documentary revenue stamps, if required by state law.

P. The State, when determined appropriate by the DOE with the concurrence of the state and so instructed by the DOE Contracting officer, shall pay relocation expenses to all persons relocated as a necessary part of the remedial action project. Such payment of relocation expenses shall be pursuant to applicable state law. Provided that should there be no applicable state law, any payment of relncation expenses by the state shall be consistent with the provisions of the Uniform Relocation Assistance and Real. Property Acquisition Policies Act of 1970, Public Law 91-646, Sections 201 through 204, inclusive, and the Federal Property Management Regulations, Section 101-18.3.

VI. PUBLIC PARTICIPATION

A. The state will cooperate with the Government in implementing a public participation plan which will be made a part of the Remedial Action Plan provided for in Article II. E, above.

B. The parties shall coordinate all public information in connection with the remedial action program.

VII. RULES AND REGULATIONS

Article VII of the Agreement is amended by revision as follows: 
Except as otherwise provided in this Agreement, all activities under this Agreement shall be carried out pursuant to applicable Federal and State regulations, including but not limited to such rules and regulations promulgated or to be promulgated by the secretary pursuant to section 109 of tre Act.

VIII. COVENANT AGAINST CONTINGENT FEES

The State warrants that no person or selling agency has been employed or retained to solicit or secure this Agreement upon an agreement or understanding for a commission, percentage, brokerage, or contingent fee, excepting bolla fide erpluyees or bona fidc establiched commercial or selling agencies maintained by the state for the purpose of securing business. For breach or violation of this warranty, the Government shall have the right to annul this Agreement without liability or in its discretion to deduct from the Ayrement price or consideration, or otherwise recover, the full amount of such commission, percertage, brokerage, or contingent fee.

IX. OFFICIALS NCT TO BENEFIT

No member of or delegate to Congress, or Resident Commissioner, shall be aamitted to any share or part of this Aareement, or to any benefit that may arise therefrom; but this provision shall not be construed to extend to this Agreement if made with a corporation for its general benefit.

X. EQUAL OPPORTUNITY

Recipierts of DCE financial assistance awards which are provided under DOE Federal Assistance programs shall comply with Part 1040, Chapter $X$, Title 10 of the Code of Federal Regulations "Nondiscrimination in Federally Assisted Programs" (proposed rule) (10 CFR Part 1040) as puhlished in the FR Vol. 43, No. 222, Thursday, November 16, 1978 (pages 53658 through 53676) and when published as a final rule, 10 CFR Part 1040, provided. that no person shell on the ground of race, color, national origin, sex, handicap, or age be excluded from participation in, be denied the benefits of, be subjected to discrimination under, or be denied employment where the main purpose of the program or activity is to 
provide employment or when the delivery of program services is affected by the recipient's employment practices in connection with any program or activity receiving Federal assistance from DOE.

\section{During the performance of this Agreement, the state agrees} as follows:

A. The State will not discriminate against any employee or applicant for employment because of race, color, religion, sex, or national origin. The state will take affirmative action to ensure that applicants are employed, and that employees are treated during employment without regard to their race, color, religion, sex, or national origin. Such action shall include, but not be limited to, the following: employment, upgrading, demotion, or transfer, recruitment or recruitment advertising; layoff or termination; rates of pay or other forms of compensation; and selection for training, including apprenticeship. The state agrees to post in conspicuous places, available to employees and applicants for employment, notices to be provided by the secretary setting forth the provisions of this Equal Opportunity clause.

B. The State will, in all solicitations or advertisements for employees placed by or on behalf of the state, state that all qualified applicants will receive consideration for employment without regard to race, color, religion, sex, or national origin.

c. The state will send to each labor union or representative of workers with which he has a collective bargaining agreement or other contract or understanding, a notice to be provided by the secretary, advising the labor union or workers' representative of the State's commitments under this Equal Opportunity clause, and shall post copies of the notice in conspicuous places available to employees and applicants for employment.

D. The State will comply with all provisions of Executive Order No. 11246 of september 24, 1965, and of the rules, regulations, and relevant orders of the secretary of Labor.

E. The state will furnish all information and reports required by Executive order No. 11246 of September 24, 1965, and by the rules, regulations, and orders of the secretary of Labor, or pursuant thereto, and will 
permit access to his books, records, and accounts by the contracting agency and the Secretary of Labor for purposes of investigation to ascertain compliance with such rules, regulations, and orders.

F. In the event of the state's noncompliance with the Equal Opportunity clause of this Agreement or with any of the said rules, regulations, or orders, this Agreement may be cancelled, terminated, or suspended, in whole or in part, and the state may be declared ineligible for further Government contracts in accordance with procedures authorized in Executive Order No. 11246 of september 24, 1965, and such other sanctions may be imposed and remedies invoked as provided in Executive Order No. 11246 of September 24, 1965, or by rule, regulation, or order of the secretary of Labor, or as otherwise provided by law.

G. The state will include the provisions of paragraphs (A) through (G) in overy subcontract or purchase orier unless exempted by rules, regulations, or orders of the Secretary of Labor issued pursuant to section 204 of Executive Order No. 11246 of September 24, 1965, so that such provisions will be binding upon each subcontractor or vendor. The state will take such action with respect to any subcontract or purchase order as the contracting agency may direct as a means of enforcing such provisions, including sanctions for non-compliance. Provided, however, that in the event the state becomes involved in, or is threatened with, litigation with a subcontractor or vendor as a result of such direction by the contracting agency, the state may request the United States to enter into such litigation to protect the interests of the United States.

XI. EXAMINATION OF RECORDS

A. The state agrees that the Comptroller General of the United States or any of his duly authorized representatives shall, until the expiration of three years after final payment under this Agreement or such lesser time specified in either Appendix $M$ of the Armed Services Procurement Regulation or the Federal procurement Regulations, Part 1-20, as appropriate, have access to and the right to examine any directly pertinent books, documents, papers, and records of the state involving transactions related to this Agreement.

B. The state further agrees to include in all its subcontracts hereunder a provision to the effect 
that the subcontractor agrees that the Comptroller General of the United States or any of his duly authorized representatives shall, until the expiration of three years after final payment under the subcontract or such lesser time specified in either Appendix $M$ of the Armed Services Procurement Regulations, Part $1-20$, as appropriate, have access to and the right to examine any directly pertinent books, documents, papers, and records of such subcontractor, involving transactions related to the subcontract. The term "subcontract" as used in this clause excludes (1) purchase orders not exceeding $\$ 10,000$ and (2) subcontracts or purchase orders for public utility services at rates established for unform applicability to the general public.

C. The periods of access and examination described in $B$ and $C$, above, for records which relate to (1) litigation or the settlement of claims arising out of the performance of this Agreement, or (2) costs and expenses of this Agreement as to which exception has been taken by the Comptroller General or any of his duly authorized representatives, shall continue until such appeals, litigation, claims, or exceptions have been disposed of.

D. The State shall report to the Secretary promptly and in reasonable written detail, each notice or claim of patent or copyright infringement based on the performance of this Agreement of which the State has knowledge.

E. In the event of any claim or suit against the Government, on account of any alleged patent or copyright infringement arising out of the performance of this Agreement or out of the use of any supplies furnished or work or services performed hereunder, the state shall furnish to the Government, when requested by the secretary, all evidence and information in possession of the state pertaining to such suit or claim. Such evidence and information shall be furnished at the expense of the Government. 
F. The DCE may request, and the state shall, transfer to the custody of DOE copies of certain records maintained by the State pursuant to this Agreement when the DOE determines that the records possess longterm retention value. In order to avoid duplicate recordkeeping, the DCE may make arrangements with the state to retain any records that are continuously needed for foint use.

G. Upon request by the State, the DCE shall transfer to the state copies of proposals, vouchers, supporting documentation and any technical and financial reports submitted by prime contractors selected to perform work under this Agreement, when the State determines trat the records possess long-term retention value. In order to avoid duplicate recordkeeping, the state may make arrangements with the DOE to retain coples of any such records that are continuously needed for joint use.

XII. TEFM AND TERMINATION

A. This agreement shall take effect upon the date of concurrence of the Commission with the terms and conditions thereof.

B. Either DOE or the State may terminate this Agreement in whole, or in part, when both parties agree that continuation of the profect would not produce beneficial results commensurate with the further expenditure cf funds. The two parties shall agree upon the termination conditions, including the effective date and, in the case of partial terminations, the portion to be terminated. Neither party shall incur new ohligations for the terminated portion after the effective date. The parties shall cancel as many outstanding obligations as possible. Full credit shall be allowed by each party for noncancelable obligations properly incurred by the other party prior to the termination.

c. Either the DOE C.r the State may terminate the Agreement in whole, or in part, at any time before the date of completion, whenever the contracting officer determines that the respective party has failed to comply with the conditions of the Agreement. The contracting officer shall promptly notify the: respective party in writing of the determination and the reasons for the termination, together with the effective date of the termination if the farty does not resume compliance with the conditions of the Agreement. 
D. After receipt of a Notice of Termination by either party, the DOE and the state shall close out this Agreement in accordance with the terms and conditions of Article XXIII of this Agreement; Provided, that the DOE may, in its discretion, continue unilateral performance of this Agreement, including performance of the state's responsibilities, without cost to the State, until such time as the remedial action contemplated by this Agreement and the Remedial Action Plan is completed.

B. This agreement shall expire at such time as the DOE and the State mutually agree in writing that the objectives of the remedial action program have been met, or seven years from the date of promulgation of standards by the Administrator as provided for in this Agreement, whichever is earlier; provided, however, that the parties may extend this Agreement by mutual written consent.

c. The Secretary, upon written notice to the State, may terminate their Agreement in the event the State is in default because of a material breach which is not cured within 60 days after receipt of a written notice of default from the secretary.

D. The State, upon written notice to the Secretary, may terminate this Agreement in the event the DOE is in default because of a material breach which is not cured within 60 days after recelpt of a written notice of default from the state.

E. In the event of termination, all obligations of the terminatting party under this Agreement, except those outstanding at the time of notice of termination, shall cease.

F. Neither the DOE nor the State shall be considered in default of this Agreement because of delay in performance for reasons beyond its control including, but not restricted to, acts of God or the public enemy, fire, floods, epidemics, quarantine restrictions, strikes, freight embargoes, or unusually severe weather.

G. In the event appropriated funds are not available to the State to carry out this Agreement:

1. DOE shall have the right to continue unilateral performance of this Agreement, including performance of the State's responsibilities, without cost to the state, until such time as the remedial action contemplated by this Agreement and the Remedial Action Plan is completed. 
2. DOE and the State shall close out this Agreemert pursuent to Article XXIII hereof.

H. In the event appropriated funds are not available to the DOE to carry out the Act or this Agreement, the DOE and the State shall close out this Agreement pursuant to Article XXIII of tris Agreement and such other procecures as mutually agreed to in writing by the parties.

XIII. DISPUTES

A. Except as otherwise provided in this Agreement, any dispute concerning a question of fact arising under this Agreement which is not disposed of by Agreement shall be decided by the DOF. Contracting officer, who shall reduce his decision to writing and mail, or otherwise furnish a copy thereof to the state The decision of the DOE Contracting Cfficer shall be final and conclusive unless within 60 days from date of receipt of such copy, the state mails, or delivers a writter notice of appeal to the Department of Energy Financial Assistance Appeals Board in accordance with 10. CFR Part 1024 (See Rule 1). The decision of the Department of Energy Financial Assistance Appeals Board shall be final and conclusive unless determined by a court of competent jurisdiction to have been fradulent, or capricious, or arbitrary, or so grossly erroneous as necessary to imply bad faith, or not supported by substantial evidence. In connection with any appeal proceeding under this clause the State and the DOE shall be afforded an opportunity to be heard and to offer evidence in support of its appeal. Pending final decision of a dispute hereunder, the state and the Government shall proceed diligently, wi.th the performance of the Agreement and in accordance wi.th the DOE Contracting officer's decision.

B. This "Disputes Clause" does not preclude consideration of law questions in connection with decisions provided for in paragraph (A) above; provided, that nothing in this Agreerent shall be construed as making final the decision of any administrative official, representative, or bcrard, based on a question of law. 


\section{PROCUREMENT AND SUBCONTRACTING}

Unless otherwise agreed by the DOE and the state in writing, and except as provided in this Agreement, the DOE shall procure, in accordance with applicable DOE procurement policies and procedures and existing Federal law, all supplies, equipment, construction and services necessary for the performance of this Agreement and the Remedial Action Plan. The applicable standards and guidelines for any procurement by the state of supplies, equipment, construction and services pursuant to this Agreement shall be Attachment 0 to the Office of Management and Budget (OMB) Circular A-102, as that attachment was revised by OMB on August 1,1979 , and published in the Federal Register, Volume 44, No. 159, August 15, 1979, pp. 47874-47878, except as provided in Article XXVI below, and provided that such standards shall not apply to the state's acquisition of property pursuant to Article $V$ of this Agreement.

'XVI. ESTIMATED COST

The total estimated cost of this project will be determined when the Remedial Action Plan (Appendix B) is approved by the parties following the Environmental Protection Agency's promulgation of standards, pursuant to section 275 of the Atomic Energy Act of 1954, as amended.

If the Secretary determines that the state should acquire title to or a lesser interest in real property, adequate funds will be obligated to pay for the Federal share of such real property.

No federal funds are obligated by the execution of this Cooperative Agreement; however, subject to the availability of appropriated funds, DOE agrees to pay ninety (90) percent and the state agrees to pay 10 percent of allowable costs required by the Remedial Action Plan provided:

(1) the Plan has been approved by DOE, the state and the Commission;

(2) the costs of such remedial action do not exceed amounts to be mutually agreed upon in the Remedial Action plan as amended from time to time; and

(3) the State Legislature has appropriated, or the State has otherwise allocated sufficient funds to cover its annual share of the remedial action, or other expenses under this Agreement. 
DOE further promises to pay ninety $(90)$ percent of allowable costs associated with acquisition of real property and residual radioactive materials in accordance with Article $V$ hereof, relocation payments in connection with acquisition or remedial action, and transfer, by the State to DOE, of title to real property and residual radioactive materials, provided:

(1) DOE has approved the agreement for the purchase of the property pursuant to Article XVIII of this Agreement, and

The State Legislature has appropriated or the State has otherwise allocated sufficient funds to cover its share of the acquisition of real property.

XVI. REPORTING REQUIREMENTS

A. DOE shall inform the state in writing of the status of activities under this Agreement as major milestones are reached but in no event less frequently than quarterly.

B. The State shall submit to the DOE Contracting officer, as directed, progress and financial reports of its activities in the acquisition of real property under this Agreement.

c. The state shall submit annually, commencing one year from the effective date of this Agreement, to the DOE Contracting officer, OMB Standard Form 269, a Financial Status Report, a copy of which is attached as Appendix I covering amounts paid to the state by DOE pursuant to this Agreement. DOE shall prescribe whether the reports shall be on a cash or accrual basis. If the DOE requires accrual information and the State's accounting records are not normally kept on the accrual basis, the state shall not be required to convert its accounting system but shall develop such accrual information through an analysis of the documentation on hand. The state shall submit a final Financial Status Report upon close out of this Agreement in accordance with Article XXIII hereof. The State shall submit the OMB Standard Form 269, original and two copies, to the DOE Contracting Officer no later than 90 days after the end of the specified reporting period for the annual and final reports. Reasonable extensions to reporting due dates may be granted by the DOE Contracting officer upon written request of the state. 
D. The State shall supply to DOE such additional financial information as is requested in writing by DOE to comply with Congressional requirements.

E. All standard forms required to be submitted by the State pursuant to this Article shall be provided to the State by the DOE Contracting officer upon request.

F. The reports or other information to be submitted by the State to the DOE Government shall be submitted without restricted markings or other conditions relating to use or disclosure.

XVII. PROJECT MANAGEMENT

A. Real Property Acquisition Phase of the Project

Pending the promulgation of the EPA standards and the development of the Remedial Action Plan, the State may be authorized by the Secretary to initiate action leading to the acquisition of real property pursuant to Article $V$ of this Agreement. The state will not execute the acquisition Agreement or otherwise acquire title to any real property without written authorization of the DOE Contracting Officer.

B. Remedial Action Plan Dcvelopment Phase

DOE will develop a Remedial Action plan following the promulgation by EPA of standards of general application pursuant to Section 275 of the Atomic Energy Act of 1954 as amended, and will submit it to the state and the commission for review and comment. This plan will include a detailed cost estimate, which will be used to project the financial liabilities of the parties if they choose to proceed with the remedial actions. Prior to implementation of the Remedial Action Plan, DOE and the state will endeavor to insure sufficient authorization of funds from the Congress and the Utah state Legislature so as to permit the completion of the work under the Plan.

Remedial actions will not begin until both parties and the Commission have accepted the Remedial Action Plan, and the state and DOE have obligated sufficient funds to complete the scope of work projected for not less than the first fiscal year of the implementation of the Remedial Action Plan. 
C. Remedial Action Phase

Unless otherwise agreed by the DOE and the state in writing, DOE will perform all remedial actions under the direction of a DOE Contracting officer pursuant to the Remedial Action Plan, keeping the state advised in writing as to the status of major milestones and cost iricurred.

XVIII. LOCAL ADVISORY COMMITTEES

The DOE shall not be a member of any local advisory committees established in connection with the remedial action to be performed under this Agreement tor the purpuse uf providing information to and receiving information from the citizens of the localities affected by such remedial action. The DOE shall however, make every reasonable effort to interface with any such committee to the extent. requested by the state or the Committee. No costs associated with any advisory committee shall be allowable costs under this Agreement.

XIX. OTHER REMEDIES

Nothing in this Agreement shall prevent the secretary from enforcing any provision of Title $I$ of the Act, any regulation promulgated thereunder, or any provision of this Agreement, by injunction or other equitable remedy, or as otherwise provided by section 110 of the Act.

XX. ENTIRE AGREEMENT

This written Agreement and the attached Appendices constitutes the entire Agreement of the parties hereto. No representations, promises, terms, conditions, or obligations whatsoever referring to the subject matter hereof, other than those expressly set forth herein, shall be of any binding legal force or effect whatsoever.

XXI. CONCURRENCES AND CONSULTATIONS

Wherever in this Agreement or in the Act a concurrence from or consultation with another Government agency is required, the DOE shall seek such concurrence and be responsibie for undertaking such consultation.

XXII. CLOSEOUT PROCEDURES

A. As of the date of receipt of a Notice of Termination pursuant to Article XII of this Agreement, or on the date of expiration of the period of performance or failure of one party to appropriate funds as provided in Article XII of this Agreement: 
1. The parties shall:

a: Stop performance under this Agreement on the date and to the extent specified in the Notice of Termination or on the date when the period of performance expires;

b. Place no further orders and make no further subcontracts or other Agreements, for materials, service or property except as may be necessary for completion of such portion of the work under this Agreement as is not terminated by any Notice of Termination;

c. Terminale all orders, subcontracts, or other agreements entered into in performing this Agreement, to the extent that they relate to the performance of work terminated by the Notice of. Termination or terminated by the expiration of the period of performance of this Agreement;

d. Settle all outstanding liabilities and all

- claims arising out of such termination of orders, subcontracts and agreements, the cost of which would be reimbursable, in whole or in part, as a project cost in accordance with the provisions of this Agreement;

e. In the event of partial termination, complete

. performance of such part of the work which is not terminated by the Notice of Termination shall be completed;

f. Take such action as may be necessary or as the DOE Contracting officer may direct for the protection and preservation of the property related to this Agreement which is in the possession of the state and in which the Government has or may acquire an interest.

2. The DOE shall, upon written request by the state, make prompt payment to the state pursuant to Article III of this Agreement, for any outstanding reimbursable allowable costs incurred by the State not yet paid by the DOE as required by this Agreement.

3. The State shall, upon.written request by the DOE, make prompt payment to the DOE pursuant to Article. IV of this Agreement, for its outstanding share of costs incurred by the DOE and the state in performance of this Agreement. 
4. The state shall immediately refund to the DOE any balance of cash advanced to the state that is not authorized by the DOE Contracting officer to be retained by the state.

5. The state shall provide to DOE, within 90 days after either the date of expiration of the period of performance, or the date of termination of performance, or at such time designated by the DOE Contracting officer, all financial performance, and other reports required pursuant to this Agreement. The DOE Contracting offieer shall grant extensions when requested by the state if such extensions are reasonable. An independent audit may be requested by either party.

6. In the event a final audit has not been performed prior to closeout of this Agreement, each party. shall, until such final audit is performed, retain the right to recover any outstanding share of allowable costs from the other party.

7. As directed by the DOE Contracting officer in writing, consistent with this agreement, transfer to the Government property acquired by the state pursuant to this Agreement.

Upon termination or at the expiration of the period of performance, the state shall proceed immediately with the performance of the above obligations notwithstanding any delay in determining or adjusting the amount of the allowable project costs.

XXIII. STATE FINANCIAI, MANAGEMENT SYSTEM

The state shall assure that its financial management systen provides for:

A. Accurate, current and complete disclosure of the financial results of the State's participation in the remedial action program, carried out pursuant to this Agreement and the Remedial Action Plan. Should the DOE Contracting officer require the State to report on an accural basis, the state shall not be required to establish an accrual accounting system but shall develop such accrual data on required reports on the basis of an analysis of the documentation on hand. 
B. Records that identify adequately the source and application of funds for activities supported pursuant to this Agreement. These records shall contain information pertaining to authorizations, obligations, unobligated balances, assets, liabilities, outlays, and program income.

c. Effective control over and accountability for all funds, property, and other assets. The state shall adequately safeguard 11 such assets and shall assure that they are used solely for authorized purposes.

D. Comparison of actual outlays with budgeted or otherwise authorized amounts.

E. Procedures to minimize the time elapsing between transfer of funds from the U.S. Treasury and the disbursement by the State, whenever funds are advanced by the Government.

F. Procedures for identifying the reasonableness of costs.

G. Accounting records that are supported by adequate and reasonable source documerilalion.

H. Examinations in the form of audits which meet the requirements set forth in Office of Management and Budget (OMB) Circular A-102, Attachment P, as that Attachment was revised by OMB effective october 22,1979 , and published in the Federal Register, Volume 45, No. 65, April 2, 1980; pp. 21875-21878, and which are in accordance with the "Guidelines for Financial and Compliance Audits of Federal Assisted Programs," issued by the United States General Accounting Office.

I. A systematic method to assure timely and appropriate resolution of audit findings and recommendations.

XXIV. CASH DEPOSITORIES

Any money advanced to the state under the Agreement must be deposited in a bank with Federal Deposit Insurance Corporation (FDIC) insurance coverage and any balance exceeding the FDIC coverage must be collaterally secured in a manner approved by the DOE Contracting officer. 
XXV. ADDITIONAL GENERAL PROVISIONS

To the extent and only to the extent that the state is authorized by the DOE Contracting officer and agrees to procure supplies, equipment, construction, or services under this Agreement each of the following clauses are applicable:

(A) Inspection

The DOE through any authorized representative, has the right at all reasonable times, to inspect, or otherwise evaluate the work performed or being performed hereunder and the premises in which it is being performed. If any inspection, or evaluation is made by the DOE on the premises of the state or a subcontractors, the state shall provide and shall require its subcontractors to provide all reasonable facilities and assistance for the safety and convenience of the DOE representatives in the performance of their duties. All inspections and evaluations shall be performed in such a manner as will not unduly delay the work.

(B) Assignment of Claims

Pursuant to the provisions of the Assignment of Claims Act of 1940, as amended (31 U.S.C. 203, 41 U.S.C. 15), if this Agreement provides for payments aggregating $\$ 1,000$ or more, claims for money due or to become due the state from the DOE under this Agreement may be assigned to a bank, trust company, or other financing institution, including any Fcdcral lending agency, and may thereafter be further assigned and reassigned to any such institution. Any such assignment or reassignment shall cover all amounts payable under this Agreement and not already paid, and shall not be made to more than one party, except that any such assignment or reassignment may be made to one party as agent or trustee for two or more parties participating in such financing. Unless otherwise provided in this Agreement, payments to an assignee of any monies due or to become due under this Agreement shall not, to the extent provided in said Act, as amended, be subject to reduction or setoff.

\section{(c) Convict-Labor}

In connection with the performance of work under this Agreement, the state agrees not to employ any 
person undergoing sentence of imprisonment except as provided by Public Law 89-176, September 10, 1965 (18 U.S.C. 4082 (c) (2)) and Executive Order 11755, December 29, 1973.

(D) Audit

(a) Examination of Costs. The State shall maintain, and the DOE Contracting officer or his representatives shall have the right to examine books, records, documents, and other evidence and accounting procedures and practices, sufficient to reflect properly all direct and indirect costs of whatever nature claimed to have been incurred and anticipated to be incurred for the performance of this Agreement. Such right of examination shall include inspection at all reasonable times of the State's facilities, or such parts thereof, as may be engaged in the performance of this Agreement as to cost or pricing data submitted by the state.

(b) Cost or pricing data. : If the state submitted cost or pricing data in connection with the pricing of this Agreement or any other change or modification thereto, unless such pricing was based on adequate price competition, estabished catalog or market prices of commercial items sold in substantial quantities to the general public, or process set by law or regulation, the DOE Contracting Officer or his representatives who are employees of the United States Government shall have the right to examine all books, records, documents, and other data of the state related to the negotiation, pricing or performance of such Agreement, change or modification, for the purpose of evaluating the accuracy, completeness and currency of the cost of pricng data submitted. Additionally, in the case of pricing any change or modification exceeding $\$ 1,000,000$ to formally advertised agreements, the comptroller General of the United States or his representatives who are employees of the United States Government shall have such rights. The right of examination shall extend to all documents necessary to permit adequate evaluation of the cost or pricing data submitted, along with the computations and projects used therein. 
(c) Availability

The materials described in (a) and (b) above, shall be made available, at all reasonable times, for inspection, audit or reproduction, until the expiration of three years from the date of final payment under this Agreement or such lesser time specified in part 1-20 of the Federal Procurement Regulations (4I CFR Part 1-20) and for such longer periods, if any, as is required by applicable statute, or by other clauses of this contraat, or by (1) and (2) below:

(1) If this Agreement is oompletely or partially terminated, the records relating to the work terminated shall be made available for a perlod of three years from the date of any resulting final settlement.

(2) Records which relate to appeals or disputes or litigation or the settlement of claims arising out of the performance of this Agreement, shall be made available until such appeals, litigation, or claims have been disposed of.

(d) The State shall insert a clause containing all the provisions of this clause, including this paragraph (d), in all subcontracts hereunder except altered as necessary for proper identification of the contracting parties and the DOE Contracting officer under this Cooperative Agreement.

(E) Clean Air and Water

The State agrees as follows:

(1) To comply with all the requirements of section 114 of the clean Air Act, as amended $(42$ U.S.C. 1857, et. seq., as amended by P.I. 91604 ) and secton 308 of the Federal Water Pollution Control Act (33 U.S.C. 1251, et. seq., as amended by P.I. 92-500), respectively, relating to inspection, monitoring, entry, reports, and information, as well as other requirements specified in section 114 and Section 308 of the Air Act and the water Act, respectively, and all regulations and guidelines issued thereunder before the award of this Agreement. 
(2) That no portion of the work required by this Agreement will be performed in a facility listed on the Environmental Protection Agency List of Violating Facilities on the date when this Agreement was awarded unless and until the EPA eliminates the name of such facility or facilities from such listing.

(3) To use his best efforts to comply with clean air standards and clean water standards at the facility in which the Agreement is being performed.

(4) To insert the substance of this clause into any nonexempt contract, including this paragraph (e) (4).

The terms used in this provision have the following meanings:

(1) The term "Air Act" means the clean Air Act, as amended (42 U.S.C. 1857, et. seq., as amended by P.L. 91-604).

(2) The term "Water Act" means Federal water Pollution Control Act, as amended ( 33 U.S.C. 1251, et. seq., as amended by P.I. 92-500).

(3) The term "clean air standards" means any enforceable rules, regulations, guidelines, standards, limitations, orders, controls, prohibitions, or other requirements which are contained in, issued under, or otherwise adopted pursuant to the Air Act or Executive Order 11738, an applicable implementation plan as described in section 110 (d) of the Clean Air Act (42 U.S.C. $1857 c-5(d))$, an approved implementation procedure or plan under Sectionlll(c) or Section 111 (d), respectively, of the Air Act $(42$ U.S.C. $1857(c)-(6(c)$ or (d)), or an approved implementation procedure under section $112(d)$ of the Air Act 142 U.S.C. $1857 c-7(d))$. 
(4) The term "clean water standards" means any enforceable limitation, control, condition, prohibition, standard, or other requirement which is promulgated pursuant to the Water Act or contained in a permit 1ssued to a discharger by the Environmental Protection Agency or by a state under an approved program, as authorized by Section 402 of the Water Act (33 U.S.C. 1342), or by local government to ensure compliance with pretreatment regulations as required by section 307 of the water Act (33 U.S.C. 1317).

(5) The term "compliance" means compliance with clean air or water staruditas during and after remedial action. Compliance shall aleo mean compliance with a schedule or plan ordered or approved by a court of competent jurisdiction, the Environmental Protection Agency on an air or water pollution control agency in accordance with the requirements of the Air Act or Water Act and regulations issued pursuant thereto.

(6) The term "facility" means any building, plant, installation, structure, mine, vessel, or other floating craft, location, or site of operations, owned, leased, or supervised by a participant or subcontractor, to be utilized in the performance of an agreement or subcontract. Where a location or site of operations contains or includes more than one building, plant, installation, or structure, the entire location or site shall be deemed to be a facility except where the Director, Office of Federal Activities, Environmental Protection Agency, determines that independent facilities are collocated in one geographical area.

(F) Flood Insurance

State will comply with the flood insurance purchase requirements of Section 102 (a) of the Flood Disaster Protection Act of 1973, Public Iaw 93-234, 87 Stat. 975, approved December 31, 1976.

(G) Permits and Licenses

Except as otherwise agreed to by the DOE Contracting officer, the state shall procure all necessary permits or licenses and abide by all applicable laws, regulations and ordinances of the United states and of the state territory, and political subdivision in which the work under this Agreement is performed. 
(H) Authorization and Consent

The DOE hereby gives its authorization and consent for all use and manufacture of any invention described in and covered by a patent of the United States in the performance of this Agreement or any part hereof or any subcontract hereunder (including all lower-tier subcontracts).

\section{(I) Utilization of Labor Surplus Area Concerns}

(a) It is the policy of the DOE to award agreements to labor surplus area concerns that agree to perform substantially in labor surplus areas, where this can be done consistent with the efficient performance of the Agreement and at prices no higher than are obtainable elsewhere. The state agrees to use its best efforts to place its subcontracts in accordance with this policy.

(b) In complying with paragraph (a) of this clause, the state in placing its subcontracts shall observe the following order of preference: (1) small business concerns that are labor surplus areas concerns, (2) other small business concerns, and (3) other labor surplus area concerns.

(c) (1) The term "labor surplus area" means a geographial area identified by the Department of Labor as an area of concentrated unemployment or under employment or an area of labor surplus.

(2) The term "labor surplus area concerns" means a concern that together with its first-tier subcontractors will perform substantially in labor surplus areas.

(3) The term "perform substantially in a labor surplus area" means that the costs incurred on account of manufacturing, production, or appropriate services in labor surplus areas exceed 50 percent of the contract price. 
(J) Labor Surplus Area Subcontracting Program (applicable. if the Ccintract. exceeds $\$ 500,000)$

(a) The State agrees to establish and conduct a program which will encourage labor surplus area concerns to compete for subcontracts within their capabilities. In this connection, the State sholl:

(1) Designate a liaison officer who will (i) maintain liaiscn with duly authorized represertatives of the fovernment on labor surplus area matters, (ii) supervise compliance with the Utilization of Concerns in Labcr Surplus Area clause, and

(iii) administer the State's "Labor Surplue Area Subcontracting Program";

(2) Provide adequate and timely consideration of the potentialities of laber surplus area concerns in all "make-or-buy" decisions;

(3) Assure the labor surplus area concerns will have an equitable opfortunity to compete for subcontracts particularly by arranging solicitations, time for the preparation of bids, quantities, specifications, and delivery schedules so as to facilitate the participation of labor surplus area concerne;

(4) Maintain records showing the procedures which have been adopted to comply with the policies set forth in this clause and report subcontract awards (see 41 CFR 1-16.804-5) regarding use of Optional Form 61). Records maintained pursuant to this clause will be kept available for review by the DOE until the expiration of one year after the award of the Contract, or for such longer period as may be required by any other clause of this Agreement or by applirable law or regulations; and 
(5) Include the Utilization of Concerns in Labor Surplus Areas clause in subcontracts which offer substantially labor surplus area subcontracting opportunities.

(b) (1) The term "labor surplus area" means a geographical area identified by the Department of Labor as an area of concentrated unemployment or underemployment or an area of labor surplus.

(2) The term "concern located in a labor surplus area" means a labor surplus area concern.

(3) The term "labor surplus area concerns" means a concern that, together with its first tier eubcontractors, will perform substantially in labor surplus areas.

(4) The term "perform substantially in labor surplus areas" means that the costs incurred on account of manufacturing, production, or appropriation services in labor surplus areas exceed 50 percent of the Agreement price.

(c) The state further agrees to insert, in any subcontract hereunder which may exceed $\$ 500,000$ and which contains the Utilization of Concerns in Labor Surplus Areas clause, provisions which shall conform substantially to the language of this clause, including this paragraph (c), and to notify the DOE Contracting officer of the names of such subcontractors.

\section{(K) Limitation of Funds (Cost-Sharing)}

(a) It is estimated that the cost to the DOE for the performance of this Agreement will not exceed the estimated cost to the DOE established pursuant to Article XVI, Estimated cost, and the state agrees to use its best efforts to perform the work specified in the Agreement and all obligations under this Agreement within such estimated cost to the DOE plus the share of the cost of performance agreed to be borne by the State, as set forth in the Agreement.

(b) The amount presently available for payment by the DOE and allotted to this Agreement, the items covered thereby, the DOE's share of the cost thereof, and the period of performance 
which it is estimated the allotted amount will cover, are established pursuant to Article XVI, Estimated cost. It is contemplated that from time to time additional funds will be allotted to this Agreement up to the full estimated cost to the DOE set forth in Article XVI, Estimated Cost. The state agrees to perform or have performed work on this Agreement up to the point at which the total amount paid and payable by the DOE pursuant to the terms of this Agreement approximates but does not exceed the total amount actually allotted by the DOE to the contract.

(c) If at any time the state has reason to believe that the costs which it expects to incur in the performance of the Agreement in the next succeeding 60 days, when added to all costs previously incurred, will exceed 75 percent of the total of the amount then allotted to the Agreement by the DOE plus the state's corresponding share, the state shall notify the DOE Contracting officer in writing to that effect. The notice shall state the estimated amount of additional funds required to continue performance for the period set forth in the Agreement. Sixty days prior to the end of the period specified in the Agreemet the state will advise the DOE Contracting officer in writing as to the estimated amount of additional funds, if any, that will be required for the timely performance of the work under the Agreement or for such further period as may be specified in the Agreement or otherwise agreed to by the parties. If, after such notification, additional funds are not allotted by the end of the period set forth in the Agreement or an agreed date substituted therefor, the DOE Contracting Officer will, upon written request by the State, terminate this Agreement pursuant to the provisions of Article XII, Term and Termination, on such date. If the state, in the exercise of its reasonable judgment, estimates that the funds available will allow the state to continue to discharge its obligations hereunder for a period extending beyond such date, the state shall specify the later date in its request and the DOE Contracting officer, in his discretion, may terminate on that later date. 
(a) Except as required by other provisions of this Agreement specifically citing and stated to be an exception from this clause, the DOE shall not be obligated to reimburse the state for costs incurred in excess of the amount from time to time allotted by the DOE to the Agreement, and the stae shall not be obligated to continue performance under the Agreement (including actions under the termination clause) or otherwise to incur costs in excess of the total of the amount then allotted to the Agreement by the DOE plus the state's corresponding share, unless and until the DOE Contracting officer has notified the State in writing that the amount allotted by the DOE has been increased and has specified in such notice an increased amount constituting the total amount then allotted by the DOE to the Agreement. To the extent that total of the amount allotted by the DOE plus the State's corresponding share exceeds the estimated cost set forth in Article XVI, Estimated Costs, such estimated cost shall be correspondently increased. Any increase in such estimated costs shall be allocated in accordance with the formula set forth in Article XVI, estimated costs, governing such increases. No notice, communication, or representation in any other form or from any person other than the DOE Contracting officer shall affect the amount allotted by the DOE to this Agreement. In the absence of the specified notice, the DOE shall not be obligated to reimburse the State for any costs in excess of total amounts then allotted by the DOE to the Agreement, whether those excess costs were incurred during the course of the Agreement or as a result of termination. When and to the extent that the amount allotted by the DOE to the Agreement has been increased, any costs incurred by the State in excess of the total of the amount previously allotted by the DOE plus the State's corresponding share shall be allowable to the same extent and in the same percentage as if such costs had been incurred after such increase in the amount allotted; unless the DOE Contracting officer issues a termination or other notice and directs that the increase is solely for the purpose of covering terminaton or other specified expenses. 
(e) Nothing in this clause (K), shall affect the right of the DOE or the state to terminate this Agreement. In the event this Agreement is terminated, the DOE and the state shall negotiate an equitable distribution of all property produced or purchased under the Agreement based upon the share of costs incurred by each.

\section{(I) Safety and Health}

(a) The state shall take all reasonable precautions in the performance of lie work under this Agreement to protect the health and assure the safety of employees and the public. The State shall comply with all applicable Federal, State, and local health and safety regulations and requirements including but not limited to those established pursuant to the Occupational Safety and Health Act and with any additional safety and health standards and requirements (including reporting requirements) established by DOE which is to include compliance with DOE Order 5481.1, safety Analysis and Review System.

(b) In the event that the state fails to comply with said regulations and requirements, the DOE Contracting officer, may, without prejudice to any other legal or contractual rights of DOE, issue an order stopping all or any part of the work; thereafter a start order for resumption of work may be issued at the discretion of the DOE Contracting nfficer. In the event of a final determination that the state has failed to comply with said regulations and requirements, the state shall make no claim for an extension of time or for an eçuitable adjustment, compensation or damages by reason of or in connection with such work stoppage.

XXVI. PROVISIONS REIATED TO DOE PERFORMANCE

If DOE procures supplies, equipment, construction of services under this Agreement, each of the following provisions in Article XXVII shall be applicable to DOE:
A. Inspection
B. Clean Air and water
C. Permits and Licensing
D. Safety and Health 
XXVII. EFFECTIVE DATE

This Agreement shall become effective upon the date of concurrence by the Commission and shall remain effective until such time as terminated by the parties in accordance with Article XII, above.

IN WITNESS WHEREOF, the parties have executed this Agreement in several counterparts.

STATE OF

BY :

TITLE :

THE UNITED STATES OF AMERICA

BY: DEPARTMENT OF ENERGY

BY :

TITLE :

CONCURRENCE: NUCLEAR REGULATORY COMMISSION

BY :

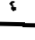

TTLE:

DATE : 


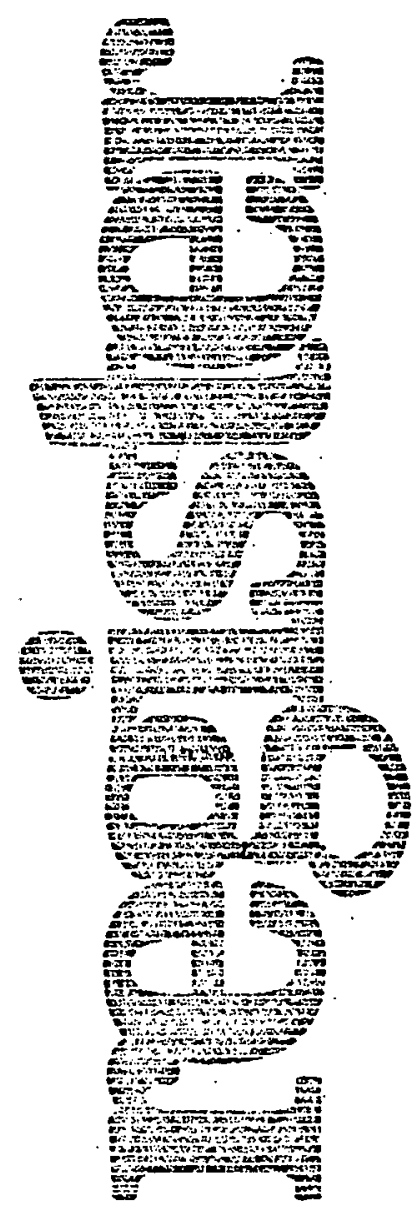

Tuesday
April 22, 1980

\section{Part IV}

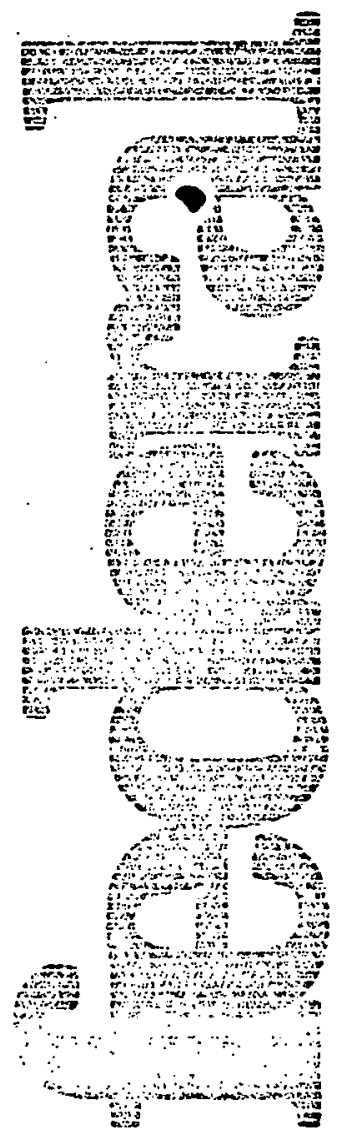

\section{Environmental Protecton Agency}

Iritein Cleanup Standards for Inactive Uranium Processing Siles 


\section{ENVIRONABENTAL PROTECTION AGEINCY}

\section{CFR Part 192}

[FRL 1469-8]

Interim Cleanup Standarcis for Inacive Uranlum Processing Sites

AGEnCY: Environmental Protection Agency.

ACTION: Interim standards.

SUMmary: The Environmental Protection Agency (EPA) is issuing interim standards for cleanup of open lands and buildings contaminated with ressidual radioactive materials (mainly tailings) from inactive uranium processing sites. These standards are also being published simultancously as proposed standards upon which public comment is being snlicited. (See Proposed Cleanup Standards in the Proposed Rules section of the Federal Register.)

EPA has developed these standards pursuant to Section 275(a) of the Alomic Energy Act, as added by Section 206(a) of Pub. L. 95-604, the Uranium Mill Tailingo Radiation Control Act of 1978. Pub. 1. S5-604 requires the Department of Encrgy (DOE) to conduct remedial actions for designated inactive uranium processing sites in accordance with

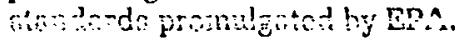
Buildings and land contaminated with tailings pose a continuing threat to public health. Some of these buildings have been found to have radiation levels which are highly dangerous to anyone exposed to them for long times. Pub. I. 95-604 precludes undertaking renedial action before FPA tias promulgated standards. Therefore, we have decided to promulgate interin slandards for cleanup of these npen !sinds and builúings, to permit DUË to take: remedial actions undor Pub. J. S5-6014 to alleviate these problems.

Dares: Effective date: April 2\%, 1900. Comment date: Conments should be received on or before June 23, 1360.

arunes: Comments should be submittell to Dooket No. A-79-25, which is located in the thvironmental Protecidon Agency, Central Locket Section, Fonm 29ans, 401 M Street, SW., Washington, I).C. 200sou. Tise Draft

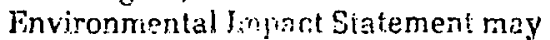
be exanineil at the ientrial Docket Section. Shortly, after we propose disposal stanclards jor inactive proccsing sites, siagle copies of the Draft Envirommente' Impact Stutement nay be cbiainud by writing to the

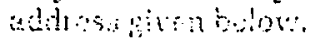

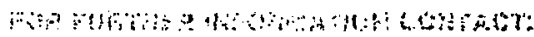
Jor. Stinley lichtman, Criteria and
Standards Division (ANR-460), Office of Radiation Programs, U.S. Envirunmental Protection Agency, Washington, D.C. 20460; telephone number 703-557-8927.

SUPPLEMENTARY INFORMATION: PUISUANT to Section 275(a) of the Atomic Energy Act, as added by Section 206(a) of Pub. L. 95-504, the Uraniun Mill Tailings Radiation Control Act of 2978, EPA has cleveloped standards for the cleanup of open lands and buildings contaminaled with uranium mi!l tailings from inactive proressing sites. Pub. L. 95-60 requires the Department of Energy to conduct remedial actions for designated inactive uranium processing sites in accorcance with standards promulgated by EPA (Section 108(a)(1), 42 U.S.C. Section 7915(a)(1)). However, Pub. L. 95-604 precludes undertaking remedial actions before such siondards are promulgated.

Lands and buildings contaminsted with uraniun mill tallings pose risks to public health. Tho greatest han ard from tailings on open lands is increased levels of radon decay products in buildings. When radon decay products are inhaled, they increase the chance of lung cancer. Exposure to direct gamma radiation and contamination of drinking water and food may also occur.

Tailings usually only pose significant risk to people who are exposed for a lnnetimo. However, some hones and other buildings have been found in which the radon decay product concentration is quite dangerous. There are such buildings, fo: example, in Salt Lake City, and in Canonsburg.

Penncylvania. Several buildings in Salt Lakc City are immediately adjacent to a tailings pile, or have tailings in, under, cr around them. In some of these, incloor radon decay product concentrations excesd the averege riccupetionat concentration limit for uranium miners (0.3 WL W $^{1}{ }^{1}$ Included among these is a fire station in Salt Lakc City, where substantially elevated levels have been measured even when machanical ventilation is used. In Canonsburg, an irdustrial park is now located on an inactiye processing site. Eight huildings leased to cominercial tenants are located direcily over heavily contanimalad Iord. Measuremeils during working hours stow that all buildings have substantially elevated indoor ratinn decay product concentrations. with tho highest average daytine level being 0.4 WL. These levels

\footnotetext{
'A wouling level (WL) is any combination of short-lived yadon decay producta ia one liter of air that will result in the ullinate emissicu of alpha

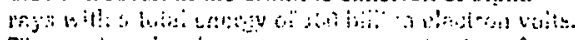

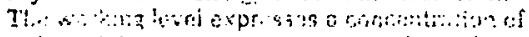

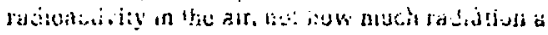
pulson reseives.
}

are dangerous and will continue. To allow DOE to begin remedial action under Pub. L. 95-604 to alleviate these hazards, we have decided to promulgatethese immediateiy effective interim cleanup standards.

Studics of indoor barkground radioactivity in Grand function (Colorado), Niew York State, and New Jersey show that at least 10 percent of houses with basements exceed the interim standord's remedial action level of $0 . C 15$ WL. Because of this, we believe it would often be inpossible to try to reduce leve!s for houses affected by tailings signiflcantly below $0.015 \mathrm{WL}$ by removing the tailings. Thus, it is unlikely that the final standards will be set at a level significantly more stringent than the interim action level of $0.015 \mathrm{WL}$, and remedial actions performed under the interin standard will not have to be redone. ?urthernore, a'though we have not formally solicited public comments on the interin standarus, the Nuclear Regulatory Commission and the Depariment of Energy have been consulted. For these reasons, we bclieve issuing immediately effective interim cleanup standards is justified.

A statement of the research, analysis, and other available information in support of this interim standard is contained in the preamble to the proposed standarcis published elsewhere in the Federal Register today. Additional background material may be found in the Uraft Environmental Impact Statement being made available is Docket No. A-70-25, which is located at the address given above, and in otier information contained in ihat docket. We invite writien comments on these interim standards, and they romain subject to modification in response to such comments and to viows expressed orally at public inecrings (see below).

In addition te the procedures we followed prior to promulgating these interim cleanun siandatcin, we art: conducting the requirad puibic: review process for promulgating inal standards. In the Proposed Rules section of today's Federal Regisier, wo are proposing for comment the cleamup standards for inactive uraniun. processing sites. They are identical to the interim clcanup siandards which are being rade effeclive inmediately. Furthermore, PlA intends to hold public hearings on these proposed cleanup siandards and on proposed stindards for the disposal of lailings from inactive sites. The disposal standards will be proposed for public comment soon, and

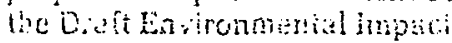

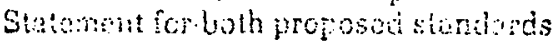
will be made gentrally availate at that 
lime. Therefore, before these proposed cleanup and disposal standards become final, members of the public will have the opportunity to comment in wiving, and to present data, views, ahd arguments at a public hearing.

Noto.-The costs and benefits of these standards are discussed in the Draft Environinental Impact Statement. However, neither our issuance of interim cleanup standards nor the remainder of our program to set remedial action standards for Pub. L. 85-604 require preparation of an economic enalysis under Executive Order 120:4. We expect the costs of the remedial action program in any calendar year to be less than the $\$ 100$ million criterion EPA has established (44 FR 30988-30998, May 29, 1979) for requiring an cconomic analysis.

Dated: April 14, 1080.

Douglas M. Costle, Administrator.

Part 192 is added to Title 40 of the Code of Federal Regulations as follows:

\section{PART 192-ENVIRONMENTAL PROTECTION STANDARDS FOR UAANIUM BAILL TAILINGS \\ Subpart A-[Reserved]}

Subpart B-Environmental Standards for Cleanup of Open Lands and Building3 Contaminated with Residual Radioactive Maferials From Inactive Uranium Proocsosing Siths

Sec:

I92.10 Applicability.

192.11 Definitions.

192.12 Standards.

192.13 Effective date.

\section{Subpart C-Exceptions}

192.20 Criteria for exceptions.

192.21 Remedial actions for exceptional circunstaricoss

Table A [Rs:arved].

Table B.

Authority: Sec. 275, Atomic Energy Act of 195:. (42. U.S.C. 2022), as amended by the Uranium Mill Tailings Radiation Control Act of 1378, Pub. L. 95-604.

\section{Subpart A-[Reserved]}

Subpart B-Environmental Standards for C!eanup of Open Lancis and Buidings Contaminated with Residual Radinactive Materials Fiom inactive Uraniizm Processing Siies

\$132.10 Applicahility.

This subpart applies to open lands" and buildings which are part of any processing site designated by the Secretary of Enargy under Pub. L. 95t04. Section 1(i2. Section 101 of Pub. L. 95-604, states that "processing site" means-

(a) Any site, including the mill, containing residue restondive matcials ai which ail or subetariaily all of the uranium was produced for sale to any Federal agency prior to January 1 , 1971 under a contract with any Federal agency, except in the case of a site at or near Slick Rock, Colorado, unless-

(1) Such site was owned or controlled as of January 1,1978, or is thereafter owned or controlled, by any Federal agency, or

(2) A license (issued by the (ivuclear Regulatory) Commission or its predecessor agency under the. Atowic Fnergy Act of 1954 or by a Siate as permitted under section 274 of such Act) for the production at such site of any uranium or thorium product derived from ores is in effect on January 1, 1978, or is issued or renewed after such date; and.

(b) Any ulher real property or improvement thereon which-

(1) Is in the vicinity of such site, and

(2) Is determined by the Secretary, in consultation with the Commission, to be contaminated with residual radioactive materials derived from such site.

Any ownership or control of an area by a Federal agency which is acquired pursuant to a cooperative agreement under this title shall not be treated as orvnership of control by such agency for purposes of paragraph (a)(1) of this section. A license for the production of any uranium nrodunt from aceidus! redicoctive matoricis s lisil iui ó ireated as a license for frodiction from ores within the meaning of paragraph (a)(2) of this section if such production is in accordance with section 108, b].

\section{§ 192.11 Definitions.}

(a) Unless otherwise indicated in this subpart, all terms shall have the same meaning as defined in Title I of the Uranium Mill Tailings Radiation Control Ac: of 1978.

(b) Remedial action mesus any action performed under Sestion 103 of the Uranium Mill Tailings Radiation Cuntrol Act of 1978.

(c) Open land means any surface or subsurface land which is not a disposal site and is not covered by a builching.

(c) Wro-king Lovel (WL) means any combination of short-lived radon decar products in one liter of ais tha! will result in the ultimate enission of alpha particles with a total energy of 130 billion siectron volts.

(e) Dose cquivalent means absortud dose multiplied by appropriate factors to account for differences in biologica! effectiveness clue to the type and energy of the radiation and other factors. The unit of dose equivalent is the "rem."

(f) Curie (Cj) means the amount of ralivactive nateria! which produses a bilion huclea! transiomations per second. One picocurie (pCi) $=10^{-12} \mathrm{Ci}$.

\section{\$192.12 Standards.}

Remedial actions shall be conducted so as to provide reasonable assurarice that-

(a) The average concentration of radium-225 attributable to residual radioactive material from any designater processirg sitc in any $5 \mathrm{~cm}$ thickness of soils or other ruaterialy on open land within 1 foot of the surface, or in any $15 \mathrm{~cm}$ thickness below 1 fout. silall not exceed $5 \mathrm{pCi} / \mathrm{gin}$.

(b) The levels of radioaclivity in any occupied or occutriable building shall not cxceed either of the values specified in Table $B$ because of residual radioactive materials from any designated processing site.

(c) The cumulative lifelime radiation dose equivalent to any organ of the body of a maximally exposed individual rasulting from tlic prosence of residual radicactive neierials of byproduct materiais shali not exceed the naximum dose equivalent whicl: could occur from radium-220 and its decay preriucts undex paragraphs (a) and (b) of this section.

\section{\$192.i3 Effective date.}

The standards of this subpart shall be effective April 22, 1980.

\section{Subpart C-Exceptions}

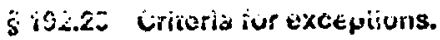

Exceptions to the standards may be juetifiable tinder any of the following ciicumstances:

(a) Public healtt, or safeiy wouid be unavoidably cridangered in attompting to meel vine or more of the reciluirements of Subpart $A$ or Subpart $B$ of this piart.

(b) The goal of environmental protection wiuld b? beller served by not salisfying cleaning rengramants for oper

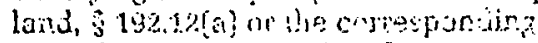

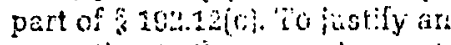
exception to these leruiremente ihere should be a cleariy unf avoratile imbalance betweeni the cuvilonmentel harm and the enveonmental and to: benefits which wouldressit frim implementiug the standird. T! $T$ e likelihond and cxtont of aititul and future humon prestince al the site biay be considered in evaluation these bonefits.

(c) The esimaled costs of rerasdial actions to comply with his: civamp

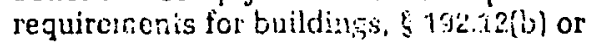
the correspozding purt of $\$ 122.13$ (c), are unreasonably high relative to the benefits. Factor: which nuy be considered in this judgment inclate the period of occupaniey, the redialion ievels

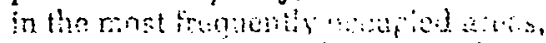

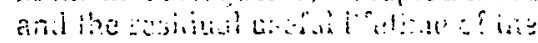
Luilding. "li!s caterion can oug bn used 
when the values in Table B are only slightly exceeded.

(d) There is no known remedial action to meet one or more of the requirements of Subpart A or Subpart B of this part. Destruction and condemnation of buildings are not considered remedial ections for this purpose.

8 192.21 nemedial actions for exceptlonal circumstances.

Section 108 of Fủ. L. 95-004 requires the Secretary of Energy to select and perform remedial actions with the concurrence of the Nurlear Regulatory Commission and the full participation of any State which pays part of the cost. end in consultation, as appropriate, with affected Indian tribes and the Secretary of the Intcior. Under exceptional. circumstances satisfying one or more of the conditions 192.2.0 (a), (b), (c), and (d), the Department of Energy may select and perform remedial ections, according to the procedures of Sec. 108, which come as close to meeting the standard to which the exception applies as is reasonable under the exceptional circumstances. In doing so, the Department of Energy shall inform any private owners and occupants of. affected properties and request their comments on the selected remedial actions. The Department of Energy shall nrevife any such remments to th:o partiea involved in implementing Sec. 108 of Pub. I. 95-604. The Depertment of Energy shall also inform the Environmental Frolection Agency of remedial actions for exceptional circumsiances under Sulspart $C$ of thio rule.

Table A-[Pesened]

Table $\mathrm{B}$

Average ennual indoer faden cecay preduct cor cenuation-inckuding backgrourd $\mathrm{N}$. D )................ 0.015 insoor garima radieition-abovg sackground

(millisoentgen per hour........................................... 0.02 [FR Lioc. 60-12:305 Filed 4-21-63. (245 am]

GILLING COIDE 5560-01-N 


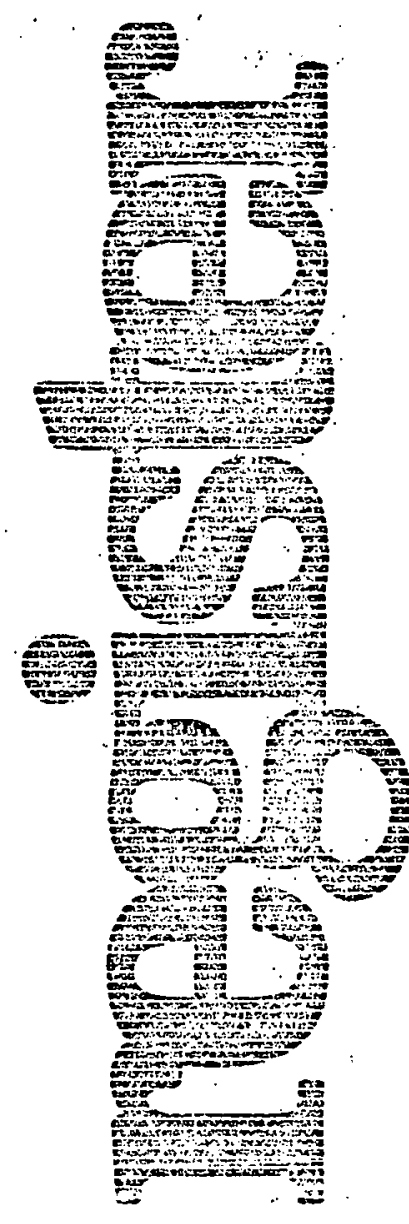

\section{Tuesday \\ April 22, 1980}

Part $\mathrm{V}$

Eพviromm Protechon Agenmy

Proposed Cleanup Stanciards for Inactive Uranium Prooesengs Sibes

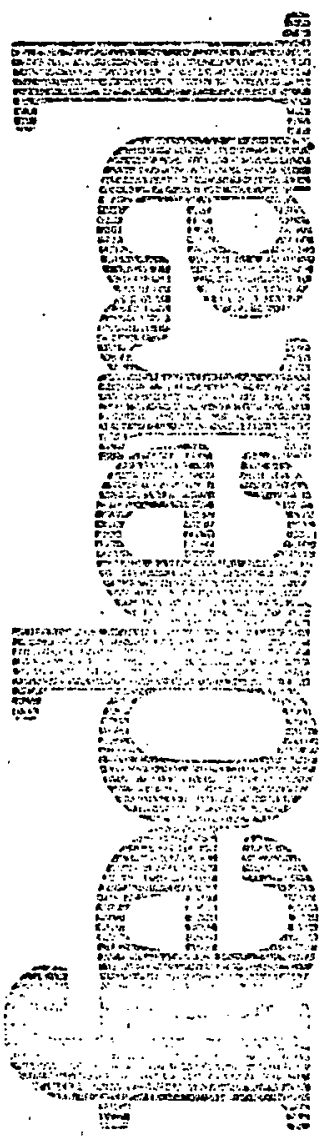




\section{ENVIRONMENTAL PROTECTION AGENCY}

\section{CFR Part 192 \\ [FRL 1454-8]}

\section{Proposed Cleanup Standards for Inactiv: Uranium Processing Sites; Invitation for Comment}

AGENCY: U.S. Environmental Protection Agency.

ACTION: Proposed cleanup standards.

SURMaRY: The Environmental Protection Agency (EPA) is publishing for comment proposed environmental standards for the cleanup of open lands and buildings contaminated with residual radicactive Inaterials (mainly tailings) from inactive uranium processing sites. Thesc standards are being made immediately effective on an intcrim basis. (See Interim Standards published in tiie Final Rulcs section of the Federal Register.) EPA has developed these standards pursuant to Section 275(a) of the Atomic Energy Act, as added by Section 200(a) of Pub. L. 95-604. Title I of Pub. L. 95-604 requires the Department of Energy to conduct remedial actions for designated inactive uranium processing sites in accordance with standards promulgated bì EFÁ.

१ine piuposis: cleanup sianưards require iha? remedial actions lower the concentration of radium in contaminated soil below specified levels. Limits are also proposed on the radon decay product concentration and gamma radiation in occupied or occupiable buildings affected by tailings.

Additional background material is given in a Draft Environmental Impact Statement which En $i$ is culcring in the Dockei simultancously with this notice. In addition to this request for written comments, the Agency will shortly publish for commint proposed stanciards for the disposal of tailings from inactive processing sites. Shorlly thereafter, we will announce the time and place of hearings at which interested persens may preserit comnients on the proposed cleenup and dispesal standards.

Dare: Commints should be received on or before June 23, 1890.

Aodsess: Comments should be submitted to Docket No. A-70-25, which is located in the Environimental Protection Agency, Central Docket Section, Room 2 S03B, sili M! Street. S.W., Washington, D.C. 20aro. Shortly, ?tur

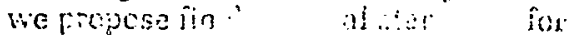

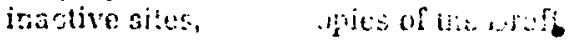

Environmental Impact Statement may be obtained by writing to the address given below.

FOR FUATHER INFORMATION CONTACT: Dr. Stanley Lichtman, Criteria \& Standards Division (ANR-460), Office of Radiation Programs, U.S. Environmental Protection Agency, Washington, D.C. 20460; tclcphone number 703-557-8927. SUPPLEMENTARY INFORAATION:

\section{Introduction}

The proposed cleonup standards are part of the standards EPA is developing at the direction of Congress for remedial actions to protert public health. safety, and the environment from uranium inill. tailinge from inactive pronessing siles. There are two major parts of the remedial actions: cleanup and disposal. The cleanup process reduces the potential health ronseguences of tailings which have been dispersed from their. original location on a tailings pile, or used in construction. Disposal is the operation which places the tailings themselves in a condition which will be safe for a long time. The disposal site may be at the original location of the tailings, or a new one.

This notice announces proposal of cleariup standards (Subpart B) for the inartive nroressing sites covered under

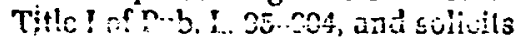
public comment on thewe standards. They are also being made inmediately effective as interim standards for the remedial action program authorized by Title 1 , pending completion of the public comment and hearing process contemplated by Pub. L. 95-604. We are continuing to develop standards for disposal of tailings from inactive processing sites (Subpart A), and standards for tailings at active sites. We expect to propose disposal standards for inactive processing siles shortly, and to solicit public comments at that time. After they are published, we will hold hearings covering the proposed cleanup and disposal standards for inactive sites.

In order to carry cul our responsibility under Pub. L. 95-904 to oct senerally applicable standarás for uranium mill tailing:, we liave examiied ineir polintial public heal' and crvironmiental impacts. 'This exannation establisted the radiological and nonradiolcgical rharacteristics of taiings which requile control.

Tailings are hazarious primarily because: (1) Breathing radon and its decay products exposes the lunis to alpha poricles; (2) the boug may he

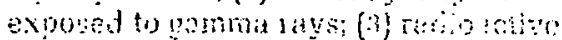
máerials ard nostadouctive toxic clements from tailings may be swallowed with food and water. The radiation hazard from tailings lasts for many thousands of years, and noriradioactive toxic elements persist indefinitely. The longevity of these hazards played a major role in determining the proposed standards.

The most commonly used unit of exposure to radion decay products is working livel months (WIM). ${ }^{2}$ Gamma radiation doses arc usually expressed in units of rads. ${ }^{2}$

Although the available data are consistent with nany models, we believe that a linear, nonthreshold doseeffect relationship is a reasonable mcdel fur deriving estimates of riok to the general public. This model assumes that any radiation dose prcocrito oomo rick to humans and that the risk is directly proportional to the damage

demonstrated at higher doses. We recognize, howover, that the data. preclude neither a threshola for some types of radiation below which there is no damage to people, nor the possibility that low doses may do more damage to some people than the linear model implies.

The main danger from breathing radon decay products is induction of lung cancer by aipha radiation. Gamma rays, while less hamful per rad than alpha radiation, can also cause cancers, teratogenesis, and genetic damage. Our nealth risk estimates are baseci on our review of epidemiological studies conouvted in tho United States and other countries of underground miners of uranium and other metals who have been exposed to radon decay products, and on two reports, "The Effects on Population of rixnnsure to Low Levels of lonizing Radiation" (1972) and "Health Fffects of Aluha Enitting pariicles in the Respinatory Tyact" (1970) by the Advisory Connaitte an itri Bislogicai Efrects of Ionizing raviation of the: National Academy of Sciences (the BEIR Cornmittee). Informaticin in tice repori of

\footnotetext{
'A working level ( $W L$ ) is any combination of short-lived radon decoy producis in ore liler of air that will result ia tioc ultimete onission of piuta

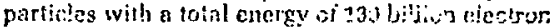
volts. The working level expesscsi a crirt:-aitiotion of redioactivily in the air, Jot knw Inuch rodiation a

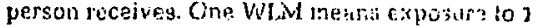
WL for 170 hovis, he number of wotkine luess in a morth, based on a 10 -hour workiug w:sek

${ }^{2} A$ sad neaseures the energy atsorbid fing uai

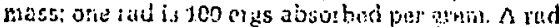
is more fondamertuly related to biologra: danage than e WIM. but it is convenient to state iat?on deray product exposure in Whit's becastse siost of the deta on their health elfects comes foor sindies of uranium miners and is thated it: WLW's. However, raners bredthe more as they work thas

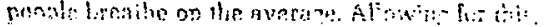

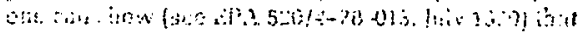

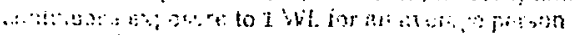
curiesponis to 27 WIMU in a year. One blist is rouginly equivalent to 0.5 rad tu tie jumg.
} 
- United Nations Scientific Committee

the Efiects of Atomic Radiation entitled "Sources and Effects of Ionizing Radiation" (1977) was also considered. Details of our risk estimates are provided in "Indoor Radiation Exposure Due to Radium-22.6 in Florida Phosphate Lends" (EPA 520/4-78-013) and in the Draft Environmental Impact Siatement (EIS).

Data frem studies of underground miners lead to uncertain risk estimatos when extrapolated to the general population. Nevertheless, we believe they provide a sufficient basis for public health standards. Data from many exposed groups are available as a basis for gamina rny exposure standards. Sumntarics of our risk estimates (using both the "relative" and "absolute" risk models) fur exposure to radon decay products and to gamma radiation ere given in Table 1. The assumptiong of these models and the applicability and basis for the estimates ere discussed in the EIS.

Generally it is not possible to remove all the risk to people exposed to radiation or any cher dangerous substance. To help us decice how much we should attempt to reduce the risk, we considered the longevity, efficauj, aliu voiv vï inneaiai action diteinocis ior. ulaniurir mill tailings as well as the level of risk. We also considered benefits and costs which are not easily quantified, such as rquity, and admisistrative difficulties. Finally, we considered the overall implementation costs and benefits of alternitive standiards ta deterinine those which are most réisonable.

EPA's manciate is to set standards which apply to any site and method of control. The law gives other agencies of Government the authority to decide how these stantards will be satisfied at particular losations. Thcrefore, our analyses of tochnolugy, cos?s, risk, and other pertiuent factors emphasize the generai charactcristics of uanium mill tailings alid their conirol.

The infonination, reasoning, and judgnents which lead us ta issue these particular propcesd cicanup siandards for inective tranitm processing sites are summarizad below. Additioial beckgrounci information is contained in the Draft Envirenmental Impact Statement which is on file in the Uocket ...'d will be available for distribution wtly.
Table 1(A).-Estimated Risk of Fatal Lung Cencer Due to Radon Docaj Products' ' (for 0.01 Working Level and Lifetime Exposure 75 percent of the Time?

\begin{tabular}{|c|c|c|}
\hline & \multicolumn{2}{|c|}{ Estimated risti } \\
\hline . & Rolative & Absolute \\
\hline $\begin{array}{l}\text { Percent of the exposed who will die } \\
\text { of lung cancer caussed by the } \\
\text { exposife ' } \\
\text { Years of tile losi par latality? }\end{array}$ & $\begin{array}{r}1 \\
15\end{array}$ & ${ }_{25}^{0.5}$ \\
\hline
\end{tabular}

Table 1(8).-Estiriated Fisk of Fatal Cancer Due to Exposure of the Whola Body to Gamma Radiation ' (for Lifetime Expusure at 100 mrad per Year)

\begin{tabular}{|c|c|c|}
\hline & \multicolumn{2}{|c|}{ Estimated risk } \\
\hline & Relative & Absolute \\
\hline 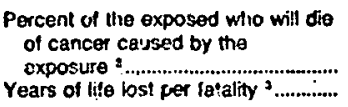 & $\begin{array}{c}0.5 \\
14\end{array}$ & $23^{0.8}$ \\
\hline
\end{tabular}

'Estimated lifetime risk of tatal cancer caused by tho ind cated role of radiation exposure over an aveisje lifetims (70.7 years).

'The peicentage for higher or lowyer raciation levels changes in proportion, except for very high love's. Exposure over less tha. 70.7 yaars gives smaller risks; howover, the expectod effect of an exposure depends on the recipient's sge at the time, so the risk is not strictly proportional to the exposure time.

"Another miessure of harm is "everage days of life los! per exposed person." This is gotion by multiplying the hwo num. exfosed person." This is gorten by miltiplying the hwo num. bers in each vertical column. For exampla, the estimated P.el-
ative Risk in Part A of the Table is $(0.01) G 3 \times 15$ yoars $=5.5$ aisiage days ol like losi pei exposed persón

ii. Cieariup of Upon Lands and Buidings s

Uranimum mill tailings from inactive sites have been spread by wind. water. and people to nearby and distant locations. Therefore, standards for cleanup of tailings must address the following situations:

(1) Tailings have spread different distances from different piles, occur at

'Under Tit!e i of Foti. L. 95-got, ihe Departmant of Energy nia y desiunstc as a "processing site" cligib!e fo: rtmeriial actions:

"(A) any gite, ine?ut!ing the mill, containing residual ridioactive materials al which all or substantislly cll of the uranium was produced for sale to any Federal agnocy - - -

(D) any other real property or improvement thereon which-

(i) is in the vicinity of such site. and

(ii) is deternired by the Secretary. in cunsultation

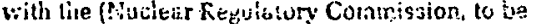
contaminared with teyid!nal radioactive insterials derived from cuch gite."

Therelore, remedial actions may be netdat for the tuilings or other rcsiddal rabiciacive nits rials stored at en inactive mill. an tyell os for builcings or lands, on or off the ciriginil mill site, which are alfected by radiciactive matcriall de:ived from the mil!. The linrd portion of a "dssiznisted precessing site," i.e., all but the builjinga, may co:ssist of two parts: The disposel site, if the tailingy are to be permanently lept of the cite, ond the remeining land. We will uso tle tean "open lanj" goi any land (surface ard bubsuface) which is not a disposal sito

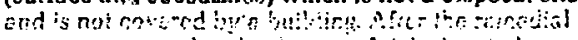

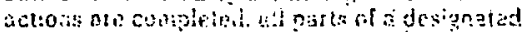

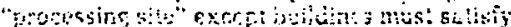
either the stardards for disposul or the standirds ior open lunds. various depths in the soil, and are mixed with various materials. The standard must specify the quantity or concentration of tailings which requires cleanup.

(2) Radionuclides leak into the soil under the piles, If these piles are removed, the maximum allowable residual level of radioactivity in the subsoil must be specified.

(3) Tailings that have been used as landfill or in building materials, or have accumulated around a structure are particularly hazardous. Building interiors have limited oirflow and radon decay product concentrations in them may be many times the outdoor levels. Thus, the standard must specify the maximum allowable radun decay product concentration in buildings. The cleanup standard for open land must consider the possibility of future building on the lard.

Before Pub. L. ST-fOA was enacted. EPA and the predecessors of DOE (the Atomic Energy Conmission and the Energy Research and Development Administration) conducted surveys to identify places where tailings from inective processing sites had been used in construction, and to determine the extent of contamination of open lands. Since then, additional measuivements have been mado by fureral, State. and local authorities, and are continuing 8 part of the program authorized by Title I of Pub. L. 95-604.

\section{Proposed Cleanup Siandards for Open Lands.}

The greatest hazard from taiings on open lands is increased levels of radon decay pruducts in buildings. Exposure to direct gamma radiction and conianination of driatilug vater ant food nuy a!so ocrus, but seterally wil ba of iess concern.

The radon decay froduct concentration in on existing or future building will depend on the raciurn concentration in tha soil under or adjacent to it. However, so mary other factors affect the indror racion decay product oncentration thet a useful corrstion with the radiust in soil is difficult to establish. Lisider come condtiors, radium concentratione ss low as 1-5 pCi/grn in naturat or contaninated soil can predtce irdoor raduil decay product criscentration exceeouing 0.01 IVL. Comnion natural soiis have radium concentrations near tha lswer end of this range. Thersfore, wisere indoor radon decay produc! concentrations are only slighlly

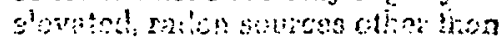

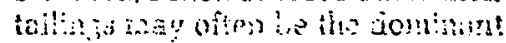
causes, and removing the tailings may do little good. 
1 Naturai or contaminated soils which have $5 \mathrm{pCi}$ of radiun per. gram of soil for Eeveral feet down can also give exposure rates from gamma radiation of about $80 \mathrm{mR} / \mathrm{yr}$. The exposure rates are proportional to the concentration of radium, and decrease as the layer of radium-containing material becomes thinner, or is covered over by other materials. Therefore, clearup standards for open land must take account of both the level of radium concentration and the thickness of the contaminated layer.

Locating contaminated soils with concentrations less than $5 \mathrm{pCi} / \mathrm{gm}$ would require extensive surveys and lengthy measurement procedures. Increasingly large land areas would nead to be stripricd hin orier to lowar the radioactivity much below $5 \mathrm{pCi} / \mathrm{gm}$. Doing this vrould provide very little gain in health protection, since such slightly cortanirnated soils are usually thin layers containing little tọtal radium. Therefore, in order to keep sampling costs within reason, and to avoid having to clean large areas which contain little radioactivity, the proposed standard requires that for any open land contaminated with fallings, the average radium concentration shall not be more than $5 \mathrm{pCi} / \mathrm{gm}$ after cleanup. The contamination which remains after such cleanun will have less than 5 times the radon wrasso of fwromen snila it conld also cause a gamma radiation dose of less than 80 millirad per year to a person who spends 100 percent of the tine. nutdoor's on the site. These levels c: radon emission and ganma radiation are within the variations that occur in undisturbed land areas. We believe that the actual radon and gamma ray levels after cleanup wili usually be rnuch less than the maximum possible under these standards,

For contaminated material located more than I foot beneath the suriface of open land, our propused standard requires clranurs if the average radium concentration over any $15 \mathrm{~cm}$ thickness is greater than 5 y.h/gnt. Practical measurement instruments could not find buried material of this cencentration in any thinner layer. We expect this standard for buried maierial will mostly apply to dofiring the exlges of buried tailings deposits, bevisuse the rodium concentration in tailiriss is usually much higher than $5 \mathrm{pCi} / \mathrm{gm}$.

Surveys at hactive jrocessing siles incizate that it should cost little more to impierrent the proposed cleanup standard than one pernitling lesidual

\footnotetext{
The roentgen ( $R$ ) is a urit nieasuing the

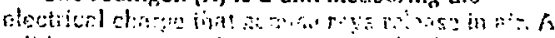

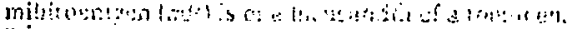

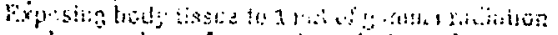
producc a doec of approvimalu! 1 mrad.
}

contamination levels 2 to 4 times higher. The proposed cleanup standard is EPA's judgment of the most string'snt uniform cleanup condition that may reasonably be required for all the inactive mill sites.

We expect that the rules developed to implement this standard will relate the concentration of radium in soil to other conveniently measured quantities. We also expect that appropriate sampling techniques will be establiched to locato and identify tailings material, to determine its concentration of radium, and to verify compliance with the standard. Any such rules must insure that the standard is rot met by dispersing the material to achieve a lower concenuation.

\section{Proposed Cleanup Standards for Indoor} Radon Decay Product Concentration

Even normal levels of indoor radon decay produci concentrations are harmfu!. We believe that Congress intended that people should not have to bear an unreasonable increase in this risk because of tailings.

A standard should have the following characteristics:

1. Unambiguous. It should be clear whether or not a situation meeis the standard.

2. Risk-related. It should limit the harm done to people.

A. ront-rolated The cort should bo related to the amount of injury prevented.

4. Practical. It must be possible to accomplish the requirements in 2 reasonable time with the techniques and personnel available.

We consldered expressing the cleanup standard for indoor radon decay products in terms of the

1. Quanlity or concentration of tailings near the building;

2. Gamma radlatlon lsvel lit the building;

3. Amount by which the indcor racion decay produsi concentration exceeds the level is rould be if no tailings were present in or near the building;

4. Amount by which the indoor radon decay produnt concentration exceeds what the average level in similar. buildings in the areas rould be if there were no tailinga in the region;

5. Rarion decay product conceniration is the bijidir!g.

Alterratives 1 and 2 aic not strongly: risk-related or cost-reiäisd irecause there is no known way to diecuce the irdoor racion clecay product

concentration from them.

Alicrmative 3 is impracical because there is no known vay to determine

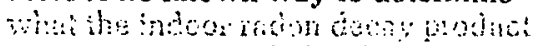

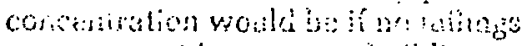
vere prescrel is or neas a building except by removing all the tailings. Thus, under this alternative, one would have to perform the remedial action in order to determine if the building was eligible for remedial action.

Alternative 4 is impractical and ambiguous because it wil! be too difficult to estatulisi which builuings that are inot affected by tailings are "similar" to a given building that is affected. This is because indoor raden concentralions vary significantly with building location, design, materials, and patterns of use. The reasons for these variations are not well understood.

Alternative 5 is unambiguous. practical, cost-related, and directly related to the total risk to people living In the building. W'c have thuo nhoson to base our standard on it.

We believe that the proposed remedicl action leval of $0.015 \mathrm{WL}$ (imclucling background) for ascupied or occiupiable buildings is the most protective level that zan ue justified for the Pub. L. 95-604 remedial action program. It is about the same es that applied to homes and schools cver the last seven years in the Crand Junction. remedial action protgram, becatise the action level there was 0.01 WL obove an "everage" backround value taken as 0.007 WL. Experience in tine Granc Juncliun program indicates that it is usualiy ieciniscaliy and tinancially practical to lower concentrations greater than 0.017 WL when the high working levels are due to ressidual radioactive materials from uranium processing sites. 0.017 WL is practically indistinguishable from our level of $0.015 \mathrm{WL}$. In sone situations, a lowsr action level mignt be justified. However, since studies of normal houses with basements in Giand Junction. Nerw Yorl: Stale, and Sew Jersey inrlicale tiat a jecet 10 jercent are above $0.015 \mathrm{irl}$, it wonld ofien ba fruilless to try lo redice levels significartly belcw 0.615 Wh, it would ofien be fruitless to try lu reduce lavels significantly below $0.015 \mathrm{v} / \mathrm{L}$ by removing tailings.

Although incioor radon decey product levels much higher then $0.5 \mathrm{~s}$ WL oan occur withovt the presence di veaturn raill tailings, these proposs dearip standarde ore explicit!y for remeciat? actions at sites designated arice cub. $\mathcal{L}$. $9,-60.5$ Fub. $1 ., 95-604$ is rlearly directed at poiential health probleras cue to tailings, and not to similar hazands frrom other causes. The proposej cleastum niandard thonforo arplitas only when there is reason to believe that the

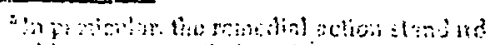

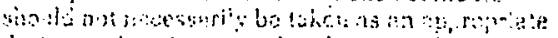

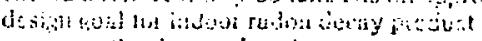
comentration in neiv tousting.
} 
"lowable level is exceeded because of anium mill tailings from a designiated orie. If the allowable level is still exceeded after all apparent tailings have been removed or otherwise prevented from affecting the interior of the building, then the standard does not require further remedial measures.

\section{Proposed Cleanup Standards for Indoor} Gamma Radiotion

The proposed standard for indoor radon decay product concentration is based on the hazard from breathing air containing these products. Tailings also emit gamma radiation, however, which can penetrate the body from the outside. We expect the indoor radon decay product concentration standards will usually be met by removing tailings from the building, and that this will eliminate any indoor gamma radiation problem. For some buildings, however. engineering problems may make it impractical to lower the indoor radon decay product concentration by completely removing tailings. Alternate methods, such as air cleaning, improving ventilation, or applying sealants to the walls and floors are available. If these are used; standards will be needed to limit gamma radiation exposure of the occupants.

It will often be possible to mect the

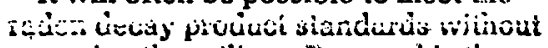
rinoving the tailings. Nemoval is the remedial method we wish to encourage. however, because it is a permanent solution. To do this we have chosen a proposed action level for gamma radiation $(0.02 \mathrm{mR} / \mathrm{hr}$ above background) 6 which will be hard to mect without removing tailings when these are the cause. On the other hand, reducing the standard much below 0.02 $\mathrm{mR} / \mathrm{hr}$ would virtually eliminate flexibility in remedial methods, and provide only a smull additional health benefit to those few individuals who might be affected. Assuming the occupants of the building to be in it 75 percent of the time, the proposed cleanup standard would allow gamma radiation doses from the iailings of about 130 mrad par year. This is about twice the everage anaual outdoor background dose from gamma rays in the westeris United States.

\section{Proposed Cleanup Standara for}

Radiation Hazards Not Associated With Radiun-226

Each gran of natural uranium contains $\$ 30,000$ pCi of U-236 and 15,000 $\mathrm{pCi}$ of $\mathrm{U}-235$. Because it appears in

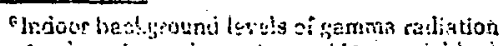

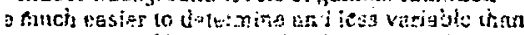
:usurements of hijekground siciocr radon decay - oduct concentration.
}

relatively small proportion, uranium-235 and its decay products usually may be ignored in evaluating the hazards of uranium tailings. The dominant hazard from most tailings is the decay products of uranium-238, especially radium-226 and its decay products. This is the reason the proposed cleanup standards specify a limit on the radium-226.

The amount of protection provided by a standard based on radium-228 depends on the extent to which radium has been separated from other radioactive substances, such os thorium, uranium-235, and their decay products, during ore processing. The Department of Energy has determined, for example, that at lesst one of the processing sites covered under PL 95-604 (Canonsburg. $\mathrm{Pa}$.) has tailings containing higher than usual proportions of uranium-235 decay prodicts. Radium-220 concentrations in the residual material may not be an adequate measure of the radiation hazerd in this case.

The environmental pathways and biological effects of some of the thorium and uranium-235 decay products are not as well known as for radium-226. Thus, we are not in a position to set a separate standard for them, nor to say in all cases how effective cleanup standards based on radium-22.6 will be controllíng ironis-235, 4h-zinim, and their decay products. However, adequate protection would be provided if, after cleanup, the total risk from all uranium and thorium isotopes and their decay products posed no greater risk than the proposed cleanup standards allow fór radium-226 and its decay products. The degree to which any particular site would need to be cleaned up in order to meet this condition will have to be determined following detailed studies of its tailings, and further evaluation of the hazard pathways.

\section{Implementation}

Pub. L. 95-604 requires that EPA's standards for uranium mill tailings from inactive processing sites be implemented by the Secretary of Fnergy. The Secretary or a designee will seleci and perform remedial actions for designated processing sites in accordance with the standards, with the full perticipation of any State which shares the cost. Selection and performance of the remedial actions will be with the concurrence of the Nuclear Regulatory Commission and in consultation, as appropriate, with affected Indian tribes and the Secretary of the Interior. The costs of the remedial actions will be borne by the Federal Goverument and the States as prescribed by law.
The Department of Energy will need to make a radiation survey of open lands and buildings in aress believed to have tailings and determine whether or not tailings are causing the standards to be exceeded. After remedial actions are taken, they must verify compliance with the standards. In order to do this, DOE, working with NRC and the participating State, will need to develop radiological survey, sampling, and measurement . procedures to determine necessary and practical cleanup actions, and to certify the results of the cleanup.

These procedures are an important part of making the standards effective. In view of this, we considered providing more details of the implementation as part of our rulemaking. We chose not to do so in order to give more flexibility to the implementers. We believe this is warranted because of widely varying and incompletely known corditions among and within the various" processing sites. However, the following clarification of our intentions should help to avoid unproductive use of resources. This could result if the standards were interpreted so strictly that demonstrating compliance would be unreasonably burdensome.

The purpose of our standards is to protert public health and the environment. We designed them to be adequately protective using search and verification procedures whose cost and technical requi! ments are reasonable. For example, since we intend the cleanup standards for buildings to protect people, measuremients in such locations as crawl spaces and furnace: rooms are inappropriate. Remedial . action decisions should be based on radiation levels in the parts of buildings where people spend substantial amounts of time. The standards for cleanup of land surfaces are designed to limit the exposures of people to gamma radiation, and to limit the level of radon decey products in buildings which might later be built on the land. In most circumstances, no significant harm would be caused by not cleaning up a few square feet of open land conlaminaled by tailings. Similariy, it would be unreasonable to require proof that all the tailings had been found below the surface of open lands. As in all applications of our proposed cleanup standards, ssarch and verfication procedures which provide a reasonable assurance of compliance with the standards will be adequate. We are confident that DOE and NRC, in consultation with I:PA and the States. will adopt implementation procedures consistent with our standards. 


\section{Exceptions}

We believe that cur proposed standards are the strictest that are justified for general application at all the inactive uranium processing sites covered by Pub. L. 95-604. However, providing grealer protection may be reasonable at specific sites. Therefore, we urge the inplementers to lower the rcsidual risk as far below the required levcl as is reasonably achievable.

In the decades since tailings at inactive sites were deposited, weatrer and people have created a wide range of problens needing remediation. There may be exceptional circumstences for which the standards are unrcasonably strict, such as when some clearly undesirable health or environmental side-effects would be caused by meeting them. For example. when tailings are not accessible to the cquipment needed for their removal; or where workers might be endangered in trying to remove them, application of the standards should be reconsidered. Similarly, disturbing scárce desert vegetation and soils may not bo justified where the standards are only sligitly exceeded.

We do not consider cost a reason for noncompliance unless the cost to comply is verv high or the benefit is very snail. for examplc, it may not make sense to spend a great deal of money to clean up an infrequently occupied buildine where the standards are only slighliy exceedsd.

In order to allow for reasonable implementation of Pub. L. 95-504 in all of the varied circunstances, we are proposing criteria which the implementers may use to determine Whether particislaz ci:cumstances are exccptionai. In sicil exceptional cases, DOE may select and perfom remediai actions which come as close to meeting the standards as is reasconable. In the selection of such remedial actions, $D O E$ shall ask any property owners and occupants for their comments, the concurrence of NhC shali be reguired, and DOE siall irioim ISPA.

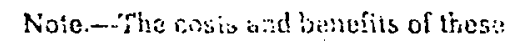
standaids are dieclesed in the Diatt Envircnmental Inipart Statement. However, neiticer our issnance of juterlm cleanup standards nor the remaiuder of our program to set remedia! action staritards for $\Gamma$ ib. $L$. 95-604 require prejaralien of an economic

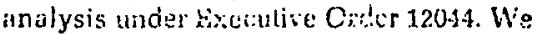
finject the cosis of the remedial action program iri any: calendar year to be less than

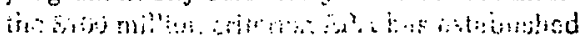

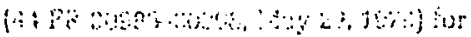
requiring an cconomic anaiygis.

Dated: April 14، 1980.

Douglas M. Costle,

Administrator.

The Administrator of the Environmental Protection Agéncy hereby proposes to add a Part 192 to Title $4 n$ of the Code of Federal Regulations as follows:

\section{PART 192-LEVVIAONHESTTAL. FPOTECTION STANDATIDS FUR UPAHIISA MILL TAILIHGS}

- Subpart A-[Eeserved]

Subpart ty-menvironmental Standaris for Cleanup of Open Lands and Euiloings Contominatod with Reridulual Harlinartlve Habterials from Inactive Urarium Processing Sitos

Sec.

192.10 Applicability.

192.11. Definitions.

192.12 Stindards

192.13 Effective date.

\section{Subpart $c-$ Exceptions}

192.20 Criteria for exceptions.

192.21 Rernedial actions for exceptional circumstances.

Table A-[Reserved]

Table $B$

(Authority. Section 275 of the Alomic Energy Act of 1954, (42 U.S.C. 2J22), as amended by the Liranium Mi!l Toilinzs

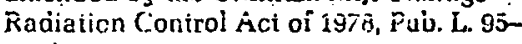
Cï-i.j

\section{Subpart A-[Reserved]}

Sutpart 2-- Ervironmental Starctards for Cleanup of Open Lands and Bulldings Conisminated with Residual Radioaclive Ahaterials from Inactive Uranium Processing Sites:

§192.10 Applicability.

This subpart applies to open lands and bildiugy which are part of any processing site desigrated by the Secrelary of Energy uncer Pub. L. 95604, Secticin 102. Section 101 of Puh. L. 95-604, states that "proce;sing sits" means--

(a) Any site, including the mill, containing residual radioactive materials at which all or sajglantially all of the uranicm was produced for sale to any rederal ugenoy fojor to fermary 1. 1571 uncler a conthact with anj Federal agency, except in the case of a site at or near Siick Kock, Coiorado, unless-m.

(1) Such site was owned or controlled as of January 1. 19\%8, or is thereafter owned or controlied, by any Fedeial agency, or

(2) $A$ license !issued by the (Nuclear Regulatny) Commission or its

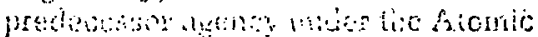

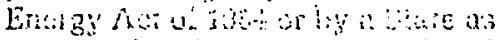
permitted under section $27 s_{\text {of }}$ such $A c t$ ) for the produclion at such site of any uranium or thorium product derived from ores is in effect on January 1, 19;, or is issued or renewed after such date; and

(b) Any other real property or improvement thereon which-

(1) Is in the vicinity of such site, and

(2) Is determined by the Secretary, in consultation with the Commission, to be contarninaied with residual radioactive materials derived from such sile.

Any ownership or control of an area by a Feteral agency which is acquired pursuant to a cooperative under.this title shall not be treated as ownership or cunluul by suich agency for purposos of paraglaph $(\bar{a})(1)$ of this section. $A$ license for llee pis soluction of any uranium product from residual radiuactive materials shall not be treated as a license for produc!ion from ores within the micaning of paragraph (a)(2.) nf this section if such production is in accordance with section 108(b):

§ 192.11 Deflnitions.

(a) Unless otherwise indicated in this subpart, all terms shall have the same - meaning as defined in Title I of the Uranium Mill 'Tailings Radiation Control Act of 1978.

(b) Remedial action means action performed under Section 108 of the Uranium Mill Tailings Radiation Control Act of 1978.

(c) Open land incans any surface or subsurface land which is not a disposal site and is not covered by a building.

(d) Working Level ( $/ \mathrm{L}$ ) means any combination of short-lived radon decay products in one liter of air that will result in the ultimate enission of alpha particies with $:$ total energy oi 130 billin electror volts.

(e) loso equivalont nocans absorbed doss mullichiec by uppropilate factors to account for differences in biologica! effectiveness due to the type and energy of the radiation and oilicr factors. The unit of dose equivalont is the "rem."

(I) Curie (Ci) niears the amount of radionctive material which produces 37 billion nuclear translormations per secord. One picocuris: $(p \mathrm{Ci})=\mathrm{i0}^{-12} \mathrm{Ci}$.

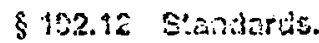

Remedial actions shall be conducted so as to provide reasonable assurance that-

(a) the areicige concentration of racium-2as attributabic io residual radioactive material from ary designated processing site in any $5 \mathrm{~cm}$ thickness of soils or other materials or. open lajed within 1 foot of the surfare. ju any ? 5 on : theses below I ioot, shall nut excedci o j $\mathrm{Ci} / \mathrm{s}$.

(b) The lavels of radioactivity in any occipied or sociajiable builuing shall 
not exceed either of the values specified in Table $B$ because of residual rodioactive materials from any designated processing site.

(c) The cumulative lifetime radiation dose equivalent to any organ of the body of a maximally exposed individual resulting from the presence of residual. radioactive materials or byproduct materials shall nol exceed the maximum dose equivalent which could occur from radium-22.0 and its decay products under paragrapts (a) and (b) of this section.

\section{\$192.13 Efiectlvo date.}

'The standards of ths subpart shall be effective 60 days after promulgation of this rule.

\section{Subpart C-Exceptions}

$\$ 192.20$. Criterla for exceptions.

Exceptions to the standards may be justifiable under any of the following circumstances:

(a) Public health or safety would bc unavoidably endangered in attempting to meet one or more of the requirements of Subpart $A$ or Subpart B of this part.

(b) The goal of environmental protection would be belter served by not satisfying cleanup requirements for open land, $\$ 192.12(\mathrm{a})$ or the corresponding part of $\$ 192.12(\mathrm{c})$. To justify an excoption to these requirentils inere ond is u cicuriy arfavolable inbalance totwetin the environmental harm and the environmental and health benefits which would result from implementing the standard. The likelihood and extent of current and. future humañ presence at the site n:ay be considered in evaluating these benefits.

(c) 'Thre estimated costs of remedial actions to comply with the cleanup renuirements for buildings, $\$ 192.12(b)$ or the corresponding piti of $\$ 192.12(c)$, ere unreasonably high relative to the benefits. Faciors which rnay be considered in this judement include the perios of occupuncy, the radiation levels in the most frequentiy occupied areas, and the residial useful lifetime of the buiiuing. This criterion can only be used when the values in 'table $\mathrm{B}$ are oaly slightly sacceedrod

(d) Thare is ricknown remedial action to meei one or more of the requiraments of Subjort \& or Subpart B of this part. Destuction and condemination of buildings are not consiclered remedial actions for this purpose.

\$ 132.24 Femmedial sctions for exceptlonal ircuriaiances.

Section 108 of Pub. L. 95-ons requires

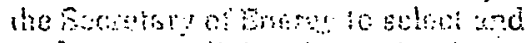

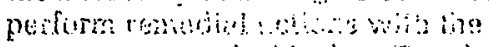
concurrence of the indear Regulatory
Commission end the full participation of any Stale which pays part of the cost. and in consultation, as appropriate, with affected Indian tribes and the Secretary of the Interior. Under exceptional circumstarces satisfying onc or more of the conditions 192.20(a), (b). (c), and (d), the Department of Energy may select and perform remedial actions, according to the procedures of Sec. 108, which come as close to meeting the standard to which the exception applies as is reasonable under the exceptional clrcumstances. In doing so, the Department of Energy shall inform any private owners and occupants of affected properties and request their coriments on the selected remedial. actions. The Department of Energy shall provide any such comments to the parties involved in inplementing Sec. 108 of Pub. I. 95-601. The Department of . Energy shall also inform the Enviromantal Protection Agency of remedial actions for exceptional circlimstances under subpart $C$ of this rule.

\section{Table A-[Reservad]}

\section{Table $\mathbf{A}$}

Averages Annual Indoor Hadon Decay Prnduct Con contration-inc:luding background $W L$ )..................
Indoor Gamrna Radiation-8bove background (millis

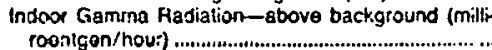
0.015 [FR Doc. 80-12309 filed 4-21-60: 8:45 cm] BILLING CODE 6560-01-M 
APPENDIX C

SUMMARY OF EPA INTERIM AND PROPOSED STANDARDS 


\section{APPENDIX D}

REPROCESSING ACTIVITIES INVOLVING INACTIVE

URANIUM MILL TAILINGS PILES, FEDERAL REGISTER NOTICE 
fteen days after publication of the riginal notice in the Federal Register.

Dated: May 29, 1980.

Frederick. McGoldrick,

Acting virectör for Nuclear Affairs. International Programs.

[FR Dö. Ba-1cGsi Filed 5-20-80: 11:00 am|

BILUMG CODE 8450-01-M

Uranium Mill Tailings Remedial Actions Project Office, Albuquerque Operations Offlce; Solicitation of Expressions of Interest to Reprocess Uranium Mill Taillings

AGENCY: U.S. Department of Energy. Uranium Mill Tailings Remedial Actions Project Office, Albuquerque Operations Office.

ACTION: Program Information Notice: Request for Expressions of Interest in Remilling Pursuant to Pub. L. 95-604.

SUnsmary: The Uranium Mill Tailings Remedial Actions Project Office (UMTRA-PO) of the Albuquerque Operations Office (ALO) of the Department of Energy (DOE) is. requesting expressions of inlerest from qualified, private parties regarding the remilling of the residual radioactive materials at the inactive uranium mill tailings sites designated pursuant to Pub. L. 95-604, the "Uraniun Mill Tailings Radiation Control Act of 1978." This request for expressions of interest will implement the authority of DOE derived from section 108(b) of Pub. $L$. 95-GO4 to determine interest in remilling the urauium mill tailings.

EFFECTIVE DATE: July 14, 1980.

FOR FURTHER INFORMATIOM CONTACT:

(1) Mr. Richard 11. Carnpbell, Project

Minajer, Uranium Mill Tailings

Remedial Actions Project Office, U.S.

Department of Energy; P.O. Box 5400.

Albuquerque. New Mexicn 87115.

Telephune (505) 844-3941, or

(2) Mr. Mark I. Matthews, Project Engineer, Uranium Mill Tailings

Remedial Actions Project Oifice, U.S.

Department of Energy, Albuquerque.

New Mexico 87115. Telephone (505)

844-2185.

\section{SUPPLEMENTAAY INFOKHATION:}

The "Uruniumi Mifll Tailirgs Radiation Control Act of 1978," Pub. L. 95-604, authorizes the Depaftment of Finergy (DOE) to underlake a program of remedial ạction at designated inactive urunium mill tailings processing siles and vicinily properties. The program is aing undertaken in order to stabilize id control the tailings in a safe and environmentally sound manner and to minimize or eliminate radiation health hazards to the public. Remedial actions undertaken pursuant to the Act are to be accomplished in cooperation with the. interested Stales. Indian tribes, and the persuns who own or control the mill tailings sites. Rémèdial actións àre to' include, where appropriate and practical. the icmilling of tailings to extract residual uranium and other mineral values.

Pursuant to section 1n8b of the Act. prior to undertaking any remedial action at a designated site. the Secretary is directed to request expressions of interest from private parties regarding the remilling of the residual radioactive materials at the site and, upon receipt of any expression of interest, the Secretary must cvaluate the mineral concentration of the residual radioactive materials at each designated sito to determine whether, as a part of any remedial action program, recovery of such minerals is practicable. The Secretary may, with the concurrence of the Nuclear Regulatory Commission, permit the recovery of such minerals under. such terms and conditions as he may prescribe. Section 101(7) of the Act defines "residual radioactive materials" as "(1) waste (which the Secretary of Energy determines to be radioactive) in the form of tailings resulting from the processing of ores for the extraction of uranium and other valuable constituents of the ores; and (2) other waste (which the Secretary determines to be radioactive) at a processing site which relate to such processing, including any residual stock of unprocessed ore or low-grade materials." Section 101(8) of the Act defines "tailings" as "the remaining portion of a metal-bearing ore after some or all of such metal, such as uranium, has been extracted." No recovery is permitted unless the recovery is consistent with remedial action. Any person permitted by the Secretary to recover such mineral must pay to the Secretary a share of the net profils derived from the recovery as determined by the Secretary. After payment of such share to the Linited States. the person shall pay to the State in which the residual radioactive meterials are localted a share oi the net profits derived frum the recovery as determined by the Secretary. The person recovering the minerals bears all costs of such recovery. Any person carrying out mintrial recovery activities under this program is regunired to obtain a license under the Atomic Eneray Act of 1954 or under Stute laiv as permitted under section 274 of the Act.

the Uranium Mill Tailings Remedial Actions Project Office (UMTRA-PO) of the $A$ lbuquerque Operations Office (ALO) of the Department of Energy is presently requesting expressions of interest from quialified; private parties regarding the remilling of the residual radioactive malerials at the inactive uranium mill tailings sites designated pursuant to Pub. Lo 95-604.

The Incations and curtent owners of those inactive uranium mill tailings sites. upon which remilling may be permitted under Pub. L. 95-604 are as follows:

Sité, location, and owner

1. Cannonsburg. Pennsylvania. Canon Development Company (V. Crile).

2. Salt Lake City, Utah, Salt Lake County Suburban Sanitary District.

3. Durango, Colorado; Ranchers Exploration and Development Corporation $(\boldsymbol{H}$. Campbell).

4. Grand Junction, Colorado, Shumway Drilling Company (R. Shumway), AMAX. Inc.

5. Riverton, Wyeming. Lome Drilling \& Well Servica. Inc. (11. S. Harnsberger: Jr.).

6. Gunnison, Colorado. Decker, Bishop \& McEachem (N. M. Bishop).

7. Rifle (Old). Colorado. Union Carbide Corp. (R. Beverly).

8. Rifle (New). Colorado. Union Carbide Corp. (R. Beverly).

9. Lakeview Oregon, Precision Pine Co. (N. Stock).

10. Ambrosia Lake, New Mexico. United Nuclear Corp. (H. J. Abiss)

11. Green River, Utah, Union Carbide Corp. (R. Beverly)

12. Slick Rock (North Continent), Colorado. Union.Carbide Corp. (R. Beverly)

13. Slick Rock (Union Carbide), Colorado; Union Carbide Corp. (R. Beverly)

14. Maybell, Colorado, Union Carbide Corp. (R. Beverly)

15. Converse County (Spook), Wyoming. Western Nuclcar (G. Bogden)

16. Monument Valley, Arizona, Navajo Tribe (P. MacDonald)

17. Tube City, Arizoni, Navajo Tribe (P. MaciJonald)

18. Shiprock, New Mexico, Navajo Tribe (P. MacDonald

19. Mexican Ilat, Utah, Navajo Tribe (P. MacDonaid)

20. Fa!ls City, Texas, Solution Engineering Co. (T. Fife), Lyssey Dairy Farms (V. Lissey), S. Niestroj

21. Lowman, Idaho, Velsicol Chemicsl Corp. (W. Giblin)

22. Belfield, North Dakota, Burlington Northern Railway

23. Howmun, North Dakota, Chicago Minneapolis St: Paul and Pacific R ralroad

24. Bagys. Wyoming. Information not available

Expressions of interest for tailings remilling are requested at this time. After review of these expressions of interest. DOF may at some time in the future solicit remilling proposals from those who have expressed interest.

Partieg intercstedia oblaining specific information regarding the mill tailings are advised to conlact either the owner directly or the following person: Richard H. Campbell, Project Manajger; Uranium 
Mill Tailings Remedial Actions Project Office, U.S. Department of Energy,

Albucucrque Operations Of́tice.

Quilified firms intending to express interes: should submit, within 45 days from ?ublication of this an:curas:meall. an tapression of inlerost inciantag a brief statement of their cariabiaity to cond:al remilling operativils and any other restinimt data, not to exceed a total of three single-spaced lypewritten pages.

Resronses should be addressed to: Richard Hi. Campbell. Project Mantiger.

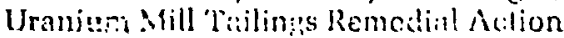
Proicai Olliçe, U.S. Lenartment of Eners: Albuqquerquc Uprialtans Ufflec. P.O. B.x 5täj, Albuguerųue, New Muxico E711:.

Issuges in Washingtom. D.C. Migy a. inoo. folun ?:?. Sisisfordi,

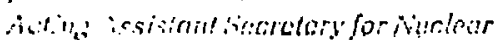
Enterigy.

[FR Dor. PO 16045 riled 5-21\}-80; 8:45 am] BILLIHE CODE 6450-01-M

\section{Eouttieastern Power Administration}

Cumberined Basin Prolecto; Order Ezitendivis Corfirmation and A!sproval of Pow': frates on an Interin Easis

ACENCY: Uepartment of Energy, Suis!heastern Power Administration (SEY'A).

S.CTION: Extension of approval on interim basis of Cumberland Basin 'rojects' rates.

\section{SUAMaAy: The Federal Energy}

kegulaicry Commission (FERC) has not laken action on the rate schedules for Cumber! and Basin power approved, on an interim basis, by the Assistaut Secretary for Resource Applications and submilted to FERC on May 22, 1979. Since action by FERC is not expected prior to June 30,1980, when the interirn approval expires, the Assistant Secretary has extended the effective period for the applicable rate schedules as provided in Rate Order No. SEYA-8. Ei . ECTIVE DATES: Extension of confirmation and approval of rates on an interim basis effective July 1, 1980. FOR FURTHER INFORMATION CONTACT: Sidney M. Cleveland, Acting Chief, Division of Fiscal Operations,

Southeastern Power Administration.

Department of Energy. Samuel Elbert

Buildinn. Ellberton, Georgia 30635 (404) 223-32.61.

trimes A. Blaxdale, Officc of Power Markrting Coordination, Wejartment of Energy, 12th Street and Pennsylvania Avenue, N.W.. Washington, D.C. 20461 (202) 633B33G.
SUPALEAERTARY I:SFORMATION :

Cumbenland bisin liuner Rate?

Schrdulies C(R-1-1) and Cli-?-1) werc: appreved. oll an interim basis, by the Assiotint Secretary for kesource

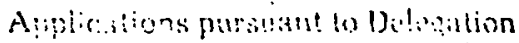

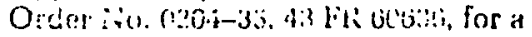
perical begitiaing July 1,1978 , and cading Jume 30 , Jigis.

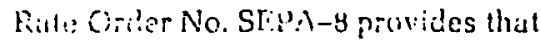
lize raite schodules shill romain in e!foc! on an interim hasis for an additional iz montis unless such preriod is aicudad (1) uniti itere or subetitute rates are confirnicd and nplauved by kERC on a finul bisis.

Issued in Wushington, D.C. Mtiy 22, 7980. Ruibist navis.

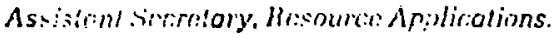

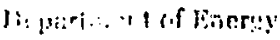

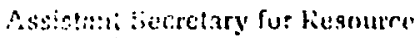

Apvinestions

In the Aaller of Southeastrirn Puwer Adninistration, Cumberland Basin Projects' Power kales; kate Order No. SEPA-8.

Order Extenciing Confirmation and Approval of Puwer hates on an Interim Basis

May 22, 1030.

Pursuant to Sections 302(a) and 301(b) of the Depurtment of Eneryy Organization Act, Fub. L. 95-91, the functiuns of the Secretury of the Interior and the federal Power Comunission uruler Section 5 of the Fluod Control Act of 19.14, 16 U.S.C. 825s, relating to the Southeastem Power Administration (SFPA) were transferred to and vested in the Secretary of Energy. By Delcgation Order No. 0204-33, effective Jonuary 1, 1979. 43 FR 60036 (December 28, 1978), the Secretary of Energy diclegated to the Assistant Secretary for Resource Applications the authority to develop power and transmission rates, acting by and through the Administrator, and to confirm. approve and place in effect such ratcs on an interim besis and delegated to the Federal Energy Regulatory Commission (FERC) the authority to confirm and approve on a final basis or to disapprove rates developed by the Assistant Secretary under the delegation. This Rate order is issued pursuant to the delegation to the Assistant Secretary.

\section{Background}

On May 22, 1978, the Assistant Sccretary for Resource Applications issued Rate Order No. SEP $\wedge-4$ confirming and approving on an interim basis, as of July 1,1978, Wholesale Power Rete Schedules CR-1-D and CR-2-D, applicable to power from the Cumberland liasin I'rojects, Tennessee and Kentucky. Rile Schedule CR-1-D applies to the Tenncssee Valley Authority (TVA) and consists of an Annual Charge paid in monthly increments reduced by credits for power retitined and sold to custorners outsirle the IVA dis.a. Hate Schedule CR-Z-D applies to retained peaking power and/or standby power sold to Big Rivers Electric Corporation; Inciiana Statewide Rural Electric Couperative. Incorporated. Hoosier Energy
Division; Southern Illinois Power

Couperative: and kiast Kentucky Puwer Conperative and delivered at the Cunberlaus Projects or TVA interconnection poirts. These rate schedules were to remitin in effect

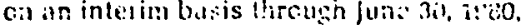
unless stuh purici wio extcaded or watlil FERC confirmed and alproved thern or substiluic rote scheriutes cn a final hasis.

Thest: rate :sehetiuless iogether wi!l an April i979 Kepayment stueiy and other supporting data. copies of a transcript of a pujlic meeting and applicalule pover contracts. Were submilted to FEKC with ti: requisest that the rate schedules be cunlirmed and approved on a final basis.

\section{Discussion}

Becesuse ot the extroopdinary mumba: is Fedeli:i puwer rutí actions suimitted for finnl opfroval winge the issuance of

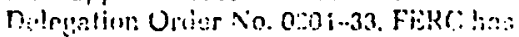

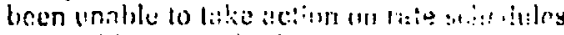

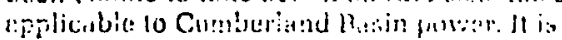
necersary. therefore. for thrs $A$ ssistam Sccretary lor Resource $A$ fipliratlons 14 cxlend interim approval of the Cumbirland Busin Rate Schedules for an additinnal 1-year period.

\section{Order}

In view of the foregoing and pursuant to the authority delegated to me by the Secretary of Energy, I hereby extend confirmation and appruval on an interim basis. cffective July 1, 1940, of attached kate Schedules CR-1-D and CR-2-D. These rate schedoles shall remain in effect on an interim basis through fune 30, 1981, unjess such period is extended or until the FERC confirms and approves them or substitute rate schedules on a final basis.

Issued at Washington. D.C., this 22nd day of May 1980.

Ruth M. Davis,

Assistant Secrelary, Resource Applications.

\section{Department of Energy}

Sütbeastern Power Adminiotration

Wholesale Power Rate Schedule CR-1-D

Availability: This rate schedule shall be available to the Tennessee Valley Authority (hereinafter called TVA).

Applicobility: This rate shedule shall be applicable to electric power and energy generated at the Dale Hollow, Center Hill Wolf Creek Old Hickory. Cheatham. Barkley, J. Percy Priest, and Cordell Hull Projects (all of such projects being hereafter called collectively the "Cumberland Projects" $j$ and sold under contract between the Department of Energy and TVA.

Charocter of Service: The electric power and accompanying energy sold hereunder will be three-phase alternative current at a frequency of approximately $60 \mathrm{Hertz}$ at the outgoing terminals of the Cumberland Projects' switchyards.

Rotes: The payirents to the Department of Energy by 'TVA hereunder for availability of capacity and deliveries of energy from the Cumberland Projects are estimated to produce over a period of years en average annuil payment of $\$ 18,450,000$, which amount 
APPENDIX E

PUBLIC PARTICIPATION PROGRAM

LISTS OF TASR FORCE MEMBERS 
CITIZEN'S TASR FORCE - CAHONSBURG

1. Lewis R. Bell (Chalrman)

Mayor

Canonsburg, Pennsylvania

2. Austin J. Murphy

U. S. Congressman

22nd District

3. Frank R. Mascara

Chairman

Washington County Commissioners

4. Janis C. Dunn

local property owner

Canonsburg, Pennsylvania

5. Agnes Engel

President

United Citizens Awareness to Rariation Exposure

6. David W. Sweet

State Representative

7. J. Barry stout

State Senator

46th District

8. Thomas N. Gerusky

Director

Bureau of Radiation Protection

Pennsylvania Department of Environmental Resources 


\section{CITIZEN'S TASR FORCE - DURANGO}

1. Mr. Don whalen (Chairman)

Fort Lewis College

1911 Delwood Avenue

Durango, Colorado 81301

2. Mr. Robert Hatfield (Vice Chairman)

City of Durango

Durango City Council

$3393 \mathrm{rd}$ Avenue

Durango, Colorado 81301

3. Mr. Herbert M. Campbell, II (Member)

Vice President \& Secretary

Ranchers Exploration \& Development Corp.

1776 Montano Road, NW

Albuquerque, New Mexico 87107

4. Mr. Jackson Clark (Member)

Durango Chamber of Commerce

P.O Box 717

Durango, Colorado 81301

5. Mr. Bruce Kirschemmann (Member)

Southwest Bar Association

Gradens Building

Durango, Colorado 81301

6. Dr. Scott McCaffrey (Member)

Citizens for Safe Tailings Management

1072 County Road 214

Dur ango, Colorado 81301

7. Dr. F. M. Murray (Member)

Southwest Medical Society

1800 East 3 rd Avenue

Durango, Colorado 81301

8. Mr. R. T. Scott (Member)

County Commissioner

1060 2nd Avenue

Durango, Colorado 81301

9. Mr. Jasper A. Welch III, Manager

Dur ango Chamber of Commerce

P. O. Box 2587

2301 Main Avenue

Durango, Colorado 81301 
CITIZEN'S TASR FORCE - SALT IARE CITY

1. Larry Anderson (Chairman)

Director, Bureau of Radiation

and Occupational Health

2. Emil Meyer (Member)

Salt Lake City Suburban

Sanitary District 1

3. Jim Davis (Member)

Mayor, South Salt Lake City

4. Gregg Goodwin (Mombor)

Salt Lake City-County

Intergovernmental Relations

5. Paula Trinoskey (Member)

Salt Lake City-County

Health Department 
APPENDIX F

INPUT FROM STATES AND INDIAN TRIBES 


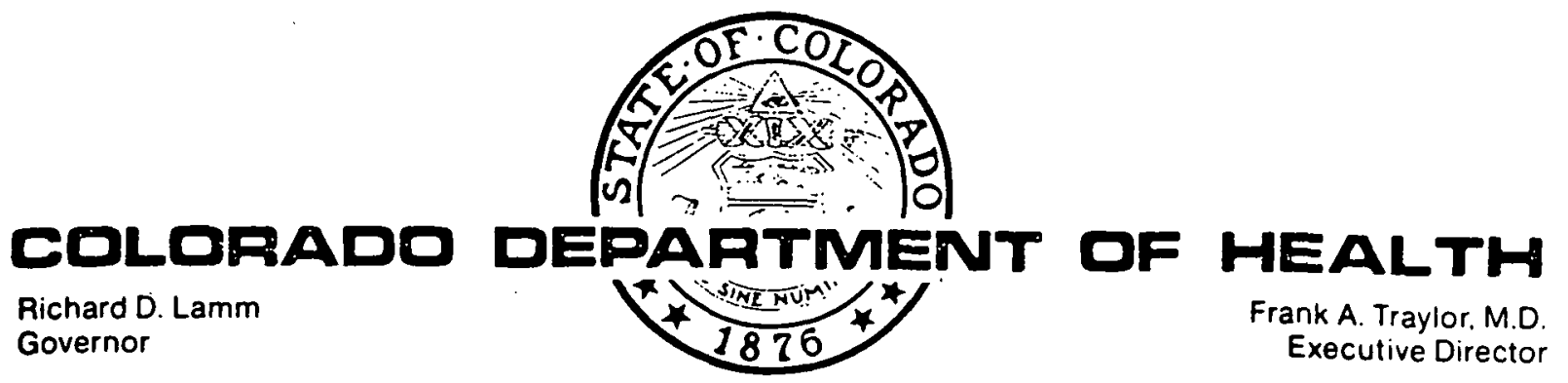

August 22, 1980

Richard H. Campbell, Project Manager

Uranium Mill Tailings Project Office

U.S. Department of Energy

Albuquerque Operations Office

P. 0. Box 5400

Albuquerque, New Mexico 87115

Dear Mr. Campbe11:

In response to your letter dated August 15, 1980, requesting Colorado's input to the annual report to Congress on UMTRAP, the following is provided:

Colorado has passed legislation in 1979 authorizing the State to participate In the program. During the 1980 legislative session limited funds were authorized for candidate disposal site investigations for the Durango pile, rights of access acquisition for DOE and its contractors, and property acquisition options for disposal sites.

The Colorado Geological Survey will convene a Colorado Department of Health appointed committee to narrow the list of candidate sites down to a most sultable list of three or four proposed disposal sites, including reprocessing capability from data available from numerous sources. The three or four most suitable sites will then be studied in detail by DOE contractors for inclusion into the DOE EIS.

Comments have been provided to EPA by Colorado on their proposed clean-up criteria.

Citizens task forces have been established by several communities in Colorado to provide public input during the program formative stages. These include Durango and Grand Junction. Discussions have been held with community leaders In Gunnison and Naturita with regard to citizens input mechanisms. 
Richard H. Campbe1l, Project Manager

August 22, 1980

Page 2

Several meetings of the Durango Task Force have been attended by Colorado representatives.

Because of concern for the interim stabilization of the Durango plles (grass planted directly on taflings to prevent serious wind erosion), DOE did proFide a contractor's consultation with the State licensee owner of the pile. The result of this effort Indicated that continued maintenance of the grass cover was the appropriate method and that other methods were not cost effective or impractical for the Interim period.

DOE contractors furing the investigations on the various Colorado plles have caused concern for the disturbance of the inplace stabilization and securficy existent at the sites. Action has been taken to repa1r the damages and to preclude reoccurrences of poor practices on the part of the contractors. Their cooperation has been appreciated.

To date, no formal negotiations have been made or proposed on the Cooperative Agreement between Colorado and DOE as required by UMTRCA, Part I. : Several meetings have been held between State and federal officials with.regard to various program operational matters.

Response to a number of proposals for tallings disposal and reprocessing have been received, acknowledged and forwarded to DOE/ALO.

Colorado has been informally notified that DOE in the near future will be providing instrumentation to Colorado for distribution (loan) to local government to preclude new construction on contaminated properties.

Coordination was provided between DOE and the State on activities of various Investigations being conducted at the sites with the local government representatives.

No action has been taken to Colorado's knowledge on off-site properties contaminated with mill tailings where current data indicates levels of radiation in excess of the guidance provided by EPA. Some of these sites individually are more hazardous to the occupants than the tailings piles are hazardous to the general public.

Colorado has recommended that several other sites be designated under UMTRCA. Due to the legal definitions these sites have been deferred to FUSRAP. Concern is expressed by Colorado that the leg1slation drafted by DOE/OMB w11 not include these sites when records available from USGS, NRC, and others indicate to the contrary. To some it appears the federal government has conveniently lost some records. 
Richard H. Campbell, Project Manager August 22, 1980

Page 3

I trust this is the kind of information that you (DOE) might wish to include in the report to Congress in one form or another.

If I may be of further service, please advise.

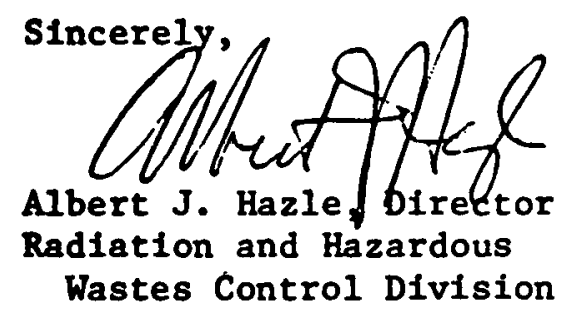

AJH: bjw

cc: Frank Traylor, M.D.

Governor's office

Robert Arnott 
Richard H. Campbel1, Project Manager Uranium Mill Tailings Project Office Department of Energy

Albuquerque Operations Office

P.0. Box 5400

Aihuquerque, New Mexico 87115

Dear Mr. Campiell:

In reference to your letter of August 15, 1980 requesting a summary of our activities in 1980 concerning the Uranium Mill Tailings

Radiation Control Act of 1978, we have the following comments:

We have contacted owners of the Lowman mill site for their input on options for remedial action.

We have advertised in regional newspapers for identification of offsite properties that may be included in the cleanup operation. We have identified nine off-site properties for survey.

We have written to Dr. Bill Mott requesting a legal opinion on legalities of site ownership in preparation for transfer of the Lowman mill site ownership.

Five of the off-site areas have been surveyed for radioactive content by Argonne National Labs. Two areas have been identified for further studies. One of these areas has been designated for inclusion into the remedial action plan.

The state has assisted Politech Inc. in identifying concerned groups of citizens in the Lowman area.

An issue analysis is being prepared for the state Health \& Welfare administration on actions needed for obtaining agreements with DOE on Lowman.

It is difficult to predict with any accuracy actions that will occur from September to November. However, we anticipate completion of the evaluation of the remaining sites near Lowman, acquisition of the Lowman property, and clarification of the steps in obtaining the agreement with the U.S. Department of Energy. We would like to know what the time table will be of anticipated needs in the future. 
Richard H. Campbell, Project Manager

August 20, 1980

Page 2

Please keep us informed of any actions that the state should be initiating.

Sincerely,

Tret 0 T'underbury

Robert D. Funderburg

Manager

Radiation Control Section

$f d n$ 


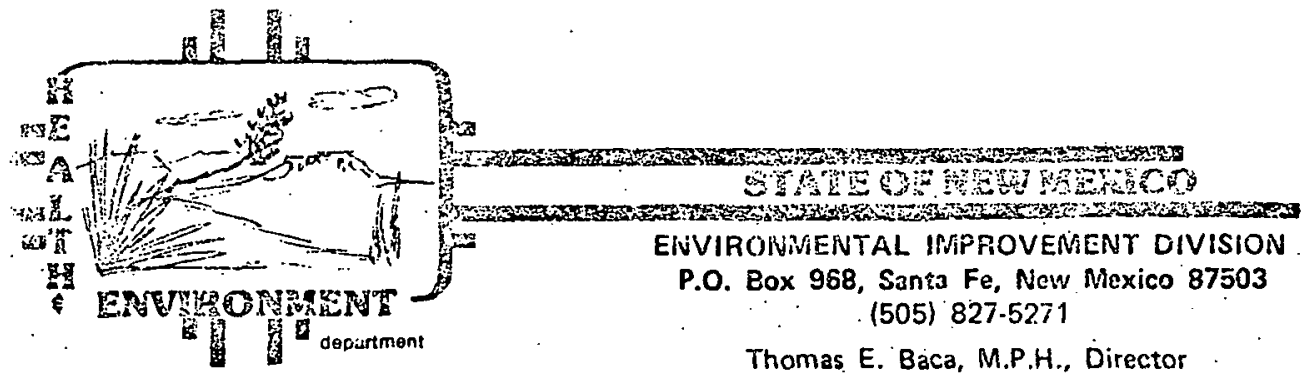

RADIATION PROTECTION BUREAU
Bruce King

GOVERNOR

George S. Goldstein Ph.D. SEORETARY

LarnJ. Gordon, M.S., M.P.H. DEPUTY SECRETARY

October 7, 1980

Richard Campbe11, Project Mañager

Uranium Mill Tailings Project Office

Department of Energy

Albuquerque Operations office

P. 0. Box 5400

Albuquerque, NM 87115

Dear Mr. Campbel. T:

In response to your letter of August 15, 1980 concerning New Mexico's participation in the Uranium Mili Tailings Remedial Action, we submit the following comments:

A. New Mexico provided assistance to your office in arrangements for site visits to the 01d Phillips Pile, Ambrosta Lake.

B. Our office briefed the New Mexico Legislative Finance Committee ull July 14, 1980, on Title I Uranium Mill.

Tailings Radiation Control Act of 1978 and action taken by DOE and the State. Included briefing items were possible DOE Research and Development at the 01d Phillips site and the costs expected to be funded by New Mexico.

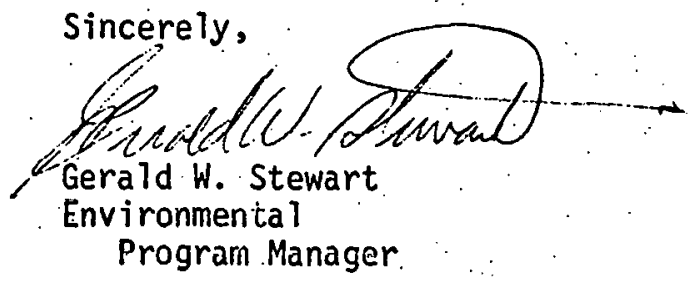

EQUAL OPPORTUNITY EMPLOYER 
Environmental Control Division of

Environmental Engineering

Missouri Office Building

1200 Missouri Avenue

Bismarck, North Dakota 58505

Dana K. Mount, P.E. Director

(701) 224-2348

September 9,1980
Narth Dakata State

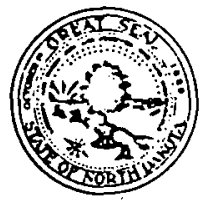

Joan G. Babbott, M.D. State Health officer (701)224-2372

Gene A. Christianson, P. Chief

Environmental Control (701) 224-2373

\section{Department of Afealth}

Mr. Richard H, Campbell

Project Manager

Uranium Mill Tailings

Project office

Department of Energy

Albuquerque Operations Office

P.O. Box 5400

Albuquerque,' New Mexico 87115

Dear Mr. Campbell:

Referenced is your letter dated August 15, 1980, requesting a summary of this Department's participation from January 1 - November 30, 1980, in the program relating to Uranium Mil.l Tailings Remedial Actions.

From the period January $I, 1980$ through the present date, this Department has been corresponding with Dr. William Mott's office and your office in reydrd to the two sites in North Dakota, Sowman and Belfield, which have been designated as candidates for remedial action.

In February of this year, this Department reviewed a preliminary health impact evaluation prepared for Bendix Field Engineering Corporation, dated October 17, 1979, by Ford, Bacon \& Davis Utah, Inc. regarding the Bowman and Belfield sites. We addressed our comments to Dr. Mott's office.

Also, in February, Dr. Mott requested our assistance in collectins environmental samples from the two sites for laboratory analyses for radionuclides of terrestrial origin and for toxic substances such as molybdenum, selenium and arsenic. During the month of June, the samples were collected and sent in to Dr. Haywcod, Health and Saftety Research Division, Oak Ridge National Laboratory. The samples were collected at the same time Ford, Bacon \& Davis Utah, Inc. were gathering data at Bowman and Belfield for a detailed engineering assessment report of the sites. Before the on-site data gathering process took place, the appropriate local government authorities were notified by letter of the FBDU scheduled site visits.

In July, this Department reviewed and commented, by request from Dr. Mott, on the accuracy of the site descriptions and background facts identified in sections of a draft report pertaining to the state of North Dakota. 
On several occasions. this Department has met and assisted representatives of the Politech Corporation in their efforts to prepare for the UMTRA office detailed information to plan the project and to conduct an effective and responsible public participation program.

On September 9, 1980, Mr. Mark Mathews of your office, met with representatives of this Department and discussed the UMTRA Master Activity schedule, along with a few other items that would be considered in carrying out this project.

Presently, we are awaiting the results of the laboratory arialyses of the environmental samples from the sites. While the Department of Energy is making its assessment of the sites, this Department will continue to assist the DOE in any manner possible.

If you should have any questions, please feel free to contact this office.

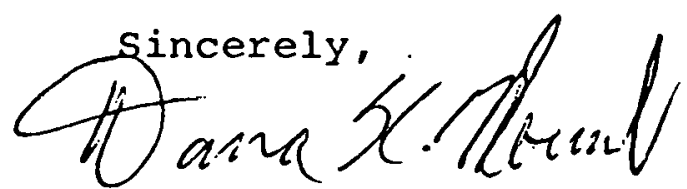

Dana K. Mount, P.E.

Director

Division of Environmental

Engineering

$\mathrm{DKM} / \mathrm{JLB}: \mathrm{ClK}$

cc: Gene A. Christianson, Chief 


\section{COMMIONWEALTH OF PENNSYLVANIA DEPARTMENT OF ENVIRONMENTAL RESOURCES}

$\therefore$ Post office Box 2063.

Harrisburg, Pennsylvania 17120

October 16,1980

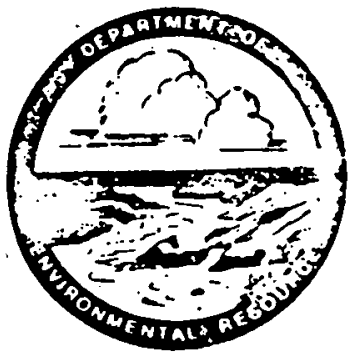

(717) $787-3720$

Richard H: Campbell, Project Manager Uranium Mill Tailings Project office U.S. Department of Energy Albuquerque Operations office P.O. Box 5400 Albuquerque, New Mexico 87115

Dear Mr. Campbell:

We are enclosing a summary report covering our activities under the Uranium Mill Tailings Radiation Control Act of 1978, P.L. 95-604 with respect to the Canonsburg Industrial Park.

If further action on our part is required, please advise accordingly.

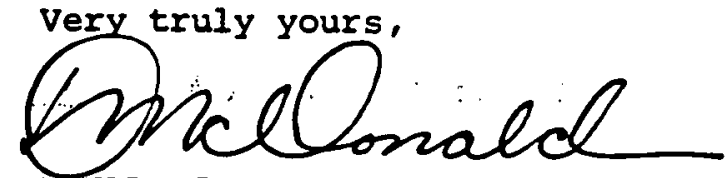

DONALD J. MCDONALD, Chief Division of Radiation Control Bureau of Radiation Protection

Enclosure 


\author{
Commonwealth of Pennsylvania \\ Uranium Mill Tailings Radiation Control Act of 1978, P.L. 95-604 \\ Summary of Activities \\ January 1,1980 through iNovember 30,1980
}

The activities performed by Pennsylvania with respect to the remedial action program at the Canonsburg Industrial Park are summarized below. This summary report is submitted for inclusion in the report required by Section 114 (a) of P.L. 95-604, Uranium Mill Tailings Radiation Control Act of 1978.

Pennsylvania has been very active in finalizing the Cooperative Agreement between the State and the U.S. Department of Energy. We have reviewed and commented on various deafl versions of the basir. agreement and its extensive appendix. The final version of the Cooperative Agreement was signed by State and Federal officials and became effective on september 5, 1980.

A Task Force comprised of local officials and interested citizens has been established by the Yennsylvauia Department of Environmental Resources to keep the public intormed on cledulp activitios at the ranonsburg Industrial Park. Members of the Task Force include the local U.S. Congressman, the local State Senator and State Representative, the Mayor of Canonsburg and the ManagerSecretary of North Strabane Township, the Chairman of the Washington County Commissioners, the owner of a designated off-site property, and the President of the United Citizens Awareness to Radiation Exposure group. The first ineeting of the Task Force is expected to be held in the fall of 1980. Additional meetings will be held throughout the duration of the cleanup activities.

The Commonwealth has investigated and identified potential depository sites in Pennsylvania for the tailings from the former processing site and the contaminated material from off-site properties. The selection of potential sites was based on a set of criteria taken from the preliminary draft of Title 10 CFR Part 61, Disposal of Low-Level Radioactive Waste and Low-Activity. Bulk Solid Waste, prepared by the Nuclear Regulatory Commission. Factors such as population density, land use, drainage, subsidence and landslide potential, ground water characteristics, location of oil and gas well, fields, and location of lineaments and zones of structural discontinuity were considered. This resulted in the selection of seven specific sites which best fit the criteria developed by the NRC. Currently, the sites are being evaluated by the Pennsylvania Department of Environmental Resources not only from a technical and scientific viewpoint but also for the social, economic and legal ramifications, their use for waste disposal may incur. 
Sntt M. Matheson

\section{Governor}

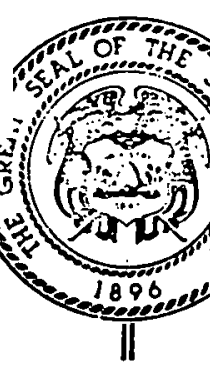

James O. Mason, M.D., Dr.P.H.

Executive Director

801-533.6111

DIVIStons

Commlinity Health Services

Envirumimentiai ilealith

F'amily Healith Services

Health Core Financing and Standards

OFFICÉS

Administrative Services Health Planning and

Policy Deuelspment

Medical Examiner

State Health Laboratory
STATE OF UTAH

DEPARTMENT OF HEALTH

DIVISION OF ENVIRONMENTAL HEALTH

150 West North Temple, P.O. Box 2500, Salt Lake C̣ity, Utah 84110

Alvin E. Rickers, Director

Room $426 \quad 801.533-6121$

September 17, 1980 533-6734

-Richard H. Campbell

Uranium Mill Tailings Office

U.S. Department of Energy

Albuquerque Operations Office

P.0. Box 5400

Albuquerque, New Mexico 87115

Dear Mr: Campbel1:

As you requested, we are providing the following information about Utâh's participating in the remedial action progran for the IIranium Mill Tailings Radiation Controi HLi:

1. The Bureau of Radiation and Occupational

Health and the Salt Lake City-County Health

Department, utilizing the 1972 Environmental

Protection Agency, gamma ground survey of

Salt Lake City, recent Depariment of Energy

contracted aerial radiation detection surveys

and public participation have investigated

an estimated 150 properties within Sa?t

Lake county. Thus far 80 of these locations

are contaminated with mill tailings from the

Vitro Uranium Mill. In addition to the

ground radiation detection surveys conducted

by the Bureau of Radiation and Occupational

Health, other environmental sampling nas

been conducted at many of these iocations.

2. Non-lapsing funding has been secured for FY

81. Approximately, $\$ 165,000$ is aváilable for

Utah's participation in Remedial Action

Progran in Salt Lake City for the Uranium

Mill Tailings Radiation Control Act.

3. In accordance with the mandate for full participation in planning for renedial actions, ard recognizing the need for coordination of remediai activilies among fedeiar, statu and 
local representatives, a Salt Lake City $\mathrm{Si} 1 \mathrm{l}$

Tailings Coordinating Task Force was estab-

lished. The Task Force is to:

a. Provide a means for coordinating plans and proposed activities regarding remedial actions for the vitro uranium mill tailings, processing site and contaminated vicinity properties.

b. Provide a forum for discussion of issues rciated to Salt Lak.e rit.y remedial actions.

c. Provide contacts for information exchange between Salt Lake City and Federal/State. representatives, including public information materials.

Representation on the Task Force includes the City and County Governments, the City of South Salt Lake, the City-County Health Department, the processing site owner, U.S. Department of Energy and the Bureau of Radiation and Occupational Health.

4. A Vitro Tailings Disposal Site Selection Committee was assembled from the staff of the Uivision of Ervirurmieritai Health, State Department of Health and the Utah Geologic and Mineral Survey. The site selection committee was given the responsibility by the Governor to recommend a final disposal site for the Vitro Mill Tailings. The recommendations for a disposal site were based on "reconnaissance level" information about the physical acceptability of the sites. Eleven locations within Utah representing three significant proposals for disposal of the tailings were assessed. Recommendations and a summary of the Committee findings have been forwarded to State and Federal officiais for concurrence and action.

5. The State actively encouraged the Environmental Protection Agency to promulgate the clean-up standards for off-site tailings locations. On April 15, 1980 a news conference was held by EPA in Salt Lake City to release the draft standards.

If I can provide additional information, please feel free to contact me.

DLF : CW

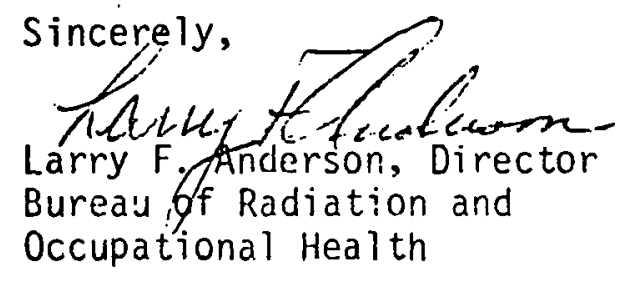


APPENDIX G

B IBL IOGRAPHY 


\section{BIBLIOGRAPHY}

1. Ford, Bacon \& Davis Utah Inc., "Phase II - Title I Engineering Assessment of Inactive Uranium Mill Tailings, Monument Valiey Site, Monument Valley, Arizona," GJT-4, March 31, 1977.

2. Ford, Bacon \& Davis Utah Inc., "Phase II - Title I Engineering Assessment of Inactive Uranium Mill Tailings, Tuba City Site, Tuba City, Arizona," GJT-5, March 31, 1977.

3. Ford, Bacon \& Davis Utah Inc., "Phase II - Title I Engineering Assessment of Inactive Uranium Mill Tailings, Durango Site, Durango, Colorado," GJT-6, November 1977.

4. Ford, Bacon \& Davis Utah Inc., "Phase II - Title I Engineering Assessment of Inactive Uranium Mill Tailings, Grand Junction Site, Grand Junction, Colorado," GJT-9, October 1977.

5. Ford, Bacon \& Davis Utah Inc., "Phase II - Title I Engineering Assessment of Inactive Uranium Mill Tailings, Gunnison Site, Gunnison, Colorado," GJT-12, November 1977.

6. Ford, Bacon \& Davis Utah Inc., "Phase II - Title I Engineering Assessment of Inactive Uranium Mill Tailings, Maybell Site, Maybe11, Colorado," GJT-11, October 1977.

7. Ford, Bacon \& Davis Utah Inc., "Phase II - Title I Engineering Assessment of Inactive Uranium Mill Tailings, Naturita Site, Naturita, Colorado," GJT-8, November 1977.

8. Ford, Bacon \& Davis Utah Inc., "Phase II - Title I Engineering Assessment of Inactive Uranium Mill Tailings, New and old Rifle Sites, Rifle, Colorado," GJT-10, October 1977.

9. Ford, Bacon \& Davis Utah Inc., "Phase II - Title I Engineering Assessment of Inactive Uranium Mill Tailings, Slick Rock Sites, S1ick Rock, Colorado," GJT-7, October 1977

10. Ford, Bacon \& Davis Utah Inc.. "Phase II - Title I Engineering Assessment of Inactive Uranium Mill Tailings, Lowman Site, Lowman, Idaho," GJT-17, December 1977.

11. Ford, Bacon \& Davis Utah Inc., "Phase II - Title I Engineering Assessment of Inactive Uranium Mill Tailings, Phillips/United Nuclear Site, Ambrosia Lake, New Mexico," GJT-13, December 1977

12. Ford, Bacon \& Davis Utah Inc., "Phase II - Title I Engineering Assessment of Inactive Uranium Mill Tailings, Shiprock Site, Shiprock, New Mexico," GJT-2, March 31, 1977. 
13. Ford, Bacon \& Davis Utah Inc., "Phase II - Title I Engineering Assessment of Inactive Uranium Mill Tailings, Lakeview Site, Lakeview, Oregon," GJT-18, December 1977.

14. Ford, Bacon \& Davis Utah Inc., "Engineering Evaluation of the Former Vitro Rare Metals Plants, Canonsburg, Pennsylvania," FBDU 230-002, July 1979.

15. Ford, Bacon \& Davis Utah Inc., "Phase II - Title I Engineering Assessment of Inactive Uranium Mill Tailings, Falls City Site, Falls City, Texas," GJ'T-16, December 1977.

16. Ford, Bacon \& Davis Utah Inc., "Phase II - Title I Engineering Assessment of Inactive Uranium Mill Tailings, Green River Site, Green River, Utah," GJT-1, December 1977.

17. Ford, Bacon \& Davis Utah Inc., "Phase II - Title I Engineering Assessment of Inactive Uranium Mill Tailings, Mexican Hat Site, Mexican Hat, Utah," GJT-3, March 31, 1977.

18. Ford, Bacon \& Davis Utah Inc., "Phase II - Title I Engineering Assessment of Inactive Uranium Mill Tallings, Vitro Site, Salt Lake City, Utah," April 30, 1976.

19. Ford, Bacon \& Davis Utah Inc., "Phase II - Title I Engineering Assessment of Inactive Uranium Mill Tailings, Spook Site, Converse County, Wyoming," GJT-15, December 1977.

20. Ford, Bacon \& Davis Utah Inc., "Phase II - Title I Engineering Assessment of Inactive Uranium Mill Tailings, Riverton Site, Riverton, Wyoming," GJT-19, December 1977.

21. U,S, Department of Energy, Progress Report on the Grand Junction Uraniun Mill Tailings Renedial Action Program, February 1979.

22. U.S, Department of Energy, Report on Residual Radioactive Materials on Public or Acquired Lands of the United States, July I, 1979.

23. U.S. Department of Energy, Annual Status Report on the Inactive Uranium Mill Tailings Sites Remedial Action
Program, December 1979 . 